\title{
Gastropods from the Early/Middle Jurassic transition of Franconia (Southern Germany)
}

\author{
CHRISTIAN SCHULBERT \& ALEXANDER NÜTZEL
}

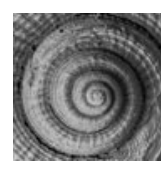

A rich gastropod fauna is decribed from the Early/Middle Jurassic boundary (late Toarcian/early Aalenian) of Franconia (N Bavaria, South Germany). It comprises 35 nominate species and additional 9 species are treated in open nomenclature. With a few exceptions, the studied material comes from the Jurensismergel and the Opalinuston formations of the Mistelgau clay pit near Bayreuth. These sediments represent marine soft bottom environments. Gastropods are the most diverse and the most abundant group of the benthic communities in the Mistelgau clay pit. Bivalves, ophiurid and crinoid ossicles as well as foraminifera are also abundant. Among the bivalves, the paper pecten Bositra buchi and the inoceramid Pseudomytiloides dubium are especially abundant. Most of the members of the benthic fauna are small $(<15 \mathrm{~mm})$ or even minute. Only the bivalve Pseudomytiloides dubium, some of the vetigastropods (e.g., Pleurotomarioidea) and the family Gordenellidae (Turritelloidea and Proacirsa) attain a size larger than $2 \mathrm{~cm}$. However, these large species are rare. The most abundant gastropods are the caenogastropod species Coelodiscus minutus and Toarctocera subpunctata. Both species are especially abundant in the lowermost portions of the sampled section. Towards the Aalenian, an increase in diversity can be observed. This reflects recovery from the late Pliensbachian/early Toarcian extinction event. This event was connected with early Toarcian anoxia in Central and Northern Europe including black shale deposition (Posidonienschiefer). The studied gastropod fauna lived during still impoverished but improving environmental conditions. The relatively high diversity and abundance of the benthos suggest aerobic or dysaerobic conditions, however with possible fluctuations of oxygen concentrations. The fauna was also constrained by soft bottom conditions. 12 species are described as new: Mistelgauia monarii, Hummelgauia microstriata, Jurilda zapfi Schulbert, Nützel \& Gründel sp. nov., Franconicilda juliae, Carinathilda? dieneri, Conusella convexa, Cossmannina eggmaieri, Sinuarbullina? mistelgauensis, Striactaeonina waltschewi Schulbert, Nützel \& Gründel sp. nov., Striactaeonina richterorum Schulbert, Nützel \& Gründel sp. nov., Parvulactaeon imprimum Schulbert, Nützel \& Gründel sp. nov. and Parvulactaeon inclinatum Schulbert, Nützel \& Gründel sp. nov. Three genera are described as new: Hummelgauia, Mistelgauia and Franconicilda. The family Coelodiscidae Gründel \& Nützel fam. nov. is described as new based on the probably holoplanktonic gastropod genus Coelodiscus. - Key words: Gastropoda, Toarcian, Aalenian, Jurassic, Germany.

SCHULBERT, C. \& NÜTZEL, A. 2013. Gastropods from the Early/Middle Jurassic transition of Franconia (Southern Germany). Bulletin of Geosciences 88(4), 723-778 (35 figures). Czech Geological Survey, Prague. ISSN 1214-1119. Manuscript received February 6, 2013; accepted in revised form June 25, 2013; published online September 11, 2013; issued October 31, 2013.

Christian Schulbert, GeoZentrum Nordbayern, Fachgruppe Paläoumwelt, Friedrich-Alexander Universität Erlangen-Nürnberg, Loewenichstraße 28, 91054 Erlangen, Germany; christian.schulbert@fau.de • Alexander Nützel, SNSB-Bayerische Staatssammlung für Paläontologie und Geologie, Department of Earth and Environmental Sciences, Palaeontology \& Geobiology, Geobio Centre LMU, Richard-Wagner-Str. 10, 80333 München, Germany; a.nuetzel@lrz.uni-muenchen.de

Early and Middle Jurassic dark shales of Franconia (N Bavaria) commonly yield abundant gastropods. At some locations, gastropods form even the most abundant fossil group of the benthos. Therefore, gastropods must play an important role in the reconstruction of benthic palaeocommunities and palaeoenvironmental reconstructions. The study of Liassic and early Middle Jurassic gastropod faunas is also crucial for our understanding of the end-Triassic and Toarcian mass extinction events.
Compared with other regions, the Toarcian/Aalenian gastropod fauna of Germany is relatively well-known. The present study reports 44 gastropod species of Toarcian/Aalenian age including 9 species in open nomenclature. With a few exceptions, the material comes from a single clay pit near the village Mistelgau near Bayreuth in Upper Franconia (Oberfranken), South Germany (Fig. 1). This assemblage represents the most diverse Toarcian/Aalenian gastropod fauna from a single outcrop ever reported from Central Europe. 


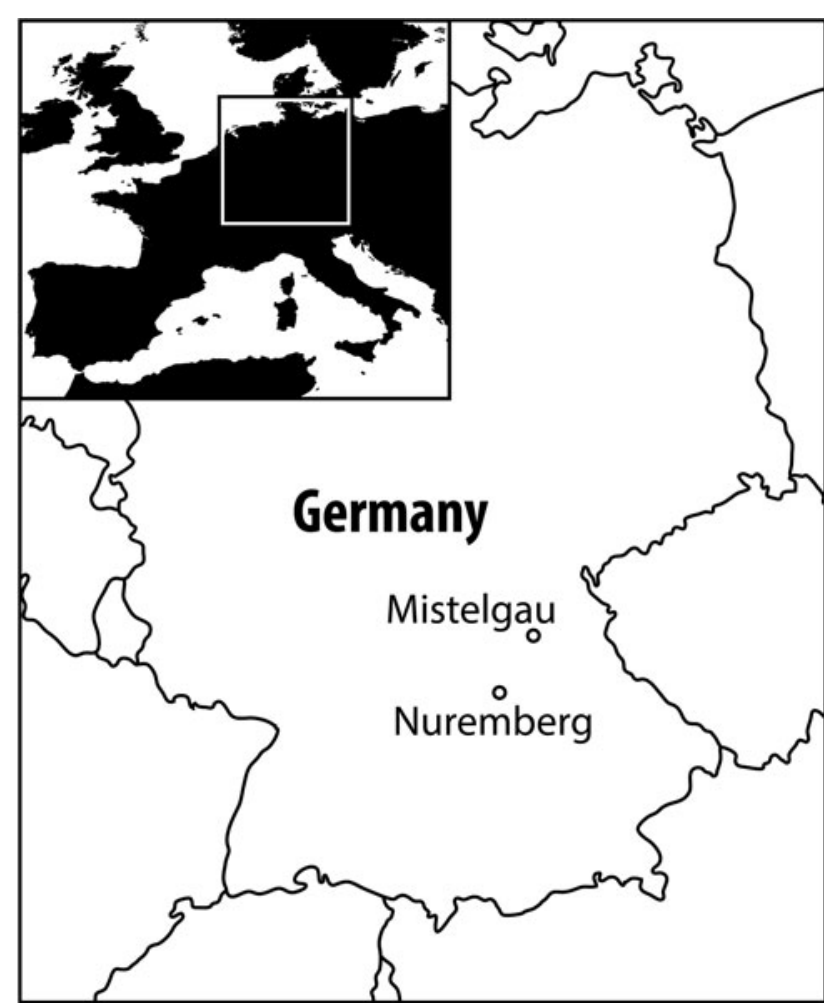

Figure 1. Geographical position of the village Mistelgau in Southern Germany.

The Mistelgau clay pit is known for its abundant and commonly well-preserved fossils. Numerous specimens of various fossil groups have been documented in the last decades. Spectacular fossils like ichthyosaurs and abundant pyritic steinkerns of ammonites are known from Mistelgau (e.g., Heller 1953, 1956; Wild 1971; Schlegelmilch 1973; Schulbert 2001). In contrast, the micro- and meiofauna of Mistelgau is more or less unknown in the literature. Merely ophiuroid ossicles (Kutscher 1996) and some gastropod species (Gründel 1998a, 1999a, 2005a; Schulbert \& Nützel 2009) have been reported so far.

Previously, Toarcian/Aalenian gastropods from Franconia were studied by zu Münster (in Goldfuss 1844) and by Kuhn (1935). Kuhn (1935) reported 47 Toarcian/Aalenian gastropod species from various locations in Franconia. Some of these species are poorly known due to poor preservation or documentation. Brösamlen (1909) reported 12 species from this time interval from Swabia (Baden-Württemberg, SW Germany). Most of these species are also present in Franconia. Klöcker (1966) reported four gastropod species from the Toarcian/Aalenian near Freiburg in Baden Württemberg. Gründel et al. (2011) reported 23 species from Geisingen (Swabia, Baden-Württemberg), most of them in open nomenclature. Etter (1990) listed six species from the Aalenian of N Switzerland; most of them are also present in Mistelgau. Schröder (1995) and Gründel (2007a) reported about 30 gastropod species from the

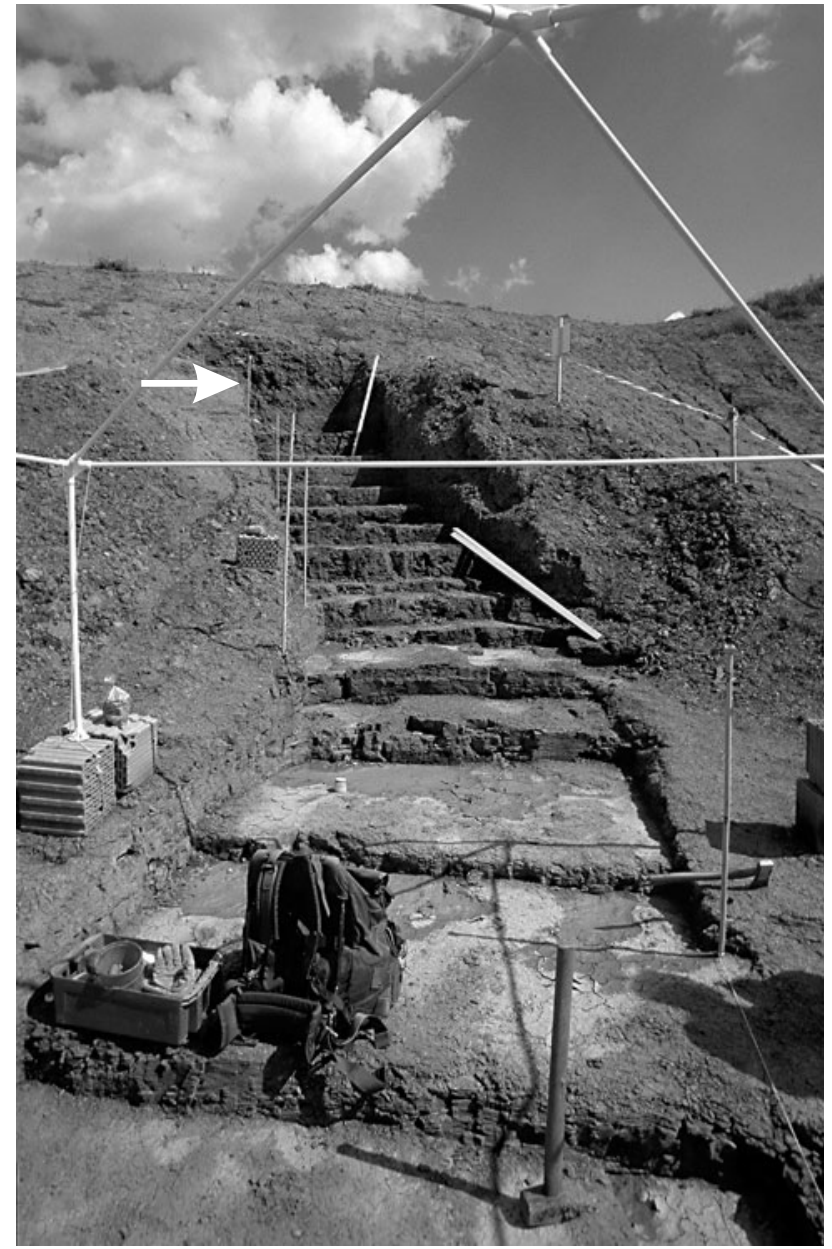

Figure 2. Upper part of the excavation site in the Mistelgau clay pit during the field campaign 1999. Sediment was excavated at $10 \mathrm{~cm}$ intervals from an area of 2 by 2 metres. Sediment samples of about $2 \mathrm{~kg}$ were also taken at $10 \mathrm{~cm}$ intervals throughout the whole section. White arrow marks the $0 \mathrm{~m}$ horizon (Lytoceras bed) at which the excavation started; the evcavated section from the lowermost level (foreground) to the $0 \mathrm{~m}$ horizon (Lytoceras bed) comprises about $4.5 \mathrm{~m}$ (see Fig. 3).

Toarcian/Aalenian of Northern Germany. Several of these species are shared with South Germany.

\section{Geological setting}

Nearly all of the studied gastropods come from a clay pit near the village Mistelgau near Bayreuth in Upper Franconia (Oberfranken), South Germany (Fig. 1). Some are from unhorizonted surface collections. However, the great majority of the specimens was recovered by an excavation which covered a section that reaches from the late Toarcian Jurensismergel Formation (or Subformation) to the early Aalenian Opalinuston Formation (Lias $\xi$ to Dogger $\alpha$ sensu Quenstedt). The biostratigraphy of the section exposed at Mistelgau was clarified in detail by Schulbert (2001) using ammonites. 
The sediments in the Mistelgau clay pit comprise three lithological formations: The Amaltheenton Formation (late Pliensbachian), Posidonienschiefer Formation ("Posidonia Shale", early Toarcian) and Opalinuston Formation (late Toarcian/early Aalenian); the latter includes the Jurensismergel-Subformation at its base. The gastropods of this study derive from the Jurensismergel and the Opalinuston formations. These units consist of marly clay stones, which were deposited in the German Basin at the Liassic/Dogger transition. For some years, the upper Amaltheenton Formation (late Pliensbachian) was exposed as lowermost unit in the Mistelgau clay pit. It consists of dark grey and monotonous clay stones. Fossils from this unit were not studied here. The Posidonienschiefer Formation (early Toarcian) is characterized by its high concentration of hydrocarbons in slate like, laminated carbonates and marls. These sediments (black shales) were deposited under oxygen depletion and are largely devoid of benthic fauna. The topmost carbonate bank of the Posidonienschiefer Formation represents the well-known belemnite-battlefield. This horizon is widespread in South Germany and consists of millions of belemnite rostra. This mass accumulation of belemnite rostra is the result of widespread condensation due to bottom currents in the German Basin. The belemnite-battlefield yields also abundant vertebrate remains, especially ichthyosaur remains. The late Toarcian and early Aalenian sediments above the belemnite bed yielded the gastropods studied here. They were recovered from a section comprising the ammonite zones of Haugia variablis to Leioceras opalinum (Schulbert 2001) (Figs 2, 3). The exposed Toarcian/Aalenian deposits above the belemnite bed are homogenous shales i.e., clay stones and marls.

\section{Depositional environment and fauna}

The Jurensismergel Subformation (Jurensis Marl) and the Opalinuston Formation (Opalinum Clay) represent typical marine epicontinental basin sediments (e.g., Etter 1995). The Opalinuston Formation was deposited in the South German Basin and is also present in N Switzerland (Ziegler 1988, 1990; Etter 1995, fig. 1). This basin is situated between Massif Central to the West, the Rhenish Massif to the North and the Bohemian Massif to the East. Those

Figure 3. Stratigraphic distribution of the most abundant and some additional gastropod species which were recovered stratified from the excavated section in the Mistelgau clay pit (Fig. 2). The section comprises the ammonite zones of Dumortieria levesquei, Cotteswoldia aalensis and Leioceras opalinum and thus also the boundary between the chronostratigraphic units of the Toarcian (Lias, Early Jurassic) and the Aalenian (Dogger, Middle Jurassic). The excavation started from the Lytoceras bed (metre 0) downward but was afterward extended into the overlying sediments.

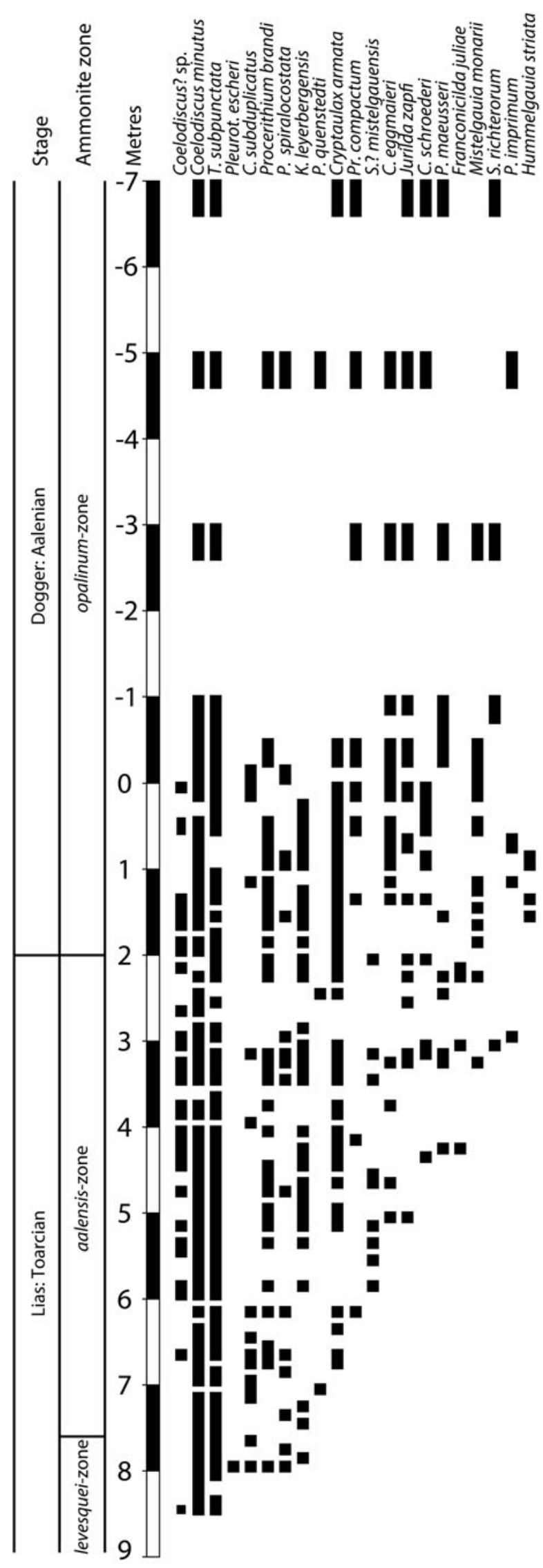


highs were areas of non-deposition and were land during the late Early Jurassic and early Middle Jurassic. The Jurensismergel and Opalinuston of Franconia were deposited west of the Bohemian Massif and Mistelgau was situated about $50 \mathrm{~km}$ offshore. There were open seaways to the boreal realm and to the Tethys Ocean. The uniform clayey and marly sediments exposed in the clay pit near Mistelgau and other parts of Franconia suggest mostly calm conditions at depth below storm wave base as was also suggested for the Opalinuston in N Switzerland by Etter (1995). Deposition took place under fully marine conditions as is indicated by abundant ammonites and ophiuroid ossicles. The fauna is rich and diverse although most benthic species area small. The benthic macro- and mesofauna consists mainly of gastropods, bivalves, scaphopods, small solitary corals and rare crustaceans. There is also a rich microfauna of foraminifera and ostracodes. The gastropod Coelodiscus minutus and especially the bivalve Bositra buchi are superabundant. Their mode of life is disputed (planktonic vs. benthic, see discussion below). Etter $(1995,1996)$ interpreted both species as benthic opportunists while others advocate a planktonic mode of life. The soft bottom conditions with soupy substrates and oxygen availability (fully aerobic to dysaerobic) constrained diversity and composition of the benthic faunas in the Jurensismergel and Opalinuston Sea.

\section{Repository}

The material is housed in the Bayerische Staatssammlung für Paläontologie und Geologie, München under the number BSPG 2011 XLII. A few specimens are housed in the Urwelt-Museum Oberfranken, Bayreuth and in the Naturkundemuseum Coburg.

\section{Systematic palaeontology}

Subclass Vetigastropoda Salvini-Plawen, 1980

Superfamily Pleurotomarioidea Swainson, 1840

Family Pleurotomariidae Swainson, 1840

\section{Genus Laevitomaria Conti \& Szabó, 1987}

Type species. - Pyrgotrochus? problematicus Szabó, 1980, Bajocian, Bakony Mountains, Hungary.

Laevitomaria? cf. subtilis (zu Münster in Goldfuss, 1844) Figure 4A-D

cf. *1844 Pleurotomaria subtilis sp. nov. - Zu Münster in Goldfuss, p. 71, pl. 185, fig. 3.

cf. 1935 Pleurotomaria subtilis. - Kuhn, p. 129, pl. 9, fig. 27, pl. 10, figs 15,41 .
Material. - One specimen from Neusig near Waischenfeld (South Germany), Urwelt-Museum Oberfranken, Bayreuth, BT 006295.00.

Description. - Shell broadly trochiform; specimen comprises somewhat more than eight whorls (including protoconch), $2.8 \mathrm{~cm}$ high and $2.6 \mathrm{~cm}$ wide; whorls slightly angulated somewhat below mid-whorl where broad selenizone is situated; whorl steeply inclined below angulation and less inclined above angulation forming a broad ramp; whorls with dense reticulate ornament of numerous fine axial, collabral threads (strengthened growth lines) and spiral threads; axial threads curve backward (abapertural) at borders of selenizone; axial threads prosocline between selenizone and adapical suture; axial threads prosocyrt between selenizone and abapical suture; on last preserved whorl, 6 spiral threads present below selenizone and about ten above selenizone; selenizone flush, bordered by two spiral threads; two additional spiral threads present on selenizone; base convex with rounded angular edge at junction with whorl face; base somewhat concave near edge and convex towards middle of basal whorl; base with small umbilicus; base ornamented with somewhat strengthened sigmoidal growth lines and numerous relatively broad spiral cords; protoconch comprises about one whorl, seemingly smooth, but somewhat corroded.

Remarks. - The illustrations of the type specimen of Pleurotomaria subtilis given by $\mathrm{zu}$ Münster in Goldfuss (1844, pl. 185, fig. 3) and Kuhn (1935) show that this specimen has a lower spire and is somewhat more gradate than the present specimen. However, the type seems to be deformed. Among the species resembling the specimen at hand, Laevitomaria? cf. subtilis seems to be the only one in which the selenizone is positioned at the angulation of the whorl face. Pleurotomaria singularis Sieberer, 1907 also resembles the present specimen but has a lower spire, a more gradate outline and a coarser spiral ornament (holotype BSPG AS I 1565). The holotype of Pleurotomaria subdecorata zu Münster in Goldfuss, 1844 (BSPG AS VII 1455) is similar but has a stronger angulation and the selenizone lies distinctly below this angulation. Laevitomaria? cf. subtilis resembles P. quenstedti but is more high-spired, the whorls are not as strongly angulated (step-like) and the selenizone is situated at the angulation. The position of the selenizone and the weak angulation could suggest that Laevitomaria? cf. subtilis represents a species of the genus Bathrotomaria Cox, 1956. However, Bathrotomaria has usually a much more pronounced angulation. The type species of Laevitomaria, L. problematica (Szabó, 1980) is distinctly more slender and shows no or a very faint angulation of mature whorls. Thus, the present specimen is placed in this genus only tentatively. 


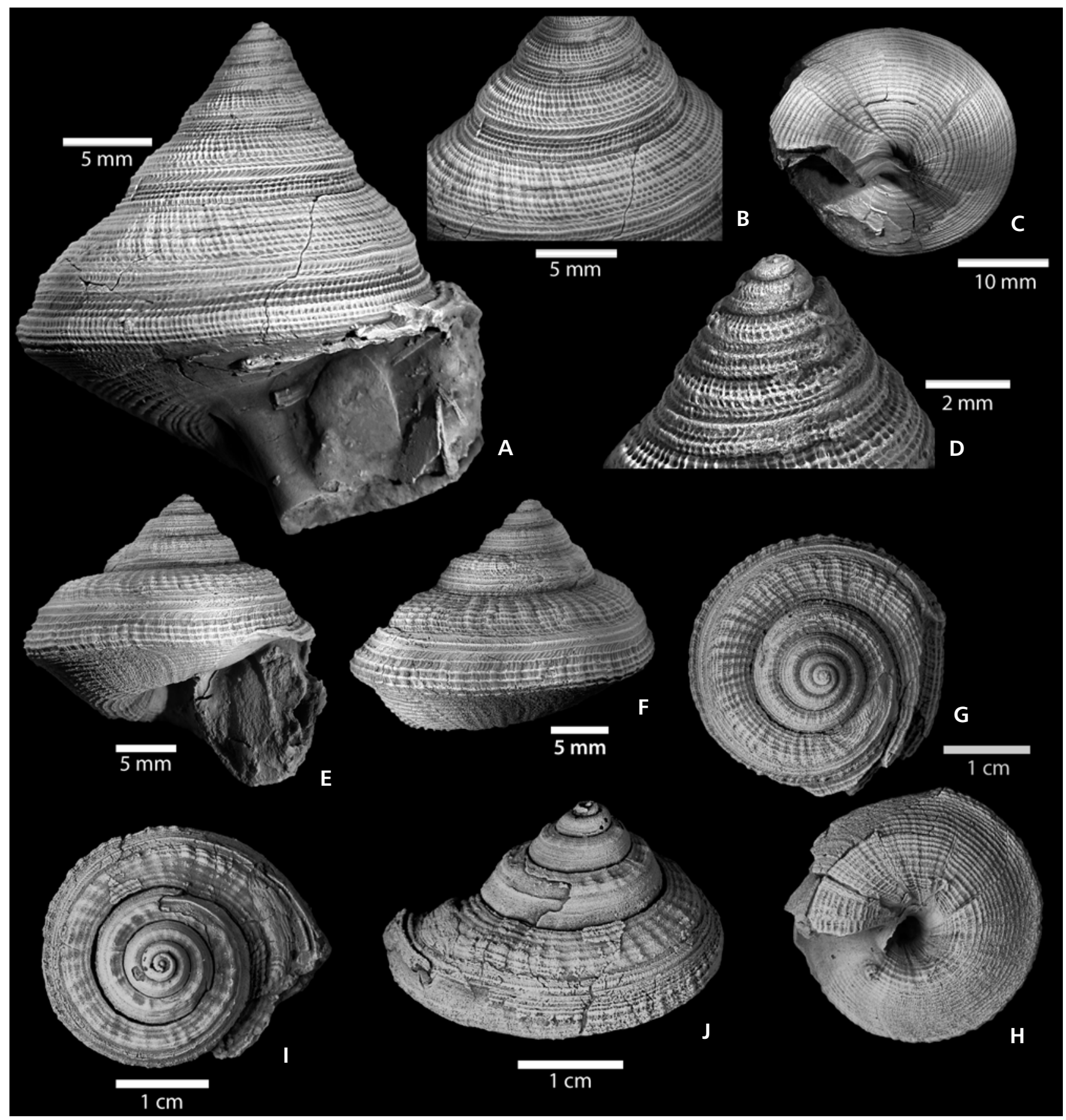

Figure 4. A-D - Laevitomaria? cf. subtilis (zu Münster in Goldfuss, 1844), Urwelt-Museum Oberfranken, Bayreuth, BT 005279, Neusig. - E-J - Pleurotomaria quenstedti Goldfuss, 1844, Mistelgau, surface collection; E-H - BSPG 2011 XLII 219; I, J - BSPG 2011 XLII 220.

A number of middle/late Liassic pleurotomariids have been described from Franconia, which closely resemble each other e.g., Laevitomaria? cf. subtilis, Pleurotomaria singularis, $P$. subdecorata, and $P$. quenstedti. They differ mainly in details of the ornament and the situation of the selenizone. At this point it is unclear whether some of these taxa represent synonyms.
Occurrence. - Early Aalenian.

\section{Genus Pleurotomaria Defrance, 1826}

Type species. - Trochus anglicus Sowerby, 1818; neotype from the middle Lias of South Petherton near Ilminster, Somerset, England, Official List, Opinion 582, 1960: 276. 


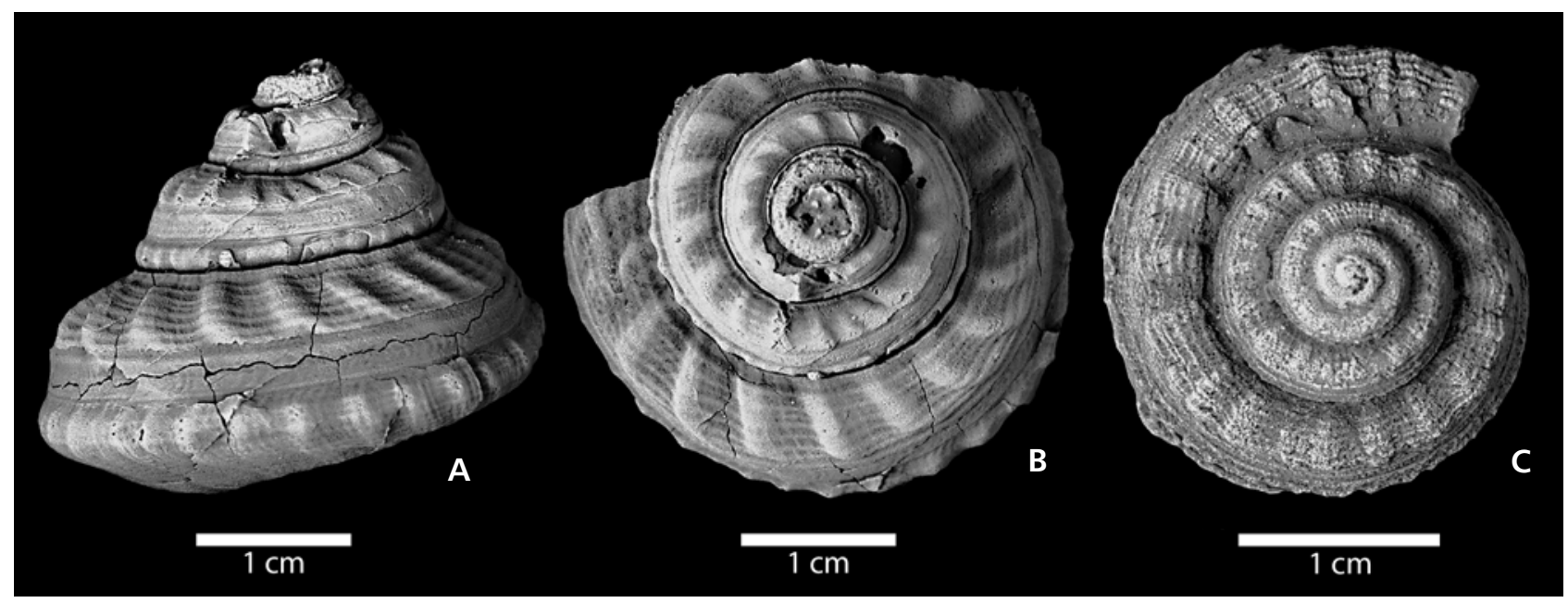

Figure 5. Pleurotomaria escheri Goldfuss, 1844, Mistelgau, surface collection. • A, B - BSPG 2011 XLII 221. • C - BSPG 2011 XLII 222.

\section{Pleurotomaria quenstedti Goldfuss, 1844}

Figure 4E-J

*1844 Pleurotomaria quenstedtii sp. nov.; Goldfuss, p. 71, pl. 185, fig. 5.

non 1858 Pleurotomaria quenstedtii. - Quenstedt, p. 316, pl. 43, fig. 27.

1901 Pleurotomaria quenstedtii. - Schlosser, p. 533.

?1907 Pleurotomaria quenstedti. - Sieberer, p. 29, pl. 2, fig. 6.

1935 Pleurotomaria quenstedtii. - Kuhn, p. 127, pl. 9, figs 12, 44, pl. 10, figs 10, 21, 33.

2009 Pleurotomaria quenstedti. - Schulbert \& Nützel, p. 477 , fig. 1 .

Material. - 15 specimens from Mistelgau from surface collections, BSPG 2011 XLII 219, 220.

Description. - Shell broadly trochiform, gradate; illustrated specimens comprise about five whorls (apex missing), $2.5 \mathrm{~cm}$ high and wide; gradate whorl profile with broad, subsutural ramp; selenizone somewhat submedian on spire whorls (at about abapical third of spire whorl height), median on last whorl; selenizone bordered by two spiral threads; one spiral thread on the middle of the selenizone; selenizone appears at about second whorl; whorls ornamented with weak wave-like, prosocline axial ribs and a dense reticulate ornament of numerous fine axial threads (strengthened growth lines) and somewhat broader spiral threads; axial ribs curve backward (abapertural) at borders of selenizone; about four to six spiral cords below selenizone and about ten above selenizone; base convex with rounded angular edge at junction with whorl face; base somewhat concave near edge and distinctly convex towards middle of whorl; base distinctly umbilicated, ornamented with numerous spiral cords; protoconch unknown.
Remarks. - Pleurotomaria quenstedti is one of the largest gastropod species in the present material. The specimens at hand agree well with zu Münster's (in Goldfuss 1844) type specimen from Berg near Altdorf (Franconia). The material illustrated by Sieberer (1907) is too poorly preserved and documented to establish species identity.

Occurrence. - Late Toarcian and early Aalenian.

\section{Pleurotomaria escheri Goldfuss, 1844}

Figure $5 \mathrm{~A}-\mathrm{C}$

*1844 Pleurotomaria escheri sp. nov.; Goldfuss, p. 70, pl. 184, fig. 9.

1844 Pleurotomaria studeri sp. nov. - Zu Münster in Goldfuss, p. 70, pl. 184, fig. 11.

1907 Pleurotomaria escheri. - Sieberer, p. 20, pl. 1, fig. 11a, b.

1997 Pleurotomaria escheri. - Hägele, p. 17, pl. 2, fig. 1.

2009 Pleurotomaria escheri. - Schulbert \& Nützel, p. 477, fig. 2 .

Material. - 3 specimens from Mistelgau; BSPG 2011 XLII 221, 222, 223.

Description. - Shell broadly gradate; specimen illustrated in Fig. 5A, B comprises four whorls, is $3.3 \mathrm{~cm}$ broad and $2.8 \mathrm{~cm}$ high; apex including protoconch missing; whorl profile step-like with broad, somewhat oblique subsutural ramp; whorls below ramp steep, nearly parallel to shell axis with broad selenizone somewhat below mid-whorl; selenizone bordered by two spiral threads, adapical thread more pronounced; ramp with prominent wave-like, prosocline, slightly prosocyrt axial ribs (about 20 per whorl); ribs form nodular bulge in the narrow zone between selenizone and 
abapical suture; whorls with distinct thread-like growthlines; faint spiral cords and growth-lines produce a reticular pattern; eight spiral cords on ramp of last whorl; base convex with rounded angular edge at junction with whorl face; base distinctly umbilicated, ornamented with numerous spiral cords; axial ribs and growth-lines on base are sigmoidal with a prosocyrt portion on transition of edge to whorl face.

Remarks. - Pleurotomaria escheri is somewhat more high-spired than P. quenstedti and it has a coarser ornament.

Occurrence. - Surface collection, early Aalenian.

Superfamily Discohelicoidea Schröder, 1995

Family Discohelicidae Schröder, 1995

Remarks. - Szabó (2009) discussed the systematic placement of discohelicids in detail and placed this group in Euomphalina and Euomphalina in Vetigastropoda (see also Bandel \& Frýda 1998, Nützel 2002a). The present representative Discohelix guembeli adds no new information about the debated relationships of Palaeozoic euomphalids and Mesozoic discohelicids.

\section{Genus Discohelix Dunker, 1847}

Type species. - Discohelix calculiformis Dunker, 1847; early Pliensbachian; N Germany.

\section{Discohelix guembeli von Ammon, 1892}

Figure 6A-D

*1892 Discohelix guembeli sp. nov.; von Ammon, p. 215, fig. 39.

Material. - One specimen from surface collection, BSPG 2011 XLII 224.

Description. - Shell planispiral with deeply concave upper and lower sides; shell diameter $15 \mathrm{~mm}$, shell height $4.8 \mathrm{~mm}$; lower side (assuming dextrality) deeper than upper side; whorls angular, trapezoidal in transverse section; last preserved whorl with 21 prominent and oblique ridge-like ribs on lower and upper edges of periphery; ribs fade towards centre of whorls; ribs also weaker in the middle of whorl sides so that whorl sides appear concave; ribs straight, orthocline on whorl sides and oblique backward (opisthocline) on upper and lower sides with a prosocyrt portion near sutures; ribs much weaker on early teleoconch whorls; whorls covered with growth lines parallel to ribs and numerous spiral grooves and threads with increasing density towards periphery; protoconch not preserved.

Remarks. - Von Ammon (1892) described Discohelix guembeli from the lowermost Opalinuston (either late Toarcian or early Aalenian) S of Creez (Oberfranken, SE Bayreuth, upper part of the streamlet Mistelbach, in short distance to the Mistelgau clay pit). We have at hand a single specimen from Mistelgau, which agrees very well with the illustration given by von Ammon (1892). It is obviously a rare species in Franconia. Gründel (2005b) transferred the species to the genus Asterohelix. Discohelix guembeli resembles the genus Asterohelix Szabó, 1984 by having strong radial ribs. However, Asterohelix has gradate whorls within the umbilicus and this character is absent in the present species (Szabó written communication 2013). Discohelix guembeli closely resembles Asterohelix exiqua (Brösamlen 1909) from the late Hettangian to early Sinemurian of BadenWürttemberg (see Gründel 2003). According to Gründel (2003), D. guembeli is larger and has a deeper upper side. Moreover, the differences in stratigraphical occurrence render a possible synonymy of both species unlikely. In addition, the axial ribs are distinctly oblique in $D$. guembeli but they are straight radial in A. exiqua. Moreover, A. exiqua has continuous radial ribs from suture to suture on the upper side of the early whorls whereas axial ribs cease towards the inner suture in D. guembeli. Asterohelix exiqua also has a spiral crest on the upper side of the early teleoconch whorls (Gründel 2003) whereas D. guembeli lacks this feature. Thus, it is unlikely that both species are synonyms. However, it is likely that $D$. guembeli is a direct descendant of the older A. exiqua. Discohelix aff. guembeli as reported by Guzhov (2009) from the early Callovian of Crimea resembles A. guembeli but its ribs are much weaker.

Kuhn (1935) reported Discohelix albinatensis Dumortier, 1874 from the late Toarcian/early Aalenian of Franconia. However, his illustration, as well as that of Dumortier's original material from the opalinum Zone of France (Dumortier 1874, pl. 59, figs 3-5) show specimens with much weaker ribs and with a slower increase of the whorls than in A. guembeli.

Occurrence. - Toarcian/Aalenian transition.

Superfamily Trochoidea Rafinesque, 1815

Family Eucyclidae Koken, 1896

\section{Genus Eucyclus Eudes-Deslongchamps, 1861}

Type species by original designation. - Eucyclus obeliscus Eudes-Deslongchamps 1861, middle Liassic (probably Charmouthien, margaritatus Zone), gastropod bed at Fontaine-Étoupefour. Wenz (1938) designated E. ornatus 


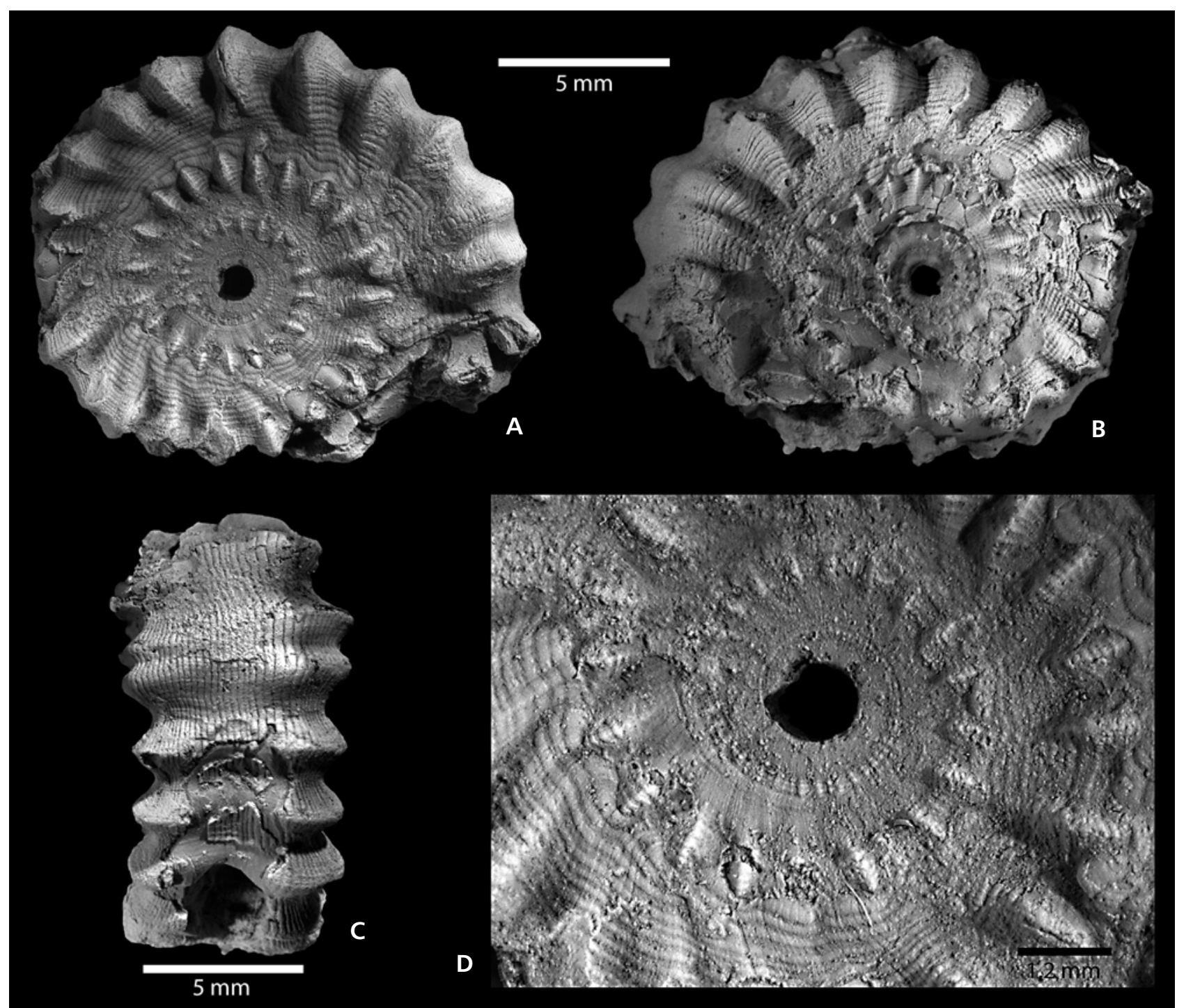

Figure 6. Discohelix guembeli von Ammon, 1892, Mistelgau, surface collection, BSPG 2011 XLII 224.

(Sowerby) as type species. However, Eudes-Deslongchamps (1861) clearly designated E. obeliscus as type.

\section{Eucyclus capitaneus (zu Münster in Goldfuss, 1844)} Figure 7A-C

*1844 Turbo capitaneus sp. nov.; zu Münster in Goldfuss, p. 97 , pl. 194, fig. 1 .

1858 Turbo capitaneus. - Quenstedt, p. 314, pl. 43, fig. 21.

1884 Turbo capitaneus. - Quenstedt, p. 430, pl. 202, figs 5, 6.

1892 Amberleya capitanea. - Hudleston, p. 277, pl. 21, fig. 12.

1909 Eucyclus capitaneus. - Brösamlen, p. 257, pl. 20, figs 8,9 .

1935 Eucyclus capitaneus. - Kuhn, p. 136, pl. 10, fig. 3.

1966 Amberleya (Eucyclus) capitanea. - Klöcker, p. 238, fig. 7.
1997 Amberleya (Eucyclus) capitanea. - Hägele, p. 64, lower left fig.

Material. - One specimen from the Urwelt-Museum Oberfranken, Bayreuth, BT 005254.00, Neusig.

Description. - Shell turbiniform; illustrated specimen (Fig. 7A-C) is $29.6 \mathrm{~mm}$ high and $24.3 \mathrm{~mm}$ wide; shell comprises about 3.5 whorls, apex missing; whorls angulated at 2 prominent node-bearing keels; adapical keel at about $3 / 4$ of whorl face; slightly more pronounced abapical keel at about $1 / 3$ of whorl face; suture indistinct, flat, just overlapping third nodular keel, that becomes exposed on last whorl as periphery; it is nearly as prominent as the former keels; whorls with numerous axial threads interconnecting spiral keels; axial threads run opisthocyrt between spiral keels; axial threads form a somewhat irregular zigzag-like pattern; base 
in principal with same ornament as whorl face: with two somewhat less developed knobby spiral keels and axial thread-like ornamentation; inner lip reflexed, rounded.

Remarks. - Eucyclus capitaneus is a rare species. We have only a single specimen at hand. It was one of the species which were originally included in Eucyclus by EudesDeslongchamps (1861). However, the characteristic ornament of axial threads which are opisthocyrt between the spiral keels is unusual for the genus Eucyclus and seems to be absent in the Pliensbachian type species. Thus, E. capitaneus could also represent another genus.

Occurrence. - Early Aalenian.

\section{Genus Eucycloidea Hudleston, 1888}

Type species. - Turbo bianor d'Orbigny 1850, Bajocian, France.

Eucycloidea tenuistria (zu Münster in Goldfuss, 1844) comb. nov.

Figure 8A-M

*1844 Rostellaria tenuistria sp. nov.; zu Münster in Goldfuss, p. 16, pl. 169, fig. 9.

1844 Rostellaria nodosa sp. nov. - Zu Münster in Goldfuss, p. 16, pl. 169, fig. 10.

1844 Trochus sedgwicki sp. nov. - Zu Münster in Goldfuss, p. 53, pl. 179, fig. 4 .

1844 Turbo subangulatus sp. nov. - Zu Münster in Goldfuss, p. 98, pl. 194, fig. 5 .

1901 Amberleya tenuistria. - Schlosser, p. 543.

1909 Eucyclus subangulatus. - Brösamlen, p. 258, pl. 20, fig. 10 (here more synonymy).

1935 Eucyclus subangulatus. - Kuhn, p. 137, pl. 10, fig. 4.

1966 Amberleya (Eucyclus) tenuistria. - Klöcker, p. 239, fig. 8 .

1997 Amberleya (Eucyclus) tenuistria. - Hägele, p. 64, with fig.

2001 Amberleya (Eucyclus) subimbricata. - Fürsich et al., p. 176 , fig. $4 \mathrm{D}$.

Material. - 12 specimens; 3 specimens from Mistelgau: BSPG 2011 XLII 6, 57, surface collection, BSPG 2011 XLII 199, $0 \mathrm{~cm}$; 9 specimens from the Urwelt-Museum Oberfranken, Bayreuth, BT 6366, Unnersdorf (Collection Frosch).

Description. - Shell slender pagodiform; specimen illustrated on Fig. 8K, L is $18.7 \mathrm{~mm}$ high, $11.2 \mathrm{~mm}$ wide and comprises about 8.5 whorls; whorls with keel-like angulation that appears just above suture on early teleoconch

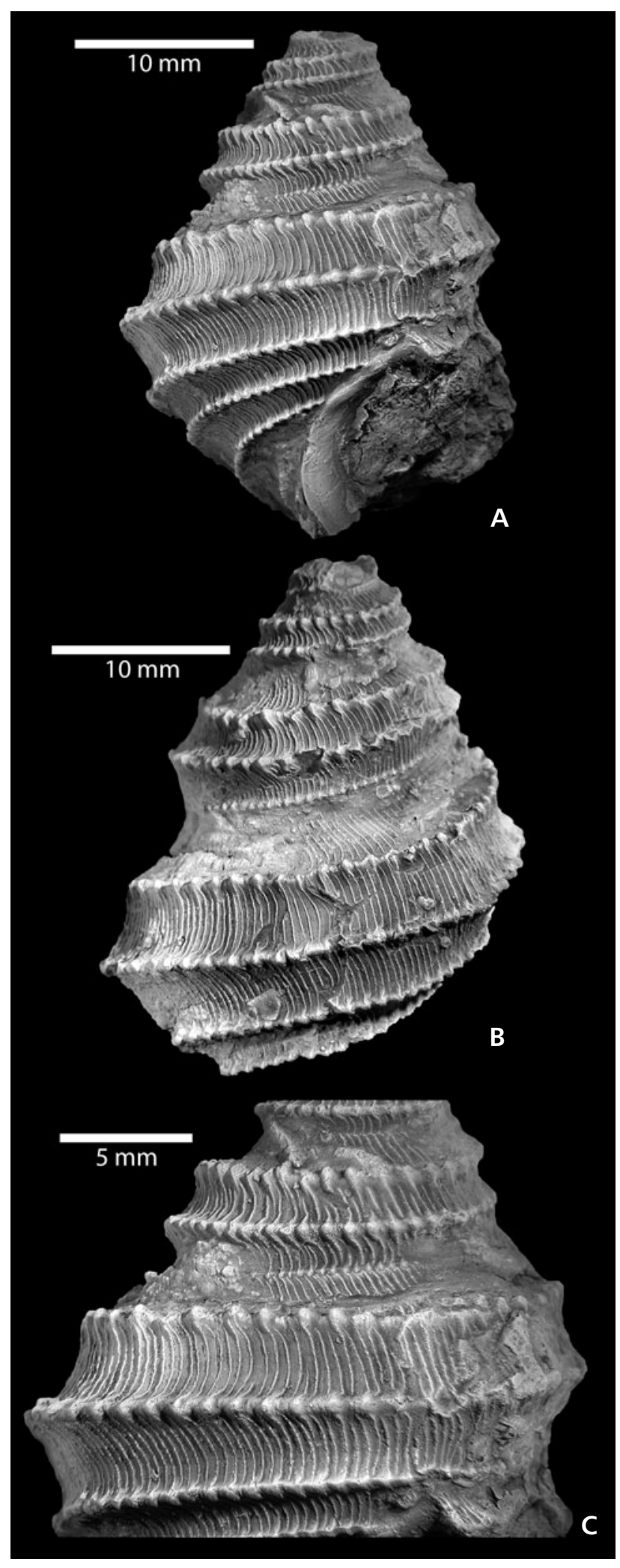

Figure 7. Eucyclus capitaneus (zu Münster in Goldfuss, 1844), Urwelt-Museum Oberfranken, Bayreuth, BT 005254.00, Neusig. 
whorls, then shifts to midwhorl and strengthens; along ridge of angulation, a single carina develops; ramp concave and steeply sloping; outer whorl face concave and almost parallel to shell axis; first teleoconch whorl with narrow, densely spaced axial ribs and without keel (Fig. 8F); following early teleoconch whorls with prominent prosocline continuous axial ribs which form nodules at spiral cord below suture and on suprasutural carination; axial ribs are reduced on mature teleoconch whorls; mature teleoconch whorls covered with fine spiral threads and strengthened opisthocyrt fine axial threads forming a reticulate pattern on whorl face; three spiral threads on keel of mature teleoconch whorls are more pronounced; carina and subsutural spiral cord ornamented with axially elongated nodules; suture shallow, indistinct; base convex with 5-7 distinct spiral cords without knobs; abapical spiral cord developed as boundary between whorl face and base; aperture slightly oval with tapering adapical area.

Remarks. - Schlosser (1901, p. 543) synonymised four species from the Aalenian (or late Toarcian) of N Bavaria which were erected by zu Münster in Goldfuss (1844): Rostellaria tenuistria, $R$. nodosa, Trochus sedgwicki and Turbo subangulatus. This is seemingly correct although Rostellaria tenuistria seems to differ from the other taxa by having a finer ornamentation, which could be due to preservation or variability. The species is probably best known as Eucyclus subangulatus (Brösamlen 1909, Kuhn 1935). Brösamlen (1909) accepted the synonymy of the four taxa but kept E. subangulatus, although Rostellaria tenuistria has line and page priority. Fürsich et al. (2001) reported Eucycloidea tenuistria as Amberleya (Eucyclus) subimbricata (d'Orbigny, 1850) from the Toarcian of France. The illustrated specimen (Fürsich et al. 2001, fig. 4D) is undoubtedly conspecific with our material from Franconia.

Eucycloidea tenuistria and its synonyms were previously placed in the genus Eucyclus. However, judging from the teleoconch ornamentation (axially elongated nodes on peripheral carination and fine spiral threads), it is much closer to the type and other species of Eucycloidea (compare Gründel 1997a, pl. 4, figs 1-7) than to that of Eucyclus. In passing by, we note that Eucycloscala izabellae Kaim, 2004 from the Bathonian of Poland is very similar to Eucycloidea granulata from the Callovian of France. We therefore transfer Eucycloscala izabellae to Eucycloidea. Eucycloidea tenuistria from Franconia differs from the Eucycloidea species reported by Gründel (1997a) and Kaim (2004) in lacking an angulation and keel at the transition to the base.
Here we can show for the first time the continuous and strong axial ribs of the early teleoconch whorls for E. tenuistria. The status of this character is not clear for the type species of Eucycloidea, but was reported by Kaim (2004) for Eucycloscala izabellae. Axial ribs on the early teleoconch are typical for the family Eucycloscalidae Gründel, 2007b. It is unknown, whether Eucyclidae show this character because the early ontogeny of the type species of Eucyclus is unknown.

Occurrence. - Early Aalenian.

\section{Mistelgauia Schulbert \& Nützel gen. nov.}

Type species. - Mistelgauia monarii sp. nov.

Etymology. - After the village Mistelgau.

Diagnosis. - Shell with conical spire and strongly convex base; first teleoconch whorls with numerous prosocline sharp axial ribs; later whorls with a row of subsutural axially elongated nodes and short ribs at abapical suture; whorl between sutural nodes and ribs straight and smooth; base joining whorl face at angulation at or slightly above suture; base ornamented with at least 7 distinct spiral cords and numerous axial threads which continue onto whorl face and form the suprasutural riblet zone there.

Remarks. - Mistelgauia has axial ribs on the early teleoconch, which is typical for Eucycloscalidae. It differs from Eucycloscala in having a wide zone without ornament on the whorl face and in having no pronounced spiral cords on the whorl face. Calliotropis has a stronger ornament of axial and spiral cords with strong nodes on the intersections and it has fewer but stronger spiral cords on the base. Mistelgauia differs from Amphitrochus and Costatrochus in having axial ribs on the early teleoconch whorls and in having a distinctly convex base with a reticulate ornament of narrow but distinct axial and spiral cords.

Callotrochus Kutassy in Wenz, 1938 from the late Triassic of Hungary has a similar shape but lacks ornamentation. This genus was placed in Callotrochinae Szabó, 2011 by Szabó (2011) who also included the late Triassic genus Tylotrochus Koken, 1896 in this subfamily. Tylotrochus differs from Mistelgauia by having a reticulate ornament in early teleoconch whorls, which changes subsequently to an ornament of broad spiral bands (A.N., personal observation 2012). Eucyclomphalus von Ammon, 1892 is much

Figure 8. Eucycloidea tenuistria (zu Münster in Goldfuss, 1844). • A - Mistelgau, BSPG 2011 XLII 6, surface collection. • B, F- BSPG 2011 XLII 199, $0 \mathrm{~cm}$. - C, D, G, I - Urwelt-Museum Oberfranken, Bayreuth, BT 6366.01, Unnersdorf. • E, H - BSPG 2011 XLII 57, surface collection. - J-M - Urwelt-Museum Oberfranken, Bayreuth, BT 6366.01, Unnersdorf. 


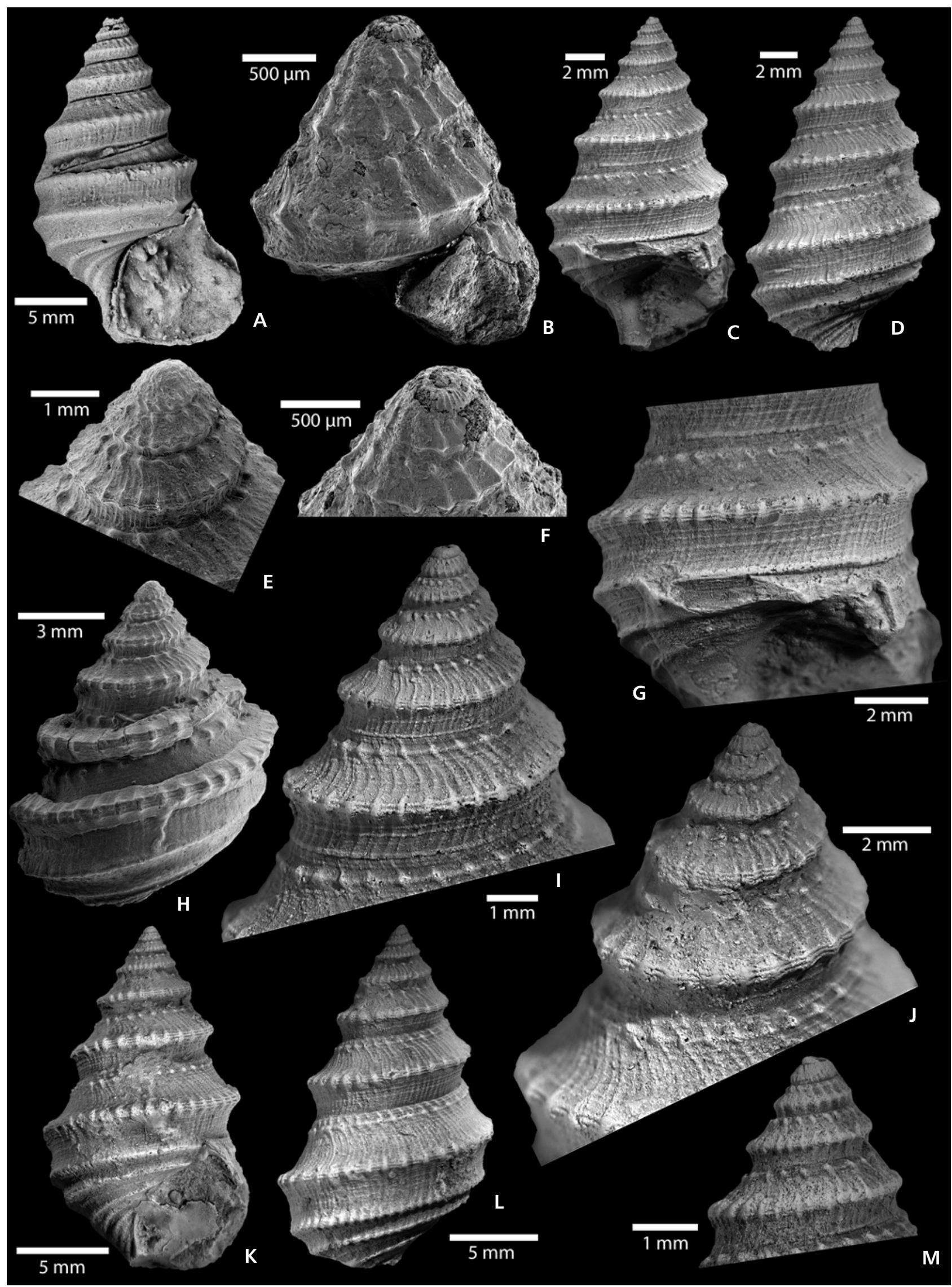


more slender, widely phaneromphalous and lacks subsutural ornament.

Besides the type species, we also include Tylotrochus raresculptatus Gründel, 1999b from the Pliensbachian of N Germany (Grimmen) in the new genus Mistelgauia. We tentatively place the new genus Mistelgauia in Eucyclidae although it seems to differ from typical representatives of this genus in some respect.

Other species. - Tylotrochus raresculptatus Gründel, 1999b from the Pliensbachian of N Germany (Grimmen).

Occurrence. - Pliensbachian to late Toarcian/early Aalenian.

\section{Mistelgauia monarii sp. nov.}

Figure 9A-I

?1892 Amberleya biserta (Phillips). - Hudleston, p. 288, pl. 22, figs 13,14 , pl. 23, figs $1,2$.

1935 Eucyclus ex aff. bisertus. - Kuhn, p. 138, pl. 9, fig. 3a, b.

?1935 cf. Eucyclus ex aff. bisertus. - Kuhn, p. 139, pl. 8, fig. 19.

2009 Eucyclus cf. bisertus. - Schulbert \& Nützel, p. 479, fig. 4.

2011 Tylotrochus sp. -Gründel et al., p. 103, pl. 3, figs 1, 2.

Types. - Holotype 2011 XLII1, Fig. 9A-C; 6 paratypes: BSPG 2011 XLII 133, $220 \mathrm{~cm}$ below Lytoceras bed; BSPG 2011 XLII 134, $220 \mathrm{~cm}$ below Lytoceras bed; BSPG 2011 XLII 138, 40-60 cm below Lytoceras bed; BSPG 2011 XLII 139, 40-60 cm below Lytoceras bed; BSPG 2011 XLII 190, $180 \mathrm{~cm}$ below Lytoceras bed; BSPG 2011 XLII 211, $600 \mathrm{~cm}$ above Lytoceras bed.

Type horizon and locality. - Late Toarcian/early Aalenian, Opalinuston Formation, Mistelgau clay pit, Oberfranken, Germany.

Material. - Types and 27 juvenile specimens; BSPG 2011 XLII 73, $140 \mathrm{~cm}$ below Lytoceras bed, BSPG 2011 XLII 92, 40-60 cm below Lytoceras bed.

Etymology. - After Stefano Monari, Padova, Italy for his work on Mesozoic gastropods.

Diagnosis. - Mistelgauia species with relatively strong riblets near sutures and with distinct suprasutural edge on spire whorls.

Description. - The holotype comprises about five whorls, is $3.1 \mathrm{~mm}$ high and $2.7 \mathrm{~mm}$ wide; shell trochiform with conical spire and round, convex base; apical angle about 70 degrees; suture distinct, canaliculate; first whorl without visible ornament but corroded; then about 1.3 whorls with straight, sharp, continuous, prosocline ribs; ribs reduced subsequently except of narrow subsutural and suprasutural zones; distinct spiral thread after second whorl in suprasutural position; mature ornament after 2.5 whorls, consisting of zones with riblets near adapical and abapical suture; subsutural zone with relatively strong, widely spaced, axially elongated riblets, nodular near suture, prosocline, fading towards middle of whorl face, numbering about 20 per whorl; suprasutural zone with numerous, densely spaced, fine but distinct axial threads just above lower suture, continuing onto base, becoming weaker below uppermost spiral thread on base; distinct spiral thread little above lower suture on angulation forming periphery of shell; whorl face smooth between upper and lower riblet-zones; whorls angulated at suprasutural spiral thread: conical and straight above thread, straight and parallel to shell axis below suprasutural spiral thread; base convex below periphery; base with at least eight distinct spiral threads and numerous straight axial threads.

Remarks. - Mistelgauia monarii sp. nov. was first reported by Kuhn (1935) and designated as Eucyclus ex aff. bisertus (Phillips, 1829). However, Trochus bisertus (Phillips, 1829 , p. 157 , pl. 11, fig. 27) from the Inferior Oolite has much stronger nodes and obviously an axial ornament which covers the entire whorls. This species could represent the genus Calliotropis (see Kaim 2004). Kuhn (1935) had three specimens from the torulosum Zone (late Toarcian) at hand, two from from Forth near Nürnberg and one from Berg. The specimen of Gründel et al. (2011, pl. 3, figs 1, 2) from the Aalenian of Geissingen (BadenWürttemberg, Germany) clearly represents Mistelgauia monarii sp. nov. To our knowledge, these are the only specimens of this species that have been reported. Therefore, it can be regarded as a rare species. The specimen that was illustrated by Kuhn (1935, pl. 8, fig. 19) is probably not conspecific but closely related. Mistelgauia raresculptata (Gründel, 1999b) from the late Pliensbachian of N Germany (Grimmen) is similar but has weaker riblets near sutures and lacks a distinct suprasutural/peripheral angulation on spire whorls.

Occurrence. - Toarcian/Aalenian transition.

Family Nododelphinulidae Cox in Knight et al., 1960

\section{Genus Costatrochus Gründel, 2009}

Type species. - Turbo subduplicatus d'Orbigny, 1850, Toarcian to Aalenian, France. 


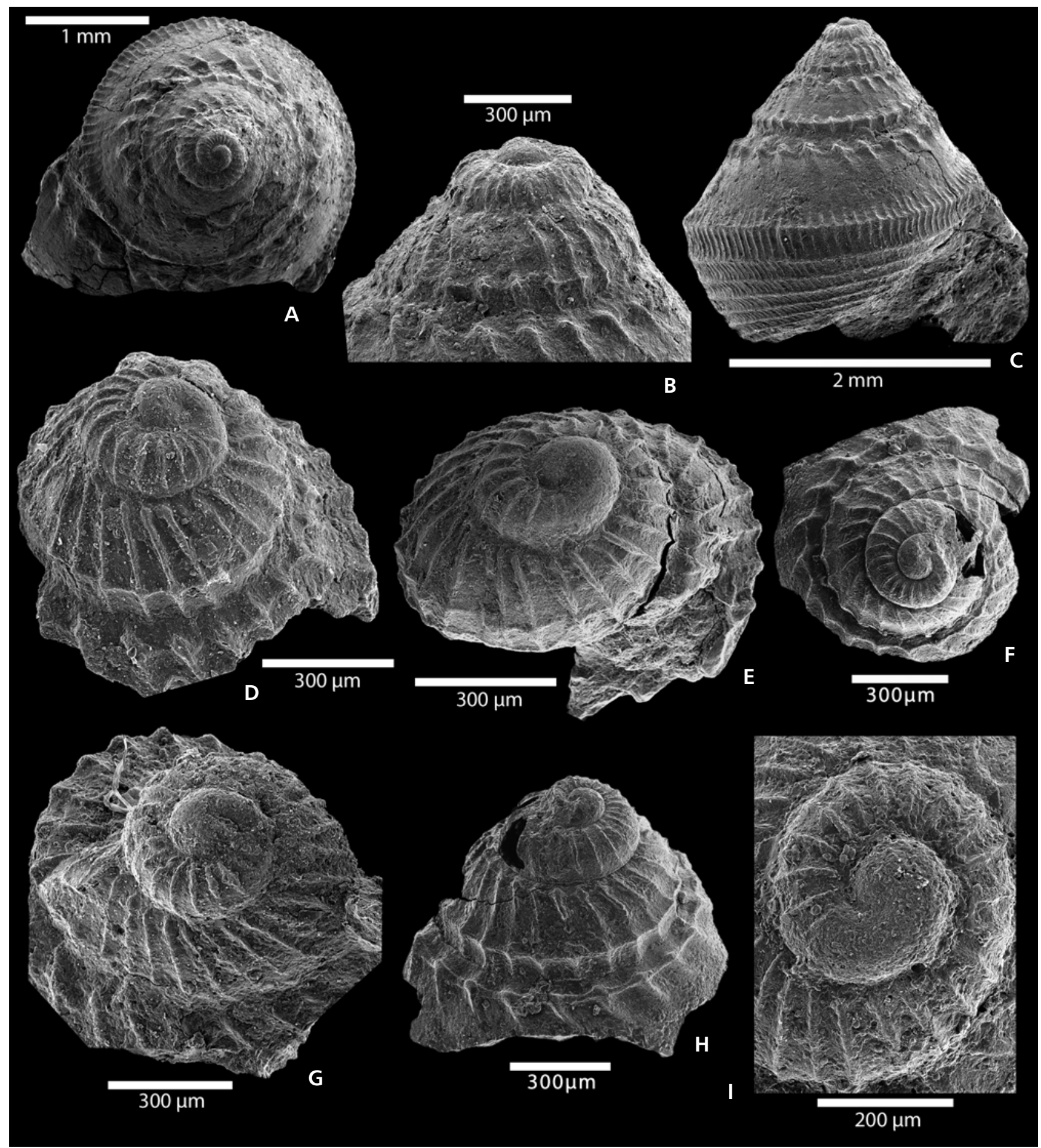

Figure 9. Mistelgauia monarii sp. nov. • A-C - holotype, BSPG 2011 XLII 1, surface collection. • I - BSPG 2011 XLII $73,140 \mathrm{~cm}$ below Lytoceras bed. - D - paratype, BSPG 2011 XLII 138, 40-60 cm below Lytoceras bed. • E - paratype, BSPG 2011 XLII 133, $220 \mathrm{~cm}$ below Lytoceras bed. - G - paratype BSPG 2011 XLII 139, 40-60 cm below Lytoceras bed. $\bullet$ F, H - paratype, BSPG 2011 XLII 211, $600 \mathrm{~cm}$ above Lytoceras bed.

\section{Costatrochus subduplicatus (d'Orbigny, 1850)} Figure 10A-D

1844 Turbo duplicatus Sowerby. - Goldfuss, p. 95, pl. 179, fig. $2 a-c$.
1966 Amphitrochus subduplicatus. - Klöcker, p. 242, fig. 9.

2009 Costatrochus subduplicatus var. palinurus (d'Orbigny, 1850). - Gründel, p. 208, figs 2D, E-M, 4 A-E, H-I. 


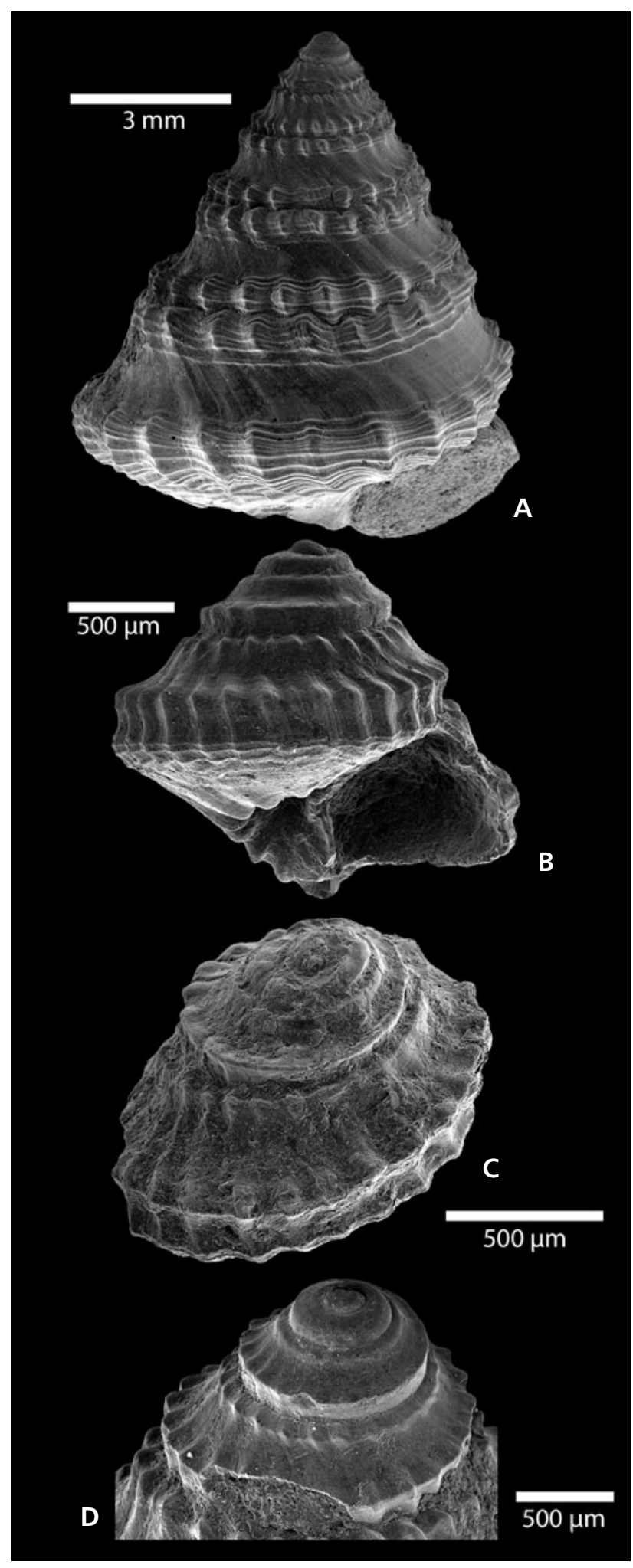

Figure 10. A, D - Costatrochus subduplicatus (d'Orbigny, 1850), BSPG XLII 36, surface collection. - B - Costatrochus subduplicatus, BSPG XLII 116, $310 \mathrm{~cm}$ below Lytoceras bed. - C - Costatrochus subduplicatus, BSPG XLII $110,610 \mathrm{~cm}$.
2009 Amphitrochus subduplicatus (d'Orbigny, 1850). Schulbert \& Nützel, p. 481, fig. 5.

For more synonymy see Gründel (2009).

Material. - BSPG 2011 XLII 35-36, surface collection; BSPG XLII 110, 610 cm, Fig. 10C; BSPG 2011 XLII 116-117, $310 \mathrm{~cm}$; BSPG 2011 XLII 124, $310 \mathrm{~cm}$.

Description. - Shell conoidal; largest illustrated specimen comprises 8 whorls, $8.3 \mathrm{~mm}$ broad, $9.3 \mathrm{~mm}$ high; first 1.5 to 2 whorls (including protoconch) smooth, convex; further early teleoconch whorls with angulation slightly below mid-whorl and broad concave ramp between angulation and adapical suture; early whorls concave below angulation and nearly parallel to shell axis; on third whorl, angulation shifts gradually toward abapical suture and axially elongated nodes (rib-like) appear on angulation and run to abapical suture; ribs also present in a subsutural zone but are absent or weak between adapical and abapical nodes; mature teleoconch whorls concave with about 24-26 strong elongated and prosocline nodes in sub- and suprasutural position; number of nodes per whorl remains constant over all whorls; both nodular bulges covered with spiral threads; these threads increase in number from 4 to $9 \mathrm{du}-$ ring ontogeny and become stronger; whorl face between sutural bulges concave, smooth with exception of prosocline and slightly sigmoidal growth-lines; suture slightly impressed; suture wavy because of alternating sub- and suprasutural nodes; base flatly convex, phaneromphalous with numerous spiral threads and wavy radial ribs especially near umbilicus.

Remarks. - Costatrochus subduplicatus is a characteristic vetigastropod, which is well known from Germany, France and England. An intensive discussion of this taxon was given by Brösamlen (1909) and Gründel (2009). Brösamlen (1909) described also larger specimens and reported morphological details about the aperture and base. The early ontogenetic development was first described by Schulbert \& Nützel (2009). Fürsich et al. (2001) reported a high abundance of this species from Causses (Southern France). These authors reported that A. subduplicatus forms nearly $40 \%$ benthos samples and that it forms the most abundant species of the "A. subduplicatus-Palaeonucula hammeri association". Fürsich et al. (2001) interpreted A. subduplicatus as a detritivore gastropod, feeding mainly on plant material, which is in accordance with the common interpretation of the autecology of trochomorph vetigastropods. However, the trophic role of Recent vetigastropods is more complex than previously known; e.g., spongivory is common, which is reflected by a complex morphology of the radula (e.g. Hickman 1984, Geiger et al. 2008).

Occurrence. - Late Toarcian and early Aalenian. 


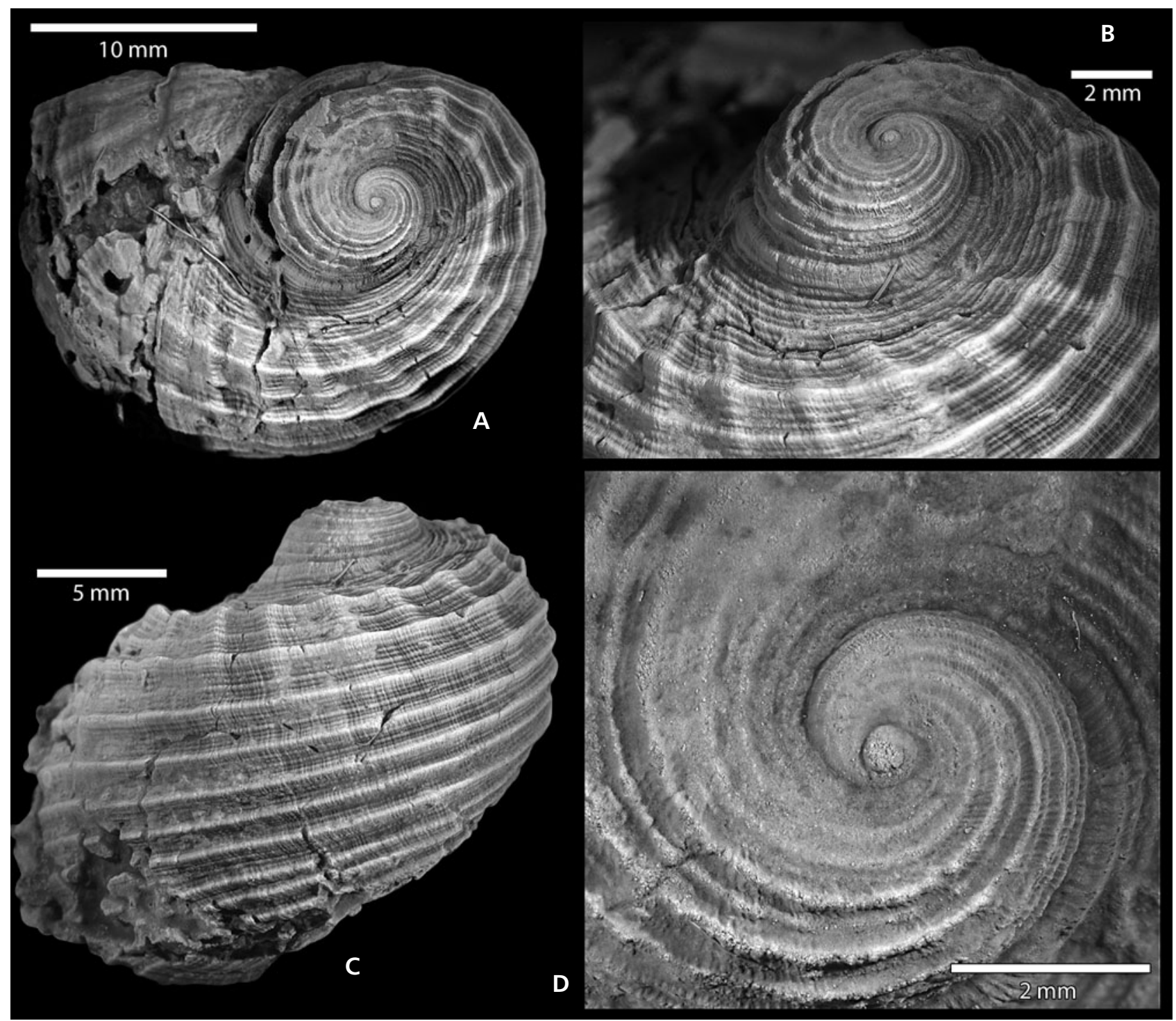

Figure 11. Neritopsis opalina Brösamlen, 1909, Mistelgau, collection Eggmaier, Urwelt-Museum Oberfranken, Bayreuth.

Subclass Neritimorpha Koken, 1896

Family Neritopsidae Gray, 1847

\section{Genus Neritopsis Grateloup, 1832}

Type species. - Neritopsis radula (Linnaeus, 1758), Recent.

\section{Neritopsis opalina Brösamlen, 1909}

Figure 11A-D

*1909 Neritopsis opalina sp. nov.; Brösamlen, p. 239, pl. 19, fig. 21.

Material. - One specimen from Mistelgau, UrweltMuseum Oberfranken, Bayreuth, collection Eggmaier.
Description. - Neritiform, low-spired shell; illustrated specimen is $19.3 \mathrm{~mm}$ high and $22.5 \mathrm{~mm}$ wide; teleoconch comprises about 2.8 whorls; whorl face convex with distinct upper angulation and ramp; ramp broad and shallow, somewhat concave in the last teleoconch whorl; suture distinct; first two teleoconch whorls form a plateau; whorls exhibit numerous densely spaced spiral cords and threads of variable thickness; prominent spiral cord angulating whorl face at edge delimiting ramp; whorl face below angulation covered with 4 more prominent spiral cords; later teleoconch whorls with about 15 prosocline axial ribs forming a wave-like structure at intersection with spiral cords; axial ribs most prominent at angulating edge and fading adapically; strengthened prosocline growth lines on whorl face; base convex exhibiting spiral cords and threads; protoconch elevated, knob-like, probably 
consisting of several whorls, but not very well preserved; aperture not exposed.

Remarks. - Neritopsis opalina is very rare. It is only known from the type specimen from the Aalenian of Heiningen in Baden-Württemberg described by Brösamlen (1909) and the present specimen from Mistelgau. Brösamlen had only a shell fragment, which shows the same type of characteristic spiral ornament that is present in our specimen. The Recent Neritopsis radula lacks a ramp and has a more nodular ornament. Generally, neritimorph species are rare in the soft bottom communities of the Early and Middle Jurassic of Germany.

Occurrence. - Lower Aalenian.

Subclass Caenogastropoda Cox, 1960

Family Coelodiscidae Gründel \& Nützel fam. nov.

Diagnosis. - Small (less than $1 \mathrm{~mm}$ or a few millimetres) nearly planispiral, thin-shelled gastropods with feebly concave to slightly elevated spire. The first whorl (embryonic shell) is smooth. The rest of the shell is ornamented with spiral threads or axial ribs and furrows.

Included genera. - Coelodiscus Brösamlen, 1909 and Tatediscus Gründel, 2001a.

Remarks. - The new family Coelodiscidae comprises small, nearly planispiral shells which represent probably holoplanktonic gastropods. This seems to be the oldest example for this mode of life in Gastropoda. We place the new family in the holoplanktonic suborder Heteropoda Lamarck, 1812. Formerly, Coelodiscus and Tatediscus were either placed in the Palaeozoic family Euomphalidae or in modern families of the Heteropoda, e.g. Carinariidae or Atlantidae. Bandel \& Knitter (1983) and Bandel \& Hemleben (1987) compared Coelodiscus directly with larval shells of modern Atlantidae. There is a clear resemblance supporting this. However, there is no indication that Coelodiscus represents a larval shell. It reaches a maximum size of about $3 \mathrm{~mm}$ and was never found attached to any tertiary type of shell (in addition to the embryonic shell and the spirally ornamented secondary shell). As Bandel \& Hemleben (1987) stated: "Coelodiscus has no Recent counterpart ...". A more detailed analysis of the new family is underway.

\section{Genus Coelodiscus Brösamlen, 1909}

Type species. - Euomphalus minutus Schübler in Zieten, 1832, Early Jurassic, Germany.
Remarks. - Jefferies \& Minton (1965), Bandel \& Knitter (1983), Bandel \& Hemleben (1987) and Bandel (1993, p. 26) interpreted Coelodiscus as planktonic gastropod. However, Kauffman (1981) and Etter (1990, 1996) suggested that Coelodiscus could also represent opportunistic benthos. We find the arguments of Jefferies \& Minton (1965) and Bandel \& Hemleben (1987) rather convincing and interpret this gastropod as planktonic. The arguments are the very thin shell, the resemblance to modern heteropods, and the high abundance of Coelodicus in oxygen depleted sediments (Posidonia Shale). Röhl (1998) confirmed that Coelodiscus is present even if benthic conditions were unfavourable for life and therefore Coelodiscus had a mode of life independent from the bottom.

The genus Coelodiscus is known from the Pliensbachian to the Aalenian and it is most abundant in the Toarcian Posidonia-Shale (Brösamlen 1909). These snails are small, multi-whorled and thin-shelled. In our samples (washed residues of shales), they occur as pyritic steinkerns only. Bandel \& Knitter (1983), Bandel \& Hemleben (1987) and Teichert (2009) investigated well-preserved casts and found that the teleoconch has a fine spiral ornament. Since Coelodiscus was most probably planktonic, presence or absence of this gastropod has no impact on the reconstruction of the benthic community. However, if Coelodiscus is abundant in samples and represents the only gastropod or is strongly dominant, this probably means that benthic live was primarily poor and not biased by diagenetic or other preservation effects.

\section{Coelodiscus minutus (Schübler in Zieten, 1833)} Figure $12 \mathrm{~A}-\mathrm{F}$

*1833 Euomphalus minutus sp. nov.; Schübler in Zieten, p. 45 , pl. 33, fig. 6 .

1909 Coelodiscus minutus. - Brösamlen, p. 203, pl. 17, figs 9-11.

1935 Coelodiscus minutus. - Kuhn, p. 132, pl. 9, fig. 18a-c.

1965 Coelodiscus minutus. - Jefferies \& Minton, p. 181.

1966 Coelodiscus minutus. - Klöcker, p. 244, fig. 10.

1981 Coelodiscus minutus. - Kauffman, p. 350.

1983 Coelodiscus minutus. - Bandel \& Knitter, p. 112, figs 5,6 .

1984 Coelodiscus minutus. - Riegraf et al., p. 40, figs 1, 2.

1987 Coelodiscus minutus. - Bandel \& Hemleben, p. 5, figs 1-3, 6-8.

?1987 Coelodiscus fluegeli sp. nov. - Bandel \& Hemleben, figs $1,3-7$.

1990 Coelodiscus minutus. - Etter, p. 24, 26, 72, pl. 5, figs 2, 3 .

1993 Coelodiscus minutus. - Bandel, p. 26, pl. 13, fig. 2.

1995 Coelodiscus minutus - Etter, p. 261, 264, 268.

?1996 Coelodiscus sp. - Etter, p. 338, fig. 9. 


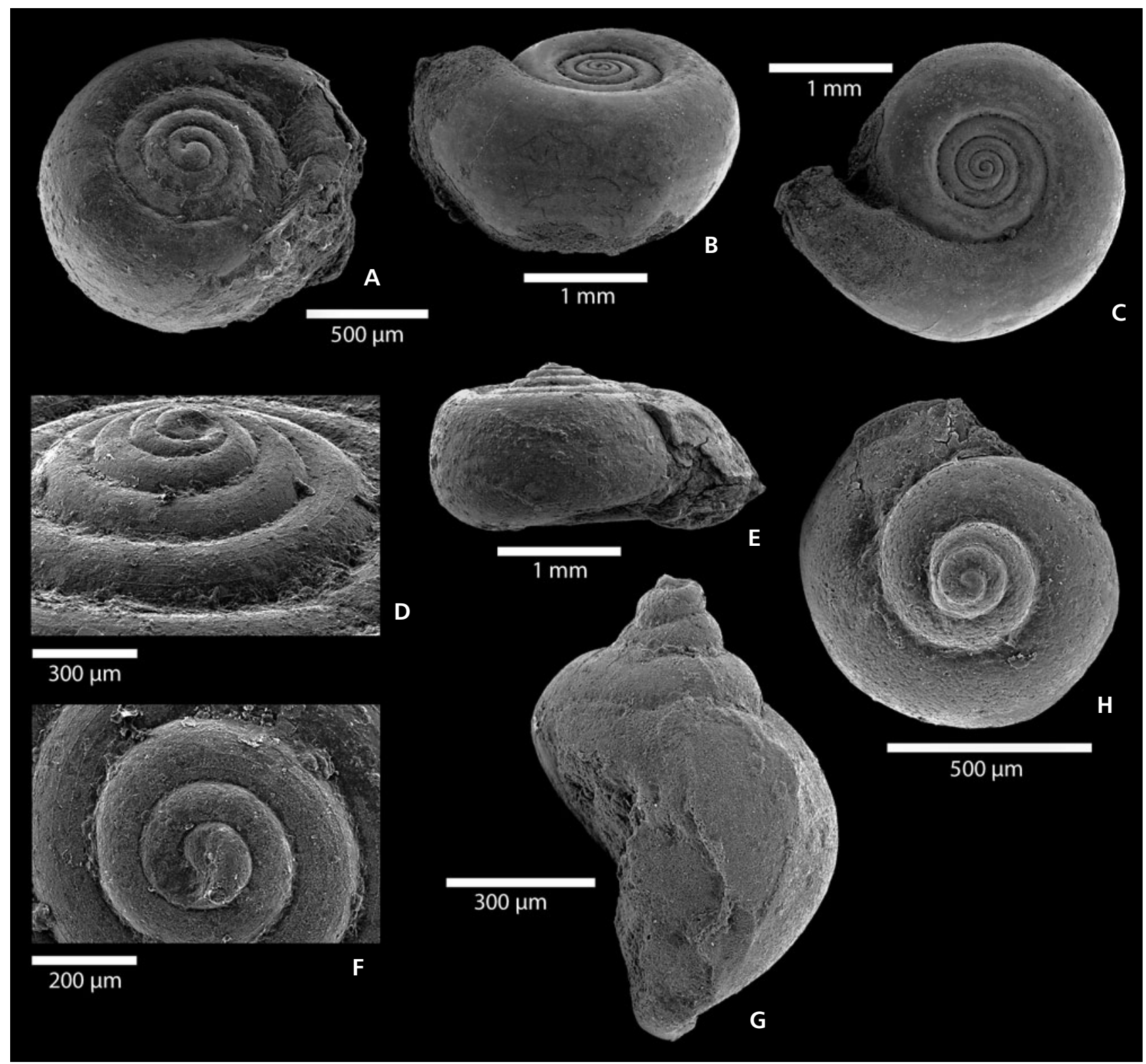

Figure 12. A - Coelodiscus minutus (Schübler in Zieten, 1833), BSPG 2011 XLII 187, $460 \mathrm{~cm}$ below Lytoceras bed. • B, C - Coelodiscus minutus, BSPG 2011 XLII 165, $740 \mathrm{~cm}$ below Lytoceras bed. - D-F - Coelodiscus minutus, BSPG 2011 XLII 147, $150 \mathrm{~cm}$ below Lytoceras bed. - G - caenogastropod larval shell, BSPG 2011 XLII 177, $290 \mathrm{~cm}$ below Lytoceras bed. $\cdot$ H - caenogastropod larval shell, BSPG 2011 XLII $127,300 \mathrm{~cm}$ below Lytoceras bed.

Material. - About 2000 specimens; BSPG 2011 XLII 147, $150 \mathrm{~cm}$, Fig. 12D-F; BSPG 2011 XLII 152, $150 \mathrm{~cm}$; BSPG 2011 XLII 165, $740 \mathrm{~cm}$; BSPG 2011 XLII 187, $460 \mathrm{~cm}$, Fig. 12A; BSPG 2011 XLII 195, $780 \mathrm{~cm}$.

Description. - Nearly planispiral shells with thin wall; spire varies from shallow concave to slightly elevated apperance; roughly five tightly coiled convex whorls; about $1.5 \mathrm{~mm}$ height and 1-3 mm broad; whorls in transverse section higher than wide; whorl surface is smooth, sometimes with faint spiral threads (Fig. 12D-F); suture impres- sed; sometimes weak wave-like ornamentation of whorls near suture; base rounded, deeply umbilicated.

Remarks. - Coelodiscus minutus appears in almost all samples throughout the studied section. Kuhn (1935) reported a high abundance in the torulosum Subzone. Tatediscus aratus (Tate 1870) from the Pliensbachian of England and Germany (Schubert et al. 2008) is differentiated by its distinct axial ornamentation. Differentiation from $C$. fluegeli is more difficult. According to the original diagnosis given by Bandel \& Hemleben (1987), C. fluegeli is mainly defined by its 
spiral ornamentation. These authors presume that the spiral ornamentation is constrained to the larval shell of $C$. fluegeli but this was not mentioned in their diagnosis (Bandel \& Hemleben 1987, fig. 8). Similarly, Brösamlen (1909) mentioned spiral ornamentation for C. minutus. On plate 17, fig. 10, Brösamlen (1909) illustrated a rather large specimen ( $3 \mathrm{~mm}$ in diameter) that is distinctively spirally ornamented. This specimen has been considered as a possible $C$. fluegeli by Bandel \& Hemleben (1987). Regarding the size of this specimen, it is not very likely, that this is a larval shell. It might be possible, that $C$. minutus and $C$. fluegeli are synonyms. C. minutus is a very thin-shelled gastropod. Since the preservation of the gastropods from Mistelgau is often not optimal, C. minutus occurs commonly as internal pyritic moulds or is recrystallized and thus, fine spiral threads are commonly destroyed. Well-preserved material from concretions indicate that $C$. minutus was always or mostly spirally striated (Bandel \& Hemleben 1987, Teichert 2009).

Occurrence. - Late Toarcian and early Aalenian of Mistelgau (also present at various locations in South Germany (especially in the early Toarcian Posidonienschiefer), Northern Switzerland and England).

Family unknown

\section{Caenogastropod larval shell}

Figure 12G, H

Material. - 3 specimens; BSPG 2011 XLII 127, $290 \mathrm{~cm}$, Fig. 12H, BSPG 2011 XLII 177, 300 cm, Fig. 12G, BSPG 2011 XLII 137, 40-60 cm.

Description. - Turbiniform shell; specimen on Fig. $12 \mathrm{G}$ is $0.6 \mathrm{~mm}$ broad and $0.9 \mathrm{~mm}$ high; it comprises 4.5 whorls with impressed suture; smooth shell with no signs of ornamentation; whorl face strongly convex; base convex, smooth; aperture not preserved; first protoconch whorl is flattened; first three whorls acutely conical; last whorl strongly inflated.

Remarks. - These shells could represent a holoplanktonic gastropod like $C$. minutus. This is indicated by its small size and the absence of a distinct boundary between protoconch and teleoconch. However, it seems more likely that they represent isolated larval shells of an unknown caenogastropod.

Occurrence. - Late Toarcian and early Aalenian.

\section{Superfamily Cerithioidea Fleming, 1822}

Cerithioidea (procerithiids and cryptaulacids) species are very abundant in the Mistelgau claypit. They are present with three species and form an important component of the fauna. Cerithioids represent the most abundant group in many of the samples. Generally, cerithioids are widely distributed, diverse and commonly abundant throughout the entire Jurassic. Gründel (1999c) described 25 species from the Liassic and Dogger of Germany and Poland. The group first appeared in the Middle Triassic and is abundant and diverse since the Late Triassic (Haas 1953, Nützel \& Senowbari-Daryan 1999, Nützel 2002b, Nützel \& Erwin 2004).

Family Cryptaulacidae Gründel, 1976

\section{Genus Cryptaulax Tate, 1869}

Type species. - Procerithium (Xystrella) protortile Cox, 1969.

Cryptaulax armatum (Goldfuss, 1843)

Figure 13A-D

*1843 Cerithium armatum sp. nov.; Goldfuss, p. 29, pl. 173, fig. 7.

1909 Cryptaulax armata. - Brösamlen, p. 291, pl. 21, figs 27-29.

1999c Cryptaulax armatum. - Gründel, p. 19, pl. 5, figs 1-4. Gründel (1999c) gave a detailed synonymy.

Material. - 660 specimens; BSPG 2011 XLII 2, surface; BSPG 2011 XLII 5, surface; BSPG 2011 XLII 7, surface; BSPG 2011 XLII 8, surface; BSPG 2011 XLII 69-70, $320 \mathrm{~cm}$ below Lytoceras bed; BSPG 2011 XLII 72, 78, $320 \mathrm{~cm}$ below Lytoceras bed; BSPG 2011 XLII 104, 108, $320 \mathrm{~cm}$ below Lytoceras bed; BSPG 2011 XLII 109, $320 \mathrm{~cm}$ below Lytoceras bed; BSPG 2011 XLII 191, $180 \mathrm{~cm}$ below Lytoceras bed.

Description. - Shell high-spired, slender, turriculate; largest specimens up to $1.5 \mathrm{~cm}$ high and $5 \mathrm{~mm}$ wide; protoconch $0.5 \mathrm{~mm}$ wide and up to $0.7 \mathrm{~mm}$ high, comprising about 4 whorls; last two protoconch whorls exhibit two prominent keel-like spiral cords; teleoconch whorl profile is straight at periphery with subsutural ramp and suprasutural inception; teleoconch ornamented with axial ribs and spiral cords with nodular to spine-like intersections; keel-like spiral cords of the larval shell continue onto teleoconch whorls; adapical spiral cord is located at about $1 / 4$ of whorl height below suture, abapical spiral cord is located at about $1 / 4$ of whorl height above suture; between these two spiral cords, a third rib is intercalated from the third teleoconch whorl onward; this rib becomes weaker in the latest whorls; last protoconch whorl exhibits a suprasutural spiral cord which seems to continue on teleoconch as a bulgy 


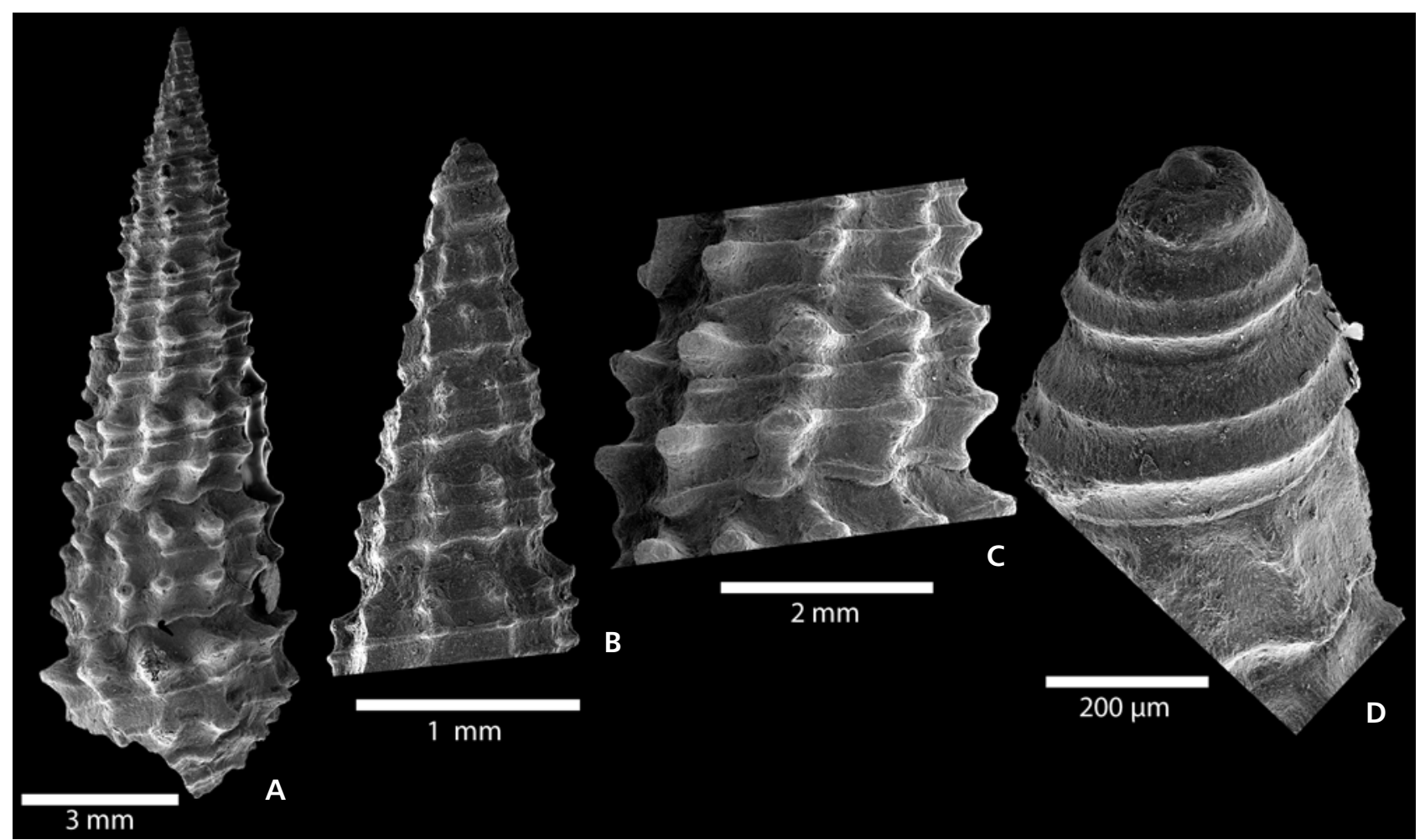

Figure 13. Cryptaulax armatum (Goldfuss, 1843). • A - BSPG 2011 XLII 5, surface collection. • B - BSPG 2011 XLII 8, surface collection. - C, D - BSPG 2011 XLII 7, surface collection.

ledge above suture; orthocline to slightly opisthocline axial ribs, ontogenetically increasing from 10 to 15 ribs per whorl; intersections of axial ribs and spiral cords with spine-like, spirally elongated prominent nodes; nodes strongest on adapical and abapical spiral, sometimes forming rounded spines; base flat with one distinct spiral cord and some additional spiral cords; aperture not sufficiently preserved in our material.

Remarks. - According to Gründel (1974), the aperture is subquadratic to rounded oval with no pronounced siphonal channel. Cryptaulax armatum is a characteristic member of the genus Cryptaulax which is well known from the Liassic and Dogger from southern Germany.

Occurrence. - Late Toarcian (rare) and early Aalenian (abundant).

Family Procerithiidae Cossmann, 1906

\section{Genus Procerithium Cossmann, 1902 in Chartron \& Cossmann (1902)}

Type species. - Procerithium quinquegranosum Cossmann in Chartron \& Cossmann, 1902, Early Jurassic, Hettangian, France.
Procerithium brandi (Walther, 1951)

Figure 14A-G

1935 Cryptaulax subarmatum Ernst, 1923. - Kuhn, p. 144, pl. 8, fig. 26a, b.

*1951 Rhabdocolpus brandi sp. nov. - Walther, p. 85, pl. 4, fig. $11 \mathrm{a}-\mathrm{d}$.

1999c Procerithium brandi. - Gründel, p. 3, pl. 1, figs 1-6. 2009 Procerithium brandi. - Schulbert \& Nützel, p. 490, fig. 11.

Material. - About 100 specimens; BSPG 2011 XLII 89, 40-60 cm below Lytoceras bed; BSPG 2011 XLII 111, $610 \mathrm{~cm}$ below Lytoceras bed, Fig. 14E; BSPG 2011 XLII 113, $610 \mathrm{~cm}$ below Lytoceras bed; BSPG 2011 XLII 126, $310 \mathrm{~cm}$ below Lytoceras bed; BSPG 2011 XLII 131, $290 \mathrm{~cm}$ below Lytoceras bed; BSPG 2011 XLII 135, $220 \mathrm{~cm}$ below Lytoceras bed; BSPG 2011 XLII 169, $110 \mathrm{~cm}$ below Lytoceras bed, Fig. 14A; BSPG 2011 XLII 192, $18 \mathrm{~cm}$ below Lytoceras bed.

Description. - Shell slender, turriculate; largest illustrated specimen (Fig. 14F) comprising 10 whorls including protoconch, is $3.8 \mathrm{~mm}$ high and $1.4 \mathrm{~mm}$ wide; teleoconch whorls slightly convex, with narrow subsutural ramp producing a somewhat gradate outline; whorls ornamented with strong, narrow, orthocline to opisthocyrt axial ribs; 
first one to two teleoconch whorls with 12 to 14 ribs; number of ribs increasing on fifth whorl to 18 to 20; first to second teleoconch whorl exclusively with axial ribs or axial ribs strongly dominating; later teleoconch whorls additionally ornamented with five to six weak spiral cords; mature teleoconch with dense reticulate pattern of axial ribs and spiral cords with slightly nodular intersections; adapical spiral cord with pronounced nodules producing a narrow ramp; base flat with two distinct spiral cords near edge; protoconch acutely conical, comprising 4.5 convex whorls; protoconch $0.6 \mathrm{~mm}$ high and $0.45 \mathrm{~mm}$ wide; last two larval whorls with faint rounded angulation at about one third above suture; this edge can be accentuated by a more or less distinct spiral cord; larval whorls with micro-ornament of non-collabral faint striae in the abapical portion of the whorls and dots in the adapical portion.

Remarks. - This species could be a junior synonym of P. subarmatum Ernst, 1923 (Gründel 1999c). Gründel (1999c) illustrated well-preserved material from the Opalinuston of Franconia and Swabia that is undoubtedly conspecific with the specimens from Mistelgau. The previously unknown micro-ornament of the larval shell is shown here in detail.

Occurrence. - Late Toarcian and early Aalenian.

\section{Procerithium compactum Gründel, 1999c} Figure 14H-J

*1999c Procerithium compactum sp. nov.; Gründel, p. 4, pl. 1, figs 7-9.

2009 Procerithium brandi. - Schulbert \& Nützel, p. 489, fig. 10.

Material. - 83 specimens; BSPG 2011 XLII 24-26, 5 m above Lytoceras bed.

Description. - Shell high-spired, turriculate; largest illustrated specimen (Fig. 14H) comprises ca 8 whorls including protoconch, $3.1 \mathrm{~mm}$ high, $1.2 \mathrm{~mm}$ wide; protoconch conical with somewhat larger apical angle than teleoconch; protoconch comprising four smooth whorls, $0.5 \mathrm{~mm}$ high and wide; last larval whorl exhibits a spiral cord and/or an angulation just above suture; protoconch terminates abruptly at an opisthocyrt suture; whorl face nearly straight to slightly convex with subsutural and narrow ramp producing a somewhat gradate outline; suture distinct; teleoconch whorls with pronounced, narrow, slightly opisthocline and opisthocyrt axial ribs; early teleoconch with dominating axial ribs and no or only very faint spiral cords; each whorl with 12-14 axial ribs throughout teleoconch; five spiral cords start on the second teleoconch whorl; spiral cords weaker than axial ornament; nodules present at intersections of spiral cords and axial ribs; pronounced nodules on supra- and especially strong on subsutural spiral cord which borders a narrow ramp; base flat without axial ribs; two distinct spiral cords on base near edge.

Remarks. - Based on four specimens from the Aalenian of Mistelgau, Gründel (1999c) described and figured Procerithium compactum well. According to our material, $P$. compactum is a quite abundant species in Mistelgau and occurs in the latest Toarcian and Aalenian. The aperture of this species is not yet sufficiently known. Procerithium compactum differs from $P$. brandi in having a lower larval shell that has a weaker spiral angulation or rib.

Occurrence. - Only known from Mistelgau; latest Toarcian and early Aalenian.

Superfamily Stromboidea Rafinesque, 1815

Family Aporrhaidae Gray, 1850

Remarks. - The biota of the Mistelgau clay pit is strongly dominated by the aporrhaid gastropod Toarctocera subpunctata that was recently discussed by Gründel et al. (2009). This species is one of the earliest members of the superfamily Stromboidea and the family Aporrhaidae. It can be considered as a typical soft bottom recliner with long apertural spines representing an adaptation to prevent sinking into the muddy bottom (snow shoe strategy). The Recent Aporrhais pespelecani (Linnaeus, 1758) lives burrowed in muddy substrates in a water depth from about $9 \mathrm{~m}$ to more than $130 \mathrm{~m}$. Channels with inhalant and exhalant flow connect the animal with the surrounding sediment surface where they feed on detritus. When this food source has been exploited, A. pespelecani moves to another place. The present aporrhaid species, Toarctocera subpunctata, has very long, thin apertural spines that were certainly quite fragile. Thus this gastropod was probably not a good burrower. Probably, this aporrhaid was only half burrowed or

Figure 14. A - Procerithium brandi (Walther, 1951), BSPG 2011 XLII 169, $110 \mathrm{~cm}$ below Lytoceras bed. • B-D - Procerithium brandi (Walther, 1951), BSPG 2011 XLII 192, $180 \mathrm{~cm}$ below Lytoceras bed. - E - Procerithium brandi, BSPG 2011 XLII 111, $610 \mathrm{~cm}$ below Lytoceras bed. - F - Procerithium brandi, BSPG 2011 XLII 131, $290 \mathrm{~cm}$ below Lytoceras bed. • G - Procerithium brandi, BSPG 2011 XLII $135,220 \mathrm{~cm}$ below Lytoceras bed. $\bullet \mathrm{H}, \mathrm{I}$ - Procerithium compactum, BSPG 2011 XLII 24, 5 m above Lytoceras bed. • J - Procerithium compactum, BSPG 2011 XLII $25,5 \mathrm{~m}$ above Lytoceras bed. 


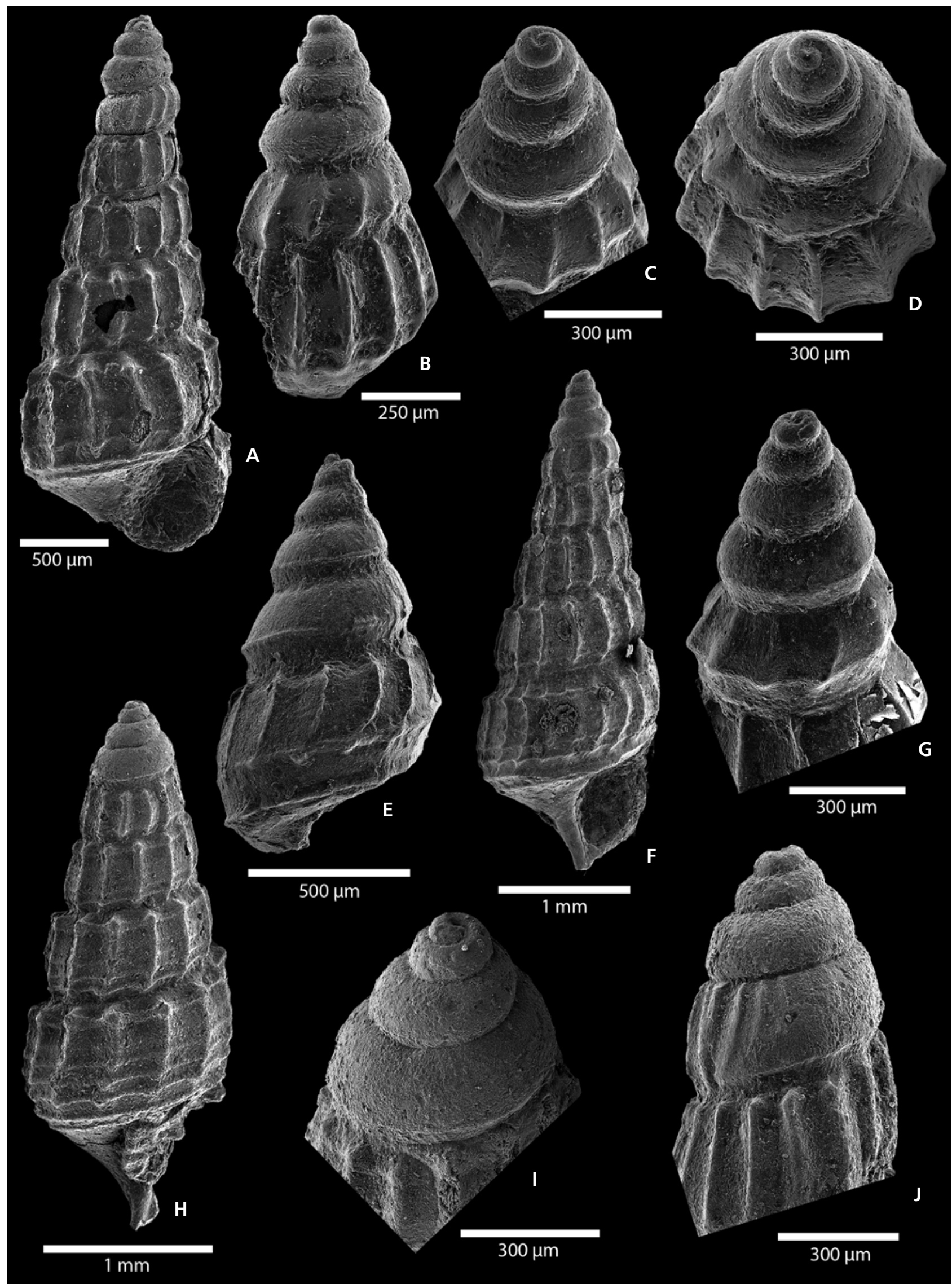




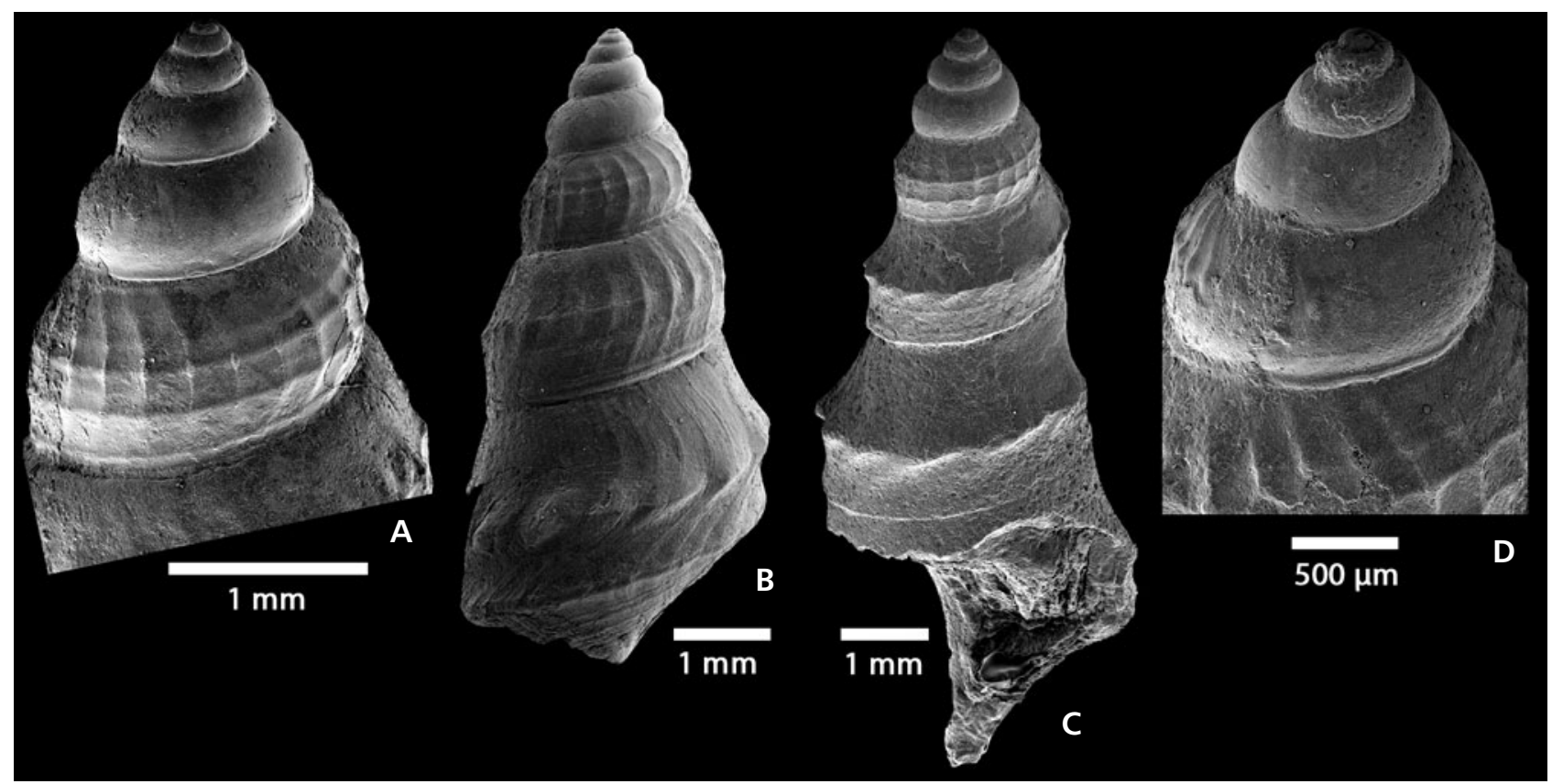

Figure 15. A, B - Toarctocera subpunctata (zu Münster in Goldfuss, 1844), BSPG 2011 XLII 60, surface collection. • C - Toarctocera subpunctata, BSPG 2011 XLII 55, surface collection. • D - Toarctocera subpunctata, BSPG 2011 XLII 58, surface collection.

epibenthic and the very long spines were more an adaptation to prevent sinking into the soft substrate (Etter 1996).

\section{Genus Toarctocera Gründel, Nützel \& Schulbert, 2009}

Type species. - Rostellaria subpunctata zu Münster in Goldfuss, 1844, Toarcian/Aalenian transition, S Germany.

\section{Toarctocera subpunctata [Münster, 1844 in Goldfuss (1844)]}

Figures 15A-D, 16

*1844 Rostellaria subpunctata sp. nov.; Zu Münster in Goldfuss, p. 16, pl. 169, fig. 7a, b.

2009 Toarctocera subpunctata. - Gründel, Nützel \& Schulbert, p. 536, figs 2, 3 (here more synonymy, see also Gründel 1998).

Material. - More than 1000 specimens; BSPG 2011 XLII 37-42, $5 \mathrm{~m}$ above Lytoceras bed; BSPG 2011 XLII 55, surface collection; BSPG 2011 XLII 58, 59, surface collection; BSPG 2011 XLII 60, surface collection; BSPG 2011 XLII 96, $530 \mathrm{~cm}$ below Lytoceras bed; BSPG 2011 XLII 99, $530 \mathrm{~cm}$; BSPG 2011 XLII 100, $530 \mathrm{~cm}$; BSPG 2011 XLII $107,320 \mathrm{~cm}$.

Description (as in Gründel et al. 2009). - Shell highspired, slender; specimen illustrated in Fig. $15 \mathrm{C}$ is $8.5 \mathrm{~mm}$ high and $3.7 \mathrm{~mm}$ wide; largest known shells measure a few centimetres in height; protoconch conical, of about five whorls, $1.3 \mathrm{~mm}$ high and $1.2 \mathrm{~mm}$ wide; protoconch whorls smooth, convex; protoconch with suprasutural spiral cord emerging at suture; first one to two teleoconch whorls with reticulate ornament of orthocline and distinctly opisthocyrt axial ribs and two to three weak spiral cords; about 20 to 22 axial ribs per whorl; ribs fade on the second teleoconch whorl; whorls somewhat angulated at spiral cords, which are situated at about mid-whorl and half way between this spiral cord and abapical suture; upper spiral cord and angulation becoming strong and keel-like on mature teleoconch whorls and shifts in abapical direction so that it is finally at about one third of whorl height; keel bears elongated, oblique nodes numbering from 16 to about 20 per whorl; at the same time other spiral cords on whorl face are reduced so that the whorl face of the mature teleoconch shows only a strong, nodular keel with concave whorl sides above and below; additional spiral cord emerging at the abapical suture forming angular transition to base; growth lines of mature teleoconch whorls strongly parasigmoidal; outer lip of the aperture of adult specimens is extended to a rectangular plate on which both keels extend as strong ribs. They protrude as two long spines (usually broken off); adapical spine is bending adapically until it is parallel to the shell axis; second outer lip spine runs nearly straight in direction about $130^{\circ}$ from axis on adapical side; columellar rostrum is bent to the left (in apertural view) adapically until it is almost parallel to the shell axis.

Remarks. - Toarctocera subpunctata is the most abundant benthic gastropod in Mistelgau. It is present throughout the 
section except of a few samples. Thus, T. subpunctata is present in the late Toarcian and in the Aalenian. Commonly, this gastropod forms clusters with abundant shells. Undoubtedly, T. subpunctata was a major component of the ecosystem. Shells from washed residues never have preserved apertural spines but these spines can be found isolated. Complete specimens with preserved apertural spines were reported by Brösamlen (1909), Hägele (1997) and Gründel et al. (2009). The spines are comparatively thin and long (Fig. 16).

Occurrence. - Late Toarcian, early Aalenian, S Germany (Swabia, Franconia), France, N Switzerland (see Gründel et al. 2009).

\section{Unidentified stromboid}

Figure 17A-C

Material. - BSPG 2011 XLII 148, $150 \mathrm{~cm}$ below Lytoceras bed.

Description. - Shell high-spired, with turriculate teleoconch and blunt protoconch; illustrated specimen $3.1 \mathrm{~mm}$ high, $1.9 \mathrm{~mm}$ broad; shell comprises somewhat more than 2 protoconch whorls and 3 to 4 teleoconch whorls; protoconch smooth, low-spired, $0.27 \mathrm{~mm}$ high, $0.58 \mathrm{~mm}$ wide; first protoconch whorl flat; first teleoconch whorls strongly convex with median angulation with very strong nodules, numbering 12-14 per whorl; nodose spiral crest forms a concave subsutural ramp; last preserved whorl smooth, without nodules but with distinct angulation in abapical position.

Remarks. - Although the preservation is not ideal, this specimen shows a unique character combination. Especially the ontogenetic change of the teleoconch from having a median crest with strong nodes to being smooth with an angulation low on the whorls is to our knowledge unique in Gastropoda. It is evident that this specimen represents a caenogastropod. We leave the family assignment open although a stromboid and aporrhaid relation seems possible. Diatrypesis kurushini Kaim, 2004 described from the Valanginian of Poland resembles our material. The present species could be a Jurassic relative of this Cretaceous species. However, it could also represent a juvenile aporrhaid.

Occurrence. - Early Aalenian.

Family Strombidae Rafinesque, 1815

\section{Genus Ueckeritzella Gründel, 1998a}

Type species. - Ueckeritzella mothsi Gründel, 1998a, late Bajocian, early Bathonian, NE Germany.

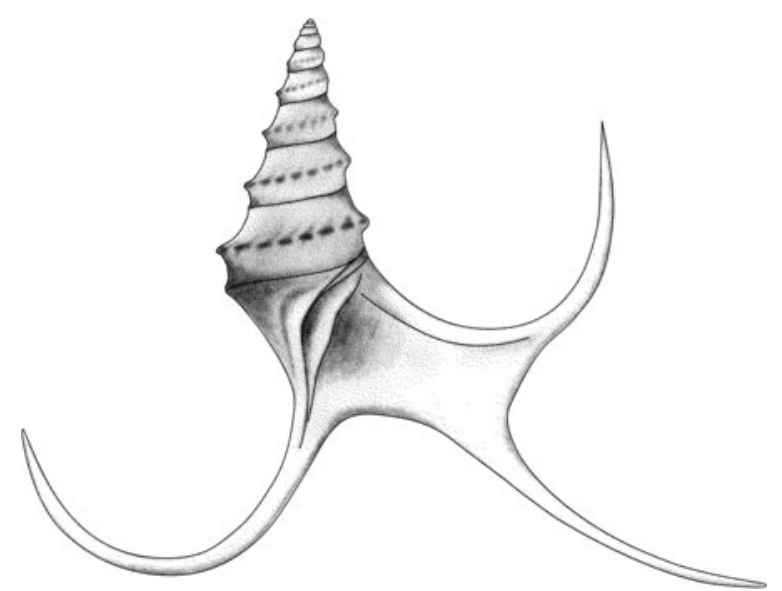

Figure 16. Toarctocera subpunctata reconstruction with spines.

\section{Ueckeritzella sp. 1}

Figure 17D, E

Material. - Two specimens, BSPG 2011 XLII 200, $0 \mathrm{~cm}$, Fig. 17D, E.

Description. - Illustrated specimen has 3.7 protoconch whorls and 0.5 teleoconch whorls; shell height $1.4 \mathrm{~mm}$ and width $1.2 \mathrm{~mm}$; protoconch trochospiral, conical, $0.85 \mathrm{~mm}$ high and $0.64 \mathrm{~mm}$ wide; protoconch whorls smooth convex; suture distinct; transition from protoconch to teleoconch defined by gradual onset of axial ribs; teleoconch whorl shows about 20 (extrapolated) opisthocyrt axial ribs; axial ribs bend towards aperture on abapical portion; spiral ornamentation absent on whorl face; boundary to base is formed by a strong spiral cord angulating the whorl; this spiral cord is ornamented by very faint thread-like spiral structures; base slightly convex and smooth.

Remarks. - This juvenile specimen is of unknown affinity. It resembles Ueckeritzella mothsi Gründel 1998a from the late Bajocian to early Bathonian of NE Germany. However, this species has distinct spiral cords on the whorl face of the teleoconch including the early teleoconch that are absent in the present specimen. The stromboid affinity of the present specimen is not beyond doubt.

Occurrence. - Late Toarcian and early Aalenian.

\section{Ueckeritzella sp. 2}

Figure 17G-I

Material. - 3 specimens; BSPG 2011 XLII 27-28, 5 m above Lytoceras bed.

Description. - Juvenile shell fragment consisting of larval shell and 1.5 teleoconch whorls; illustrated specimen is 


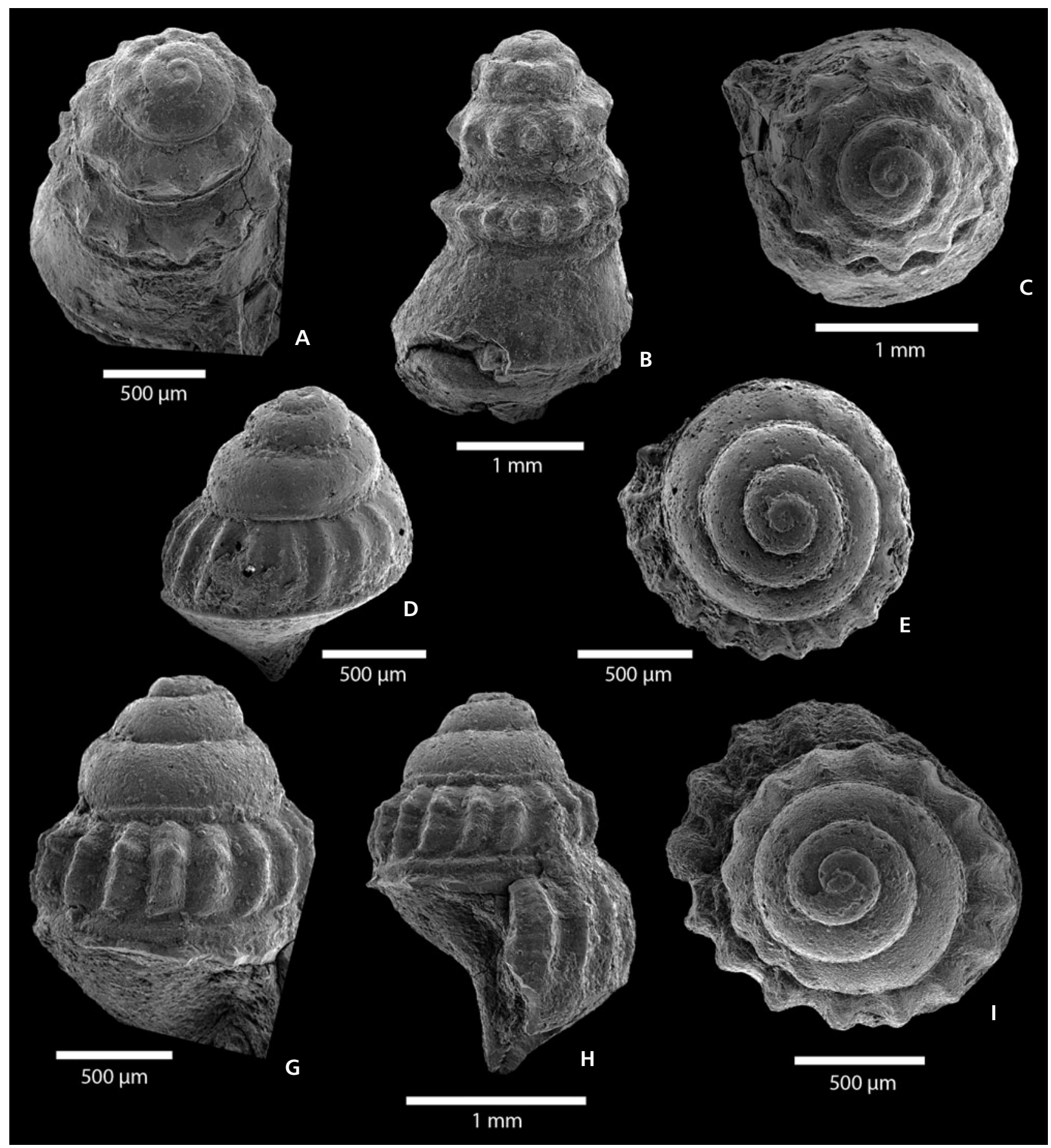

Figure 17. A-C - unident. stromboid, BSPG 2011 XLII 148, $150 \mathrm{~cm}$ below Lytoceras bed. • D, E- Ueckeritzella sp. 1, BSPG 2011 XLII $200,0 \mathrm{~cm}$ below Lytoceras bed. • I- Ueckeritzella sp. 2, BSPG 2011 XLII 27, $5 \mathrm{~m}$ above Lytoceras bed. • G, H - Ueckeritzella sp. 2, BSPG 2011 XLII $28,5 \mathrm{~m}$ above Lytoceras bed.

$2.1 \mathrm{~mm}$ high and $1.5 \mathrm{~mm}$ wide; protoconch broadly conical, consisting of 3.3 whorls, $0.5 \mathrm{~mm}$ high, $0.9 \mathrm{~mm}$ wide; first whorl flattened; protoconch whorls convex with impressed suture, smooth; teleoconch with smaller apical angle than protoconch; teleoconch with strong, broad, rounded opisthocyrt axial ribs; last preserved teleoconch whorl with 16 axial ribs; ribs are broader than interspaces; whorls ornamented with broad spiral cords, much weaker than axial ribs numbering 5 to 6 ; whorls angulated at adapical and abapical spiral cords; broad spirally elongated nodes 


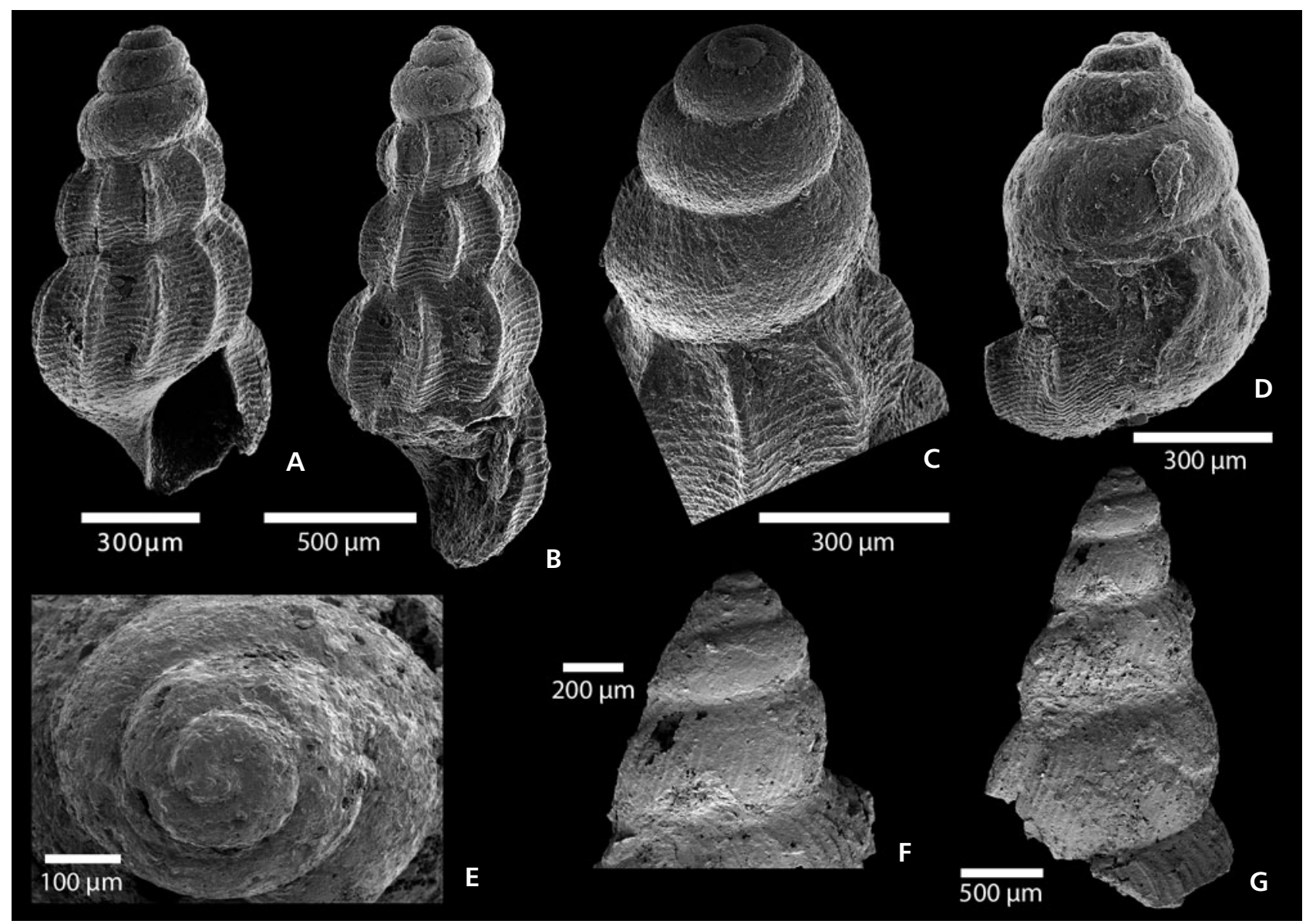

Figure 18. A - Palaeorissoina maeuseri Gründel, 1999a, BSPG 2011 XLII 208, $6 \mathrm{~m}$ above Lytoceras bed. • B - Palaeorissoina maeuseri, BSPG 2011 XLII 32, $5 \mathrm{~m}$ above Lytoceras bed. $\bullet$ C - Palaeorissoina maeuseri, BSPG 2011 XLII 29, $5 \mathrm{~m}$ above Lytoceras bed. $\bullet$ D - Palaeorissoina maeuseri, BSPG 2011 XLII 68, $320 \mathrm{~cm} 5$ m below Lytoceras bed. • E, F, G - Bralitzia sp., BSPG 2011 XLII 91, 40-60 cm below Lytoceras bed.

at intersections of axial ribs and spiral cords; teleoconch whorls seemingly adpressed forming spiral bulge at suture; this bulge shows traces of up to 5 spiral threads (not visible in figures).

Remarks. - Although quite characteristic, this specimen is too fragmentary for a safe identification. It is clearly a caenogastropod as is indicated by the multi-whorled larval shell. The broad and smooth larval shell resembles that of Ueckeritzella as reported by Gründel (1998a, pl. 7, figs 1-4). This genus also has a teleoconch ornament of dominating axial ribs and weaker spiral cords that is typical of Ueckeritzella. Ueckeritzella sp. 2 differs from Ueckeritzella sp. 1 by having spiral cords and much stronger axial ribs on the teleoconch whorls.

Occurrence. - Early Aalenian.

Superfamily Rissooidea Gray, 1847

Family Palaeorissoinidae Gründel \& Kowalke, 2002

\section{Genus Palaeorissoina Gründel, 1999a}

Type species. - Palaeorissoina compacta Gründel, 1999a, Middle Jurassic, NE Germany.

\section{Palaeorissoina maeuseri Gründel, 1999a}

Figure 18A-D

*1999a Palaeorissoina maeuseri sp. nov.; Gründel, p. 98, pl. 2, figs $1-3$.

2007a Palaeorissoina maeuseri. - Gründel, p. 240, fig. 1D.

2009 Palaeorissoina maeuseri. - Schulbert \& Nützel, p. 386 , fig. 8 .

Material. - 143 specimens; BSPG 2011 XLII 29-33, 5 m above Lytoceras bed; BSPG 2011 XLII 68, 71, $320 \mathrm{~cm}$ below Lytoceras bed; BSPG 2011 XLII 153, $150 \mathrm{~cm}$ below Lytoceras bed; BSPG 2011 XLII 208, 6 m above Lytoceras bed, Fig. 18A; BSPG 2011 XLII 218, $6 \mathrm{~m}$ above Lytoceras bed.

Description. - Shell small, high-spired, slender; largest 
illustrated specimen consists of 3.5 teleoconch whorls, is $1.8 \mathrm{~mm}$ high and $0.7 \mathrm{~mm}$ wide; teleoconch whorls convex, ornamented with strong orthocline to slightly opisthocyrt and slightly opisthocline axial ribs; axial ribs narrow, sharp, separated by wide interspaces; about 10 axial ribs per whorl; ribs do not continue onto base; teleoconch ornamented with numerous fine, equally spaced spiral threads which also cover the base; base convex; suture distinct; protoconch high-spired, dome-shaped with somewhat flattened apex; protoconch comprising about four smooth, distinctly convex whorls; protoconch about $0.3 \mathrm{~mm}$ high and wide; larval shell terminates abruptly at sinusigera ridge.

Remarks. - Palaeorissoina maeuseri is a small species and only a single specimen was found by surface collecting. However, numerous specimens were recovered from washed residues from the Mistelgau clay pit, especially in the Aalenian, where it forms the most abundant species of the gastropod assemblage. Only a few specimens are present in samples from the late Toarcian. The smooth protoconch of $P$. maeuseri indicates planktotrophic larval development. Gründel (1999a) reported more than 100 specimens from the Aalenian of Kremmelsdorf east of Bamberg (Upper Franconia, South Germany). Gründel (1999a, 2007a) also noted that Palaeorissoina maeuseri is present with a few specimens in the samples of Walther (1951) from Northern Germany (near the Harz Mountains) and in a boring from North Germany (150 specimens, bore Aulosen).

Occurrence. - Latest Toarcian and early Aalenian.

Family Iravadiidae Thiele, 1928

\section{Genus Bralitzia Gründel, 1998a}

Type species. - Bralitzia foersteri Gründel, 1998a from the Middle Jurassic, NE Germany.

\section{Bralitzia sp.}

Figure $18 \mathrm{E}-\mathrm{G}$

Material. - BSPG 2011 XLII 91, 40-60 cm below Lytoceras bed.

Description. - High-spired shell comprising about 3 teleoconch whorls; illustrated specimen is $2.7 \mathrm{~mm}$ high and $1.4 \mathrm{~mm}$ wide; teleoconch whorls convex; whorl face covered with numerous, opisthocyrt sigmoidal axial ribs; ribs relatively weak having the character of strengthened growth lines; suture distinct; aperture not preserved; protoconch $0.4 \mathrm{~mm}$ high and $0.5 \mathrm{~mm}$ broad, consisting of about 3.5 smooth, distinctly convex whorls.

Remarks. - Bralitzia sp. resembles B. foersteri (type species of Bralitzia) from the Middle Jurassic of NE-Germany. However, B. foersteri has fewer ribs per whorl and the teleoconch whorls are somewhat adpressed. The present specimen probably represents an undescribed species but our material is not sufficient for a formal description.

Occurrence. - Early Aalenian.

\section{Genus Kalchreuthia Gründel \& Nützel, 1998}

Type species. - Pseudomelania frankei Kuhn, 1936, Pliensbachian, Amaltheenton Formation, Franconia.

Kalchreuthia leyerbergensis (Krumbeck, 1925)

Figure 19A-I

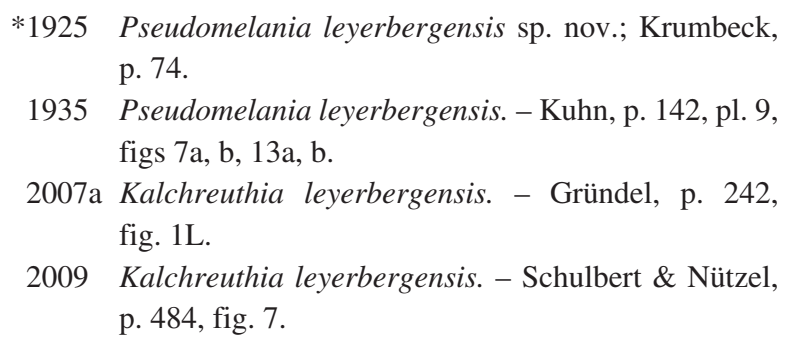

Material. - 135 specimens; BSPG 2011 XLII 149, $150 \mathrm{~cm}$ below Lytoceras bed, Fig. 19C, BSPG 2011 XLII 64, $320 \mathrm{~cm}$ below Lytoceras bed, BSPG 2011 XLII 76, $140 \mathrm{~cm}$ below Lytoceras bed, BSPG 2011 XLII $125,310 \mathrm{~cm}$ below Lytoceras bed, Fig. 19F, I; BSPG 2011 XLII 151, $150 \mathrm{~cm}$ below Lytoceras bed, BSPG 2011 XLII 167, $110 \mathrm{~cm}$ below Lytoceras bed; BSPG 2011 XLII 185, $460 \mathrm{~cm}$ below Lytoceras bed; BSPG 2011 XLII 189, $180 \mathrm{~cm}$ below Lytoceras bed; BSPG 2011 XLII 196, $510 \mathrm{~cm}$ below Lytoceras bed, Fig. 19D, E.

Description. - Small, high-spired turriculate shell, comprising about five whorls; shell 2 to $3 \mathrm{~mm}$ high, 1 to $1.3 \mathrm{~mm}$ wide; first 4 whorls (presumably larval shell) distinctly convex, increasing rapidly in diameter; protoconch orthostrophic; initial whorl nearly planispiral; transition between

Figure 19. A, G, H - Kalchreuthia leyerbergensis (Krumbeck, 1925), BSPG 2011 XLII 185, $460 \mathrm{~cm}$ below Lytoceras bed. • B - Kalchreuthia leyerbergensis, BSPG 2011 XLII 149, $150 \mathrm{~cm}$ below Lytoceras bed. • C - Kalchreuthia leyerbergensis, BSPG 2011 XLII 64, $320 \mathrm{~cm}$ below Lytoceras 

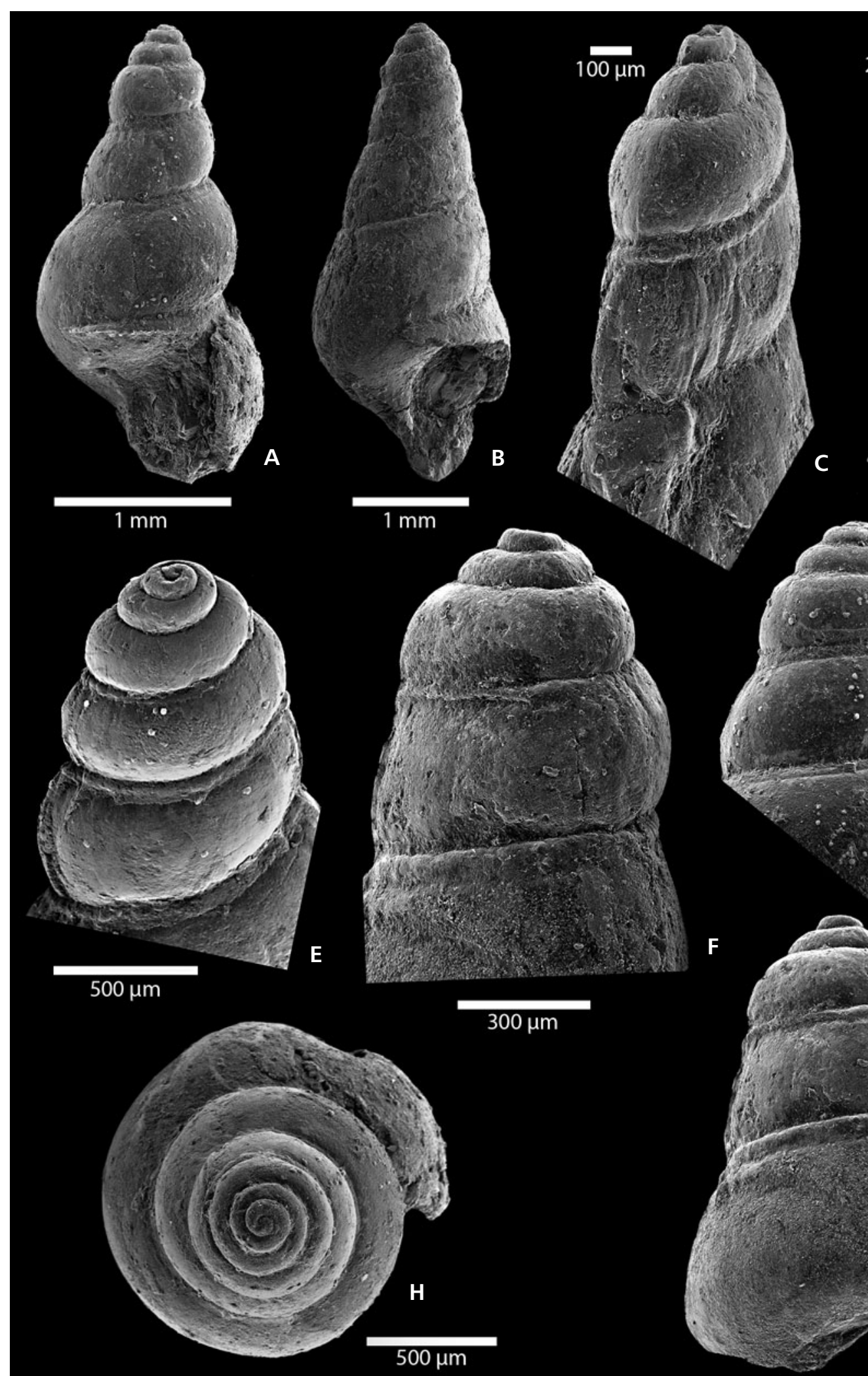

$300 \mu \mathrm{m}$
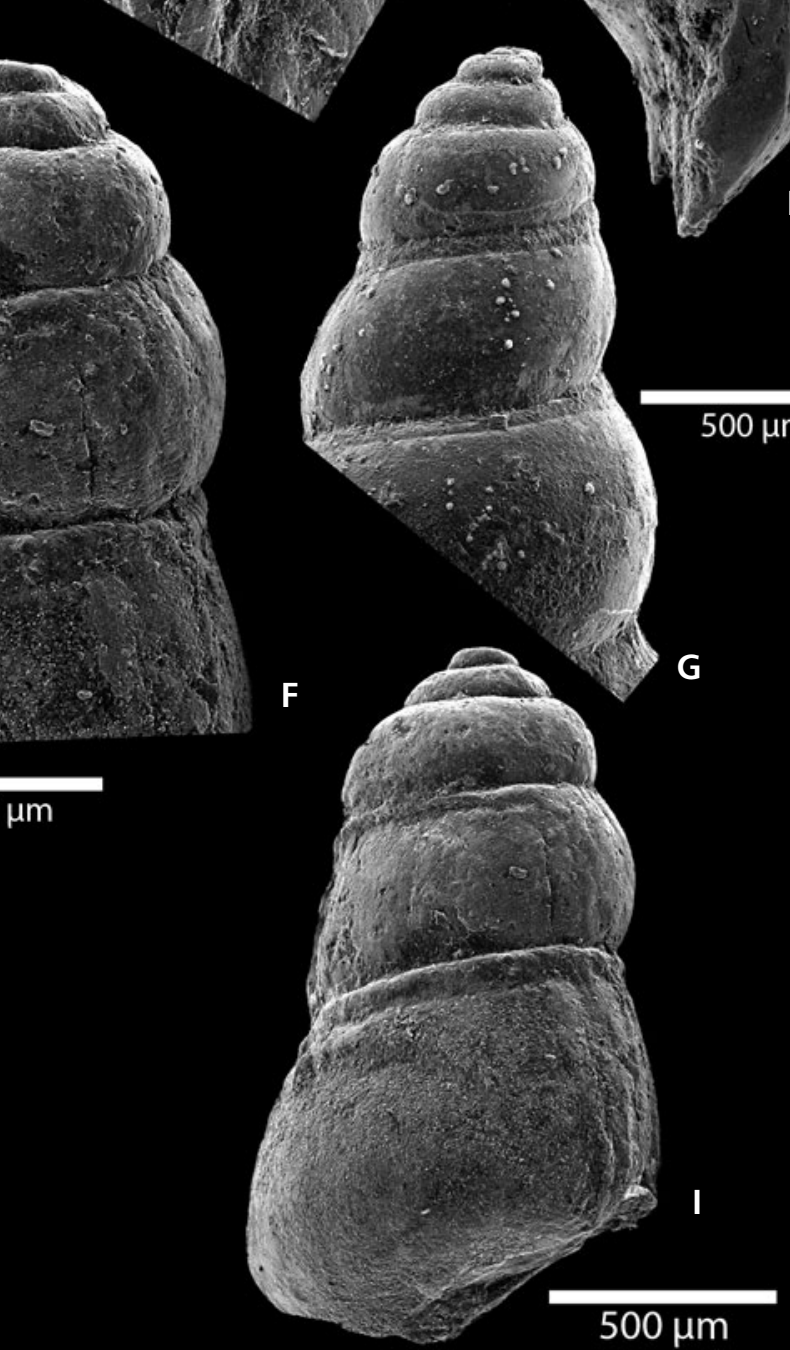

bed. • D, E - Kalchreuthia leyerbergensis, BSPG 2011 XLII 196, $510 \mathrm{~cm}$ below Lytoceras bed. • F, I - Kalchreuthia leyerbergensis, BSPG 2011 XLII $125,310 \mathrm{~cm}$ below Lytoceras bed. 
protoconch and teleoconch not well preserved; starting with fourth whorl, increase is slower indicating teleoconch onset; teleoconch whorls high, adpressed with a more or less distinct subsutural collar and a spiral furrow below this collar; shell smooth with faint opisthocyrt growth lines; aperture poorly preserved, somewhat higher than wide.

Remarks. - Pseudomelania leyerbergensis was introduced and described by Krumbeck (1925). However, this author did not illustrate the species nor was a holotype designated. The whereabouts of the type material is unknown. Kuhn (1935) studied the material of Krumbeck and illustrated specimens, which agree well with our material. Krumbeck (1925) reported some hundred specimens from the Leyerer Berg near Hetzles, about $36 \mathrm{~km} \mathrm{SW}$ of Mistelgau.

Because of its small size, Kalchreuthia leyerbergensis can be found almost exclusively by washing and sieving. The genus Kalchreuthia is also abundant in the Pliensbachian of Franconia (K. frankei, e.g. Nützel \& Kiessling 1997, Gründel \& Nützel 1998). Many of the present specimens from Mistelgau exhibit a subsutural furrow, which was also reported as a casual character by Krumbeck (1925) and Kuhn (1935). Kuhn (1935) noted single specimens with spiral ornamentation from Krumbeck's material. We could not observe this character in the present material. Gründel (2007a) reported K. leyerbergensis from the early Aalenian of Northern Germany. However, this material is lacking a subsutural furrow. The present material from Mistelgau exhibits a considerable intraspecific variability. The teleoconch whorls vary from distinctly convex to almost straight. A collar and a subsutural furrow may be distinct to absent. A clear transition from the proto- to the teleoconch was not observed but is seems obvious that the larval shell is of the planktotrophic type with about 4 whorls. The larval shell is distinctly broader (larger apical angle) than the teleoconch.

Occurrence. - Late Toarcian and early Aalenian.

Superfamily Xenophoroidea Troschel, 1852

Family Lamelliphoridae Korobkov, 1960

(in Pchelintsev \& Korobkov)

\section{Genus Lamelliphorus Cossmann, 1916}

Type species. - Trochus ornatissimus (d'Orbigny, 1853), Middle Jurassic, France.

Lamelliphorus flexuosus (zu Münster in Goldfuss, 1844) Figure 20A-D

1844 Trochus flexuosus sp. nov.; Zu Münster in Goldfuss, p. 53 , pl. 179 , fig. 8 .
1901 Onustus flexuosus. - Schlosser, p. 545.

1935 Onustus flexuosus. - Kuhn, p. 139, pl. 9, figs 16, 39.

1997 Lamelliphorus flexuosus. - Hägele, p. 98, figure upper left.

Material. - One specimen from the Urwelt-Museum Oberfranken, Bayreuth, BT 006298.00, Nedensdorf near Banz (occurs also in Mistelgau according to S. Eggmaier, oral communication 2012).

Description. - Shell broad, low-spired, conical, xenophorid-like; illustrated specimen is $13 \mathrm{~mm}$ high and $21 \mathrm{~mm}$ wide; shell comprises about 4.5 whorls; apical angle of shell about $100^{\circ}$; whorl face slightly concave; suture distinct; whorls with narrow opisthocline, somewhat opisthocyrt and irregularly curving ribs; 23 ribs present on last whorl; transverse ornamentation overprints suture producing undulating line; whorls with frill at periphery; base of whorls convex but concave near frill; base with strongly prosocline-feebly oristhocyrt growth-lines and numerous adumbilical spiral threads; narrow umbilicus present perhaps with callus; aperture oval, wider than high.

Remarks. - Lamelliphorus flexuosus is a rare species in the late Toarcian and early Aalenian of Franconia. To our knowledge the species has not been reported from elsewhere.

Occurrence. - Late Toarcian and early Aalenian.

Superfamily Purpurinoidea Zittel, 1895

Family Purpurinidae Zittel, 1895

\section{Genus Purpurina d'Orbigny, 1850}

Type species. - Turbo bellona d'Orbigny, 1850, Bathonian, France.

\section{Purpurina sp.}

Figure 21D

?1909 Purpurina opalina. - Brösamlen, p. 247, pl. 19, fig. 37.

?1935 Purpurina ex aff. elaborata Morris \& Lycett. - Kuhn, p. 136, pl. 10, fig. 22.

Material. - One specimen from Mistelgau, UrweltMuseum Oberfranken, Bayreuth, collection Eggmaier.

Description. - Shell broadly ovate, with gradate spire; illustrated specimen is $9 \mathrm{~mm}$ high and $6 \mathrm{~mm}$ wide; shell comprises about 5 whorls; apex poorly preserved; whorls convex, with a broad, slightly inclined ramp; edge between 


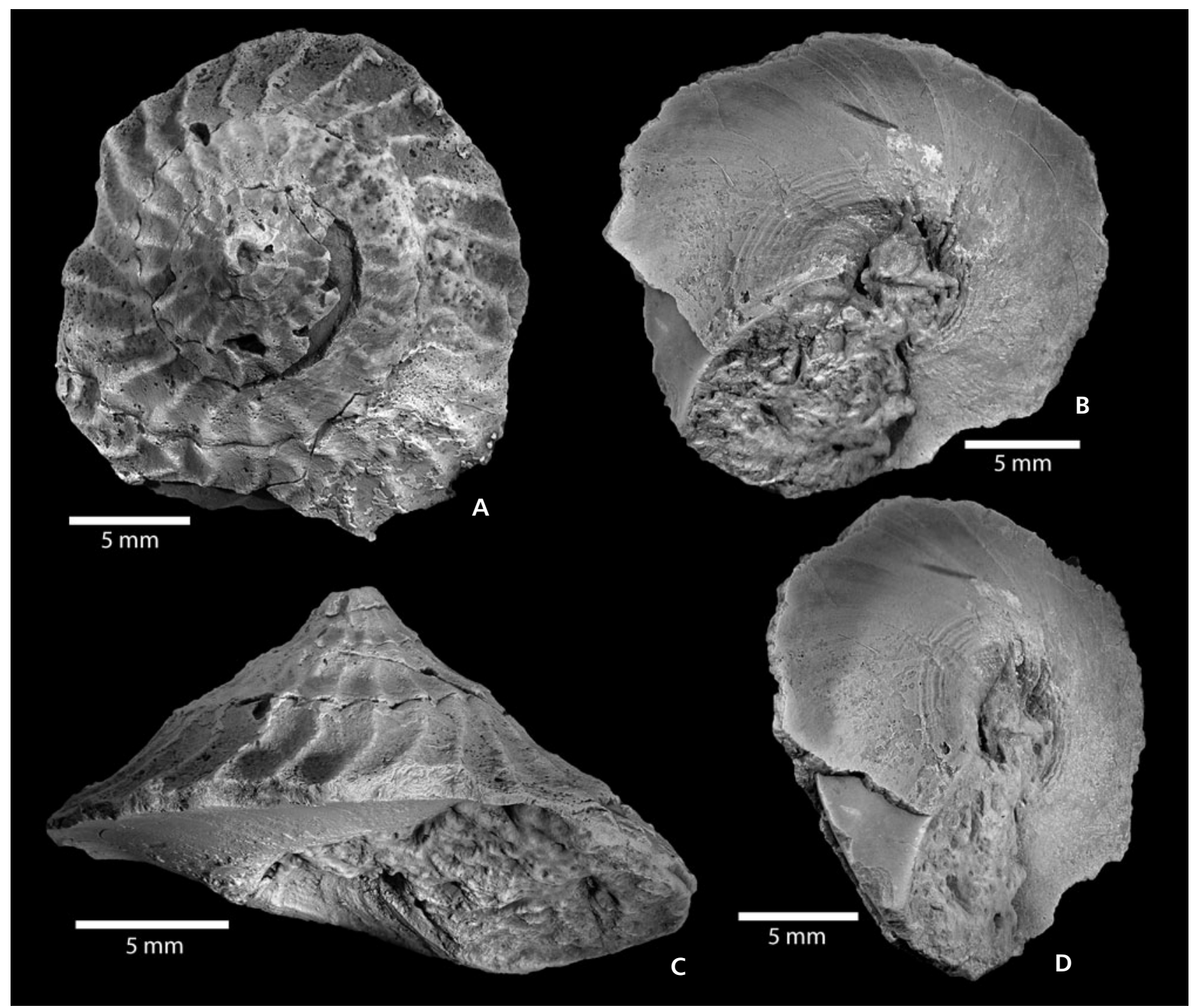

Figure 20. Lamelliphorus flexuosus (zu Münster in Goldfuss, 1844), Urwelt-Museum Oberfranken, Bayreuth, BT 006298.00, Nedensdorf near Banz.

ramp and outer whorl face sharply angular; whorls including ramp ornamented with strong, fold-like orthocline ribs; whorls below ramp and base ornamented with equally spaced, uniform spiral cords; spiral cords absent on ramp; axial ribs fade away on base; 5 spiral cords on outer whorl face; additional spiral cords on convex base; intersections of axial ribs and spiral cords not nodular; adapical spiral positioned on edge of ramp; about 16 axial ribs present on last whorl; ribs forming strongly angular pattern on the ramp; aperture not well-preserved.

Remarks. - Members of the genus Purpurina are rare in the Toarcian/Aalenian of Franconia. Brösamlen (1909) reported a specimen from the Aalenian of Baden-Württemberg. However, this specimen is poorly documented; it is seemingly much broader and the ramp is much more inclined. Kuhn (1935) reported a specimen from the Toarcian/Aale- nian of Franconia (Trimeusel), which he identified as $P$. ex aff. elongata Morris \& Lycett. This specimen is poorly documented. It seems to have fewer axial ribs than the specimen at hand.

Occurrence. - Early Aalenian.

Suborder Neogastropoda Wenz, 1938

Family Maturifusidae Gründel, 2001b

(= Pseudotritoniinae Golikov \& Starobogatov, 1987,

see Nützel 2010)

\section{Genus Maturifusus Szabó, 1983}

Type species. - Maturifusus densicostatus Szabó, 1983, Bajocian, Hungary. 


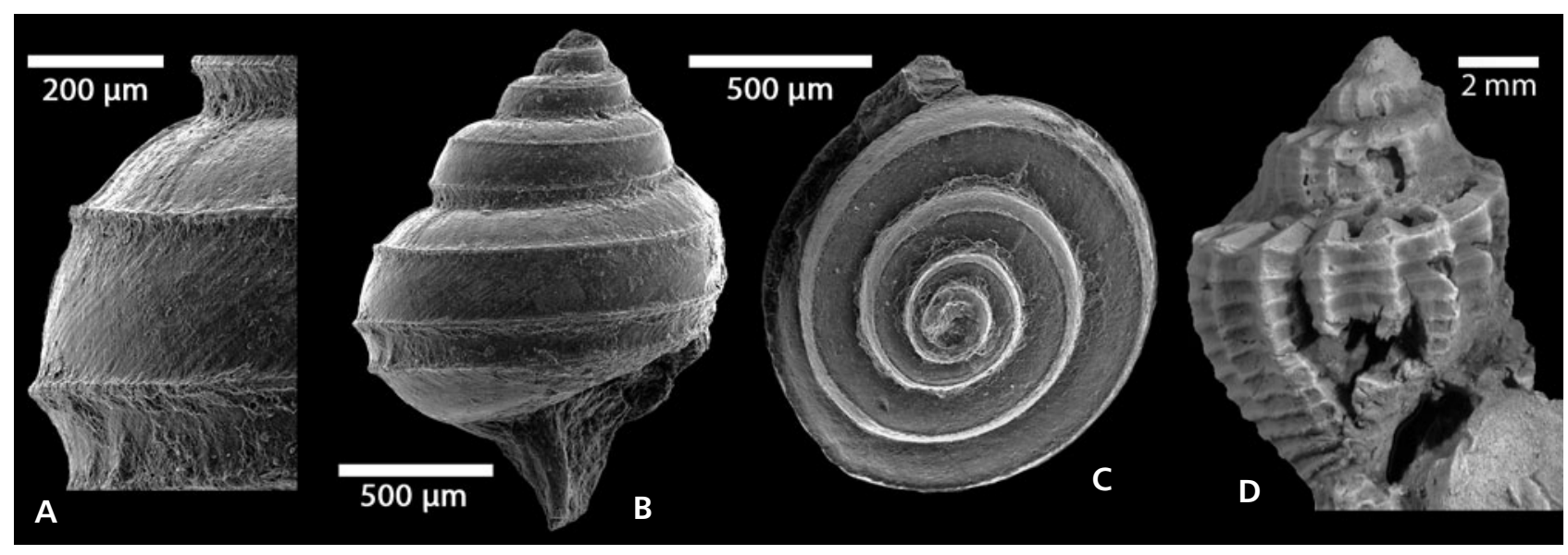

Figure 21. A-C-Maturifusus sp., BSPG 2011 XLII 122, $310 \mathrm{~cm}$ below Lytoceras bed. • D - Purpurina sp., Mistelgau, Urwelt-Museum Oberfranken, Bayreuth, Collection Eggmaier.

\section{Maturifusus sp.}

Figure 21A-C

Material. - Six specimens; BSPG 2011 XLII 122, $310 \mathrm{~cm}$, Fig. 21A-C; BSPG 2011 XLII 162, $500 \mathrm{~cm}$.

Description. - Conoidal, gradate larval shell with rounded angulation on whorls; $1.6 \mathrm{~mm}$ high and $1.2 \mathrm{~mm}$ broad; 4.5 whorls are preserved; first half whorl of the protoconch is poorly preserved; whorls convex; suture distinct; whorls smooth except two sharp spiral cords; adapical spiral cord runs on angulation at adapical first quarter of whorl; abapical spiral cord somewhat above suture with slightly increasing distance to suture during growth; whorl face of last whorl shows faint sigmoidal opisthocline growth lines between spiral cords; last whorl shows third cord at edge of base and whorl face, covered by succeeding whorls in previous whorls.

Remarks. - The present shell resembles the larval shell of Maturifusus szaboi Schröder, 1995 from the late Aalenian of Hambühren (N Germany). However, the larval shell of M. szaboi seems to be less gradate and the spiral cords are weaker to almost absent.

Occurrence. - Late Toarcian.

Subclass Heterobranchia Burmeister, 1837

Superfamily Mathildoidea Dall, 1889

Family Mathildidae Dall, 1889

\section{Genus Tricarilda Gründel, 1973}

Type species. - Mathilda (Tricarilda) plana Gründel, 1973, Callovian, NW Poland.
Tricarilda sp.

Figure 22E-H

2009 Tricarilda sp. - Schulbert \& Nützel, p. 494, fig. 15.

Material. - BSPG 2011 XLII 34, 5 m above Lytoceras bed; BSPG 2011 XLII 205, $6 \mathrm{~m}$ above Lytoceras bed, Fig. 22E-H.

Description. - Largest present specimen is $1 \mathrm{~mm}$ high and $0.5 \mathrm{~mm}$ wide, consisting of protoconch and two teleoconch whorls; teleoconch high-spired; suture distinct; whorl face angulated somewhat below mid-whorl; teleoconch whorls with three spiral cords (primary spiral cords); middle spiral cord strongest, situated at distinct angulation (keel); adapical spiral cord weaker, just below suture; abapical cord about as strong as adapical one, situated between keel and abapical suture, somewhat closer to suture; fourth spiral cord at abapical suture, covered by succeeding whorl; base slightly convex with at least one spiral cord; last preserved whorl exhibits $c a 40$ faint, opisthocline axial threads, producing a reticulate pattern with spiral cords; protoconch heterostrophic, medioaxial with $0.4 \mathrm{~mm}$ diameter; last protoconch whorl with distinct axial (radial) ribs on subsutural and circumumbilical portions but fading on periphery.

Remarks. - Tricarilda schmidti as reported by Gründel (2007a) from Northern Germany resembles Tricarilda sp. However, T. schmidti lacks ribs on the protoconch. Gründel (2007a) illustrated Kuhn's (1935) type specimen (holotype by monotypy) of Promathildia krumbecki from Mistelgau (Gründel 2007a, fig. 4L-M; Kuhn, 1935, pl. 9, fig. 2a, b). Accordingly, Promathildia krumbecki differs from Tricarilda sp. in being more slender and in having a much more prominent spiral cord below the main angulation of the whorls.

Occurrence. - Late Toarcian and early Aalenian. 


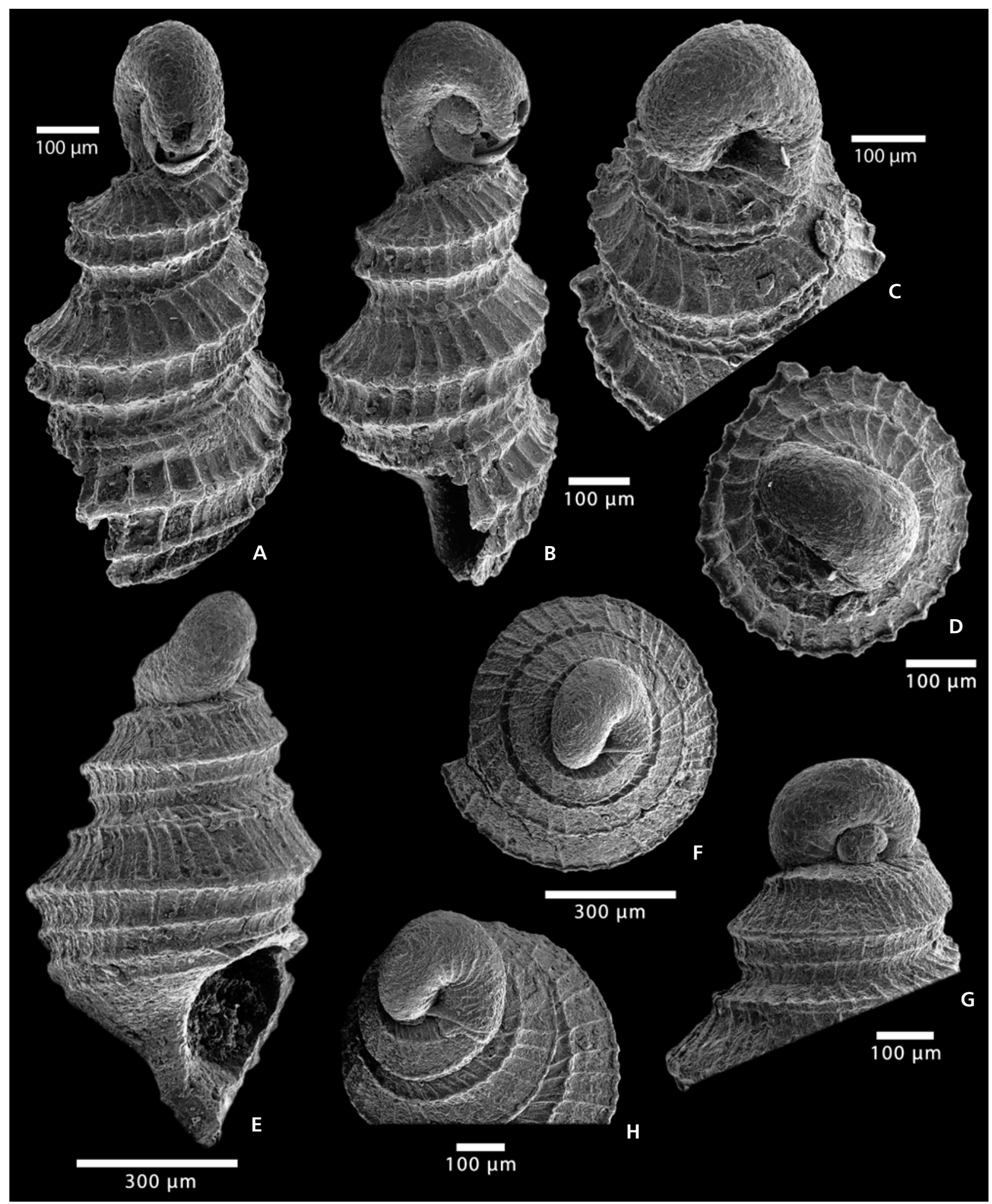

Figure 22. A-D - Promathildia krumbecki (Kuhn, 1935), BSPG 2011 XLII 214, 6 m above Lytoceras bed. • E-H - Tricarilda sp., BSPG 2011 XLII 205, $6 \mathrm{~m}$ above Lytoceras bed. 


\section{Genus Jurilda Gründel, 1973}

Type species. - Mathilda (Jurilda) crasova Gründel, 1973 [= subjective junior synonym of Promathildia (Teretrina) concava Walther, 1951].

\section{Jurilda zapfi Schulbert, Nützel \& Gründel sp. nov. Figure 23A-G}

2007a Promathilda sp. nov. - Gründel, p. 242, fig. 1M, N.

Types. - Holotype BSPG 2011 XLII 121, $310 \mathrm{~cm}$, Fig. 23A, D, E, F; 4 paratypes: BSPG 2011 XLII 63, $320 \mathrm{~cm}$ below Lytoceras bed, BSPG 2011 XLII 212, $600 \mathrm{~cm}$ above Lytoceras bed, Fig. 23B, C, G; BSPG 2011 XLII 216, $600 \mathrm{~cm}$ above Lytoceras bed; one paratype from North Germany (Gründel 2007a, fig. 1M-B).

Type horizon and locality. - Late Toarcian/early Aalenian, Opalinuston Formation, clay pit near Mistelgau, Oberfranken, Germany.

Material. - Five type specimens.

Etymology. - In honour of Helmut Zapf (Creußen), Naturwissenschaftliche Gesellschaft Bayreuth (Natural History Society Bayreuth) for introducing us to the Mistelgau clay pit and for his great support.

Diagnosis. - Jurilda species with slender, acutely conoidal teleoconch with markedly angular whorls and straight flanks; teleoconch whorls with two spiral cords; abapical spiral cord somewhat stronger, situated on distinct angulation of whorl face, forming periphery of whorls; adapical spiral cord somewhat below suture; abapical spiral cord at about one third of whorl height; spiral cords appear immediately after protoconch; teleoconch whorls ornamented with numerous straight, thread-like axial ribs; protoconch, transaxial, with axial ribs on the last part of larval shell; ribs present in subsutural position of larval shell as well as on base (circumumbilical) but fading on periphery.

Description. - Shell high-spired, slender, with straight flanks; the holotype (Fig. 23A, D, E, F) consists of the protoconch and about four teleoconch whorls, is $1.5 \mathrm{~mm}$ high and $0.75 \mathrm{~mm}$ wide; a paratype from Northern Germany (Gründel 2007a, fig. 1M-B) is $1.9 \mathrm{~mm}$ high; teleoconch whorls ornamented with two spiral cords; abapical spiral cord somewhat stronger, situated on strong angulation of whorl face; adapical spiral cord somewhat below suture; abapical spiral at about one third of whorl height; spiral cords appear immediately after protoconch (two primary spiral cords); teleoconch whorls ornamented with numerous thread-like axial ribs ( $c a 30$ per whorl); axial ribs much narrower than interspaces between them; intersections of axial ribs and spiral cords only slightly nodular; further spiral cord emerging at abapical suture; protoconch heterostrophic, transaxial, about one fourth covered by first teleoconch whorl; protoconch smooth except axial ribs on the last part of larval shell; ribs present in subsutural position of larval shell as well as on base (circumumbilical) but fading on periphery; protoconch $0.25 \mathrm{~mm}$ broad.

Remarks. - A well-preserved specimen of this species from the Toarcian/Aalenian of North Germany was illustrated by Gründel (2007a, "Promathilda sp. nov.", fig. 1M, N). It agrees well with the specimens from Mistelgau except a weakening of the axial ribs on the last preserved whorl. Our material from Mistelgau does not show this weakening of the teleoconch ornament at similar growth stages. Thus, this character is interpreted as intraspecific variation. In accordance with Gründel (2007a), it can be stated that the abapical spiral cord is situated higher in Promathildia (Teretrina) truemanni Walther, 1951 (Bajocian) and the protoconch of this species lacks axial ribs. Promathildia conoidea Gründel, 1997b (Bathonian) resembles Jurilda zapfi (see also Kaim 2004, fig. 101). However, P. conoidea is broader and has prosocline axial ribs. Promathildia concava Walther, 1951 has an entirely smooth protoconch (Kaim 2004, fig. 102). Promathilda sp. sensu Kaim (2004, fig. 106) from the Bathonian of Poland is very similar. However, the upper spire is in a somewhat more abapical position and the protoconch has a much wider diameter $(0.46 \mathrm{~mm})$.

Occurrence. - Early Aalenian and late Toarcian.

\section{Franconicilda gen. nov.}

Type species. - Franconicilda juliae sp. nov.

Etymology. - After the region Franconia in South Germany.

Diagnosis. - High spired, slender mathildoid with three spiral furrows and weak opisthocyrt axial ribs (strengthened growth lines); teleoconch whorls convex; protoconch heterostrophic, transaxial, smooth.

Remarks. - Franconicilda differs from typical mathildoid genera such as Mathilda, Tricarilda and Promathildia in having spiral furrows instead of spiral cords. It differs from the gordenellid Turritelloidea in having furrows alternating with broad bands from the beginning of the teleoconch onward.

Other species. - Only the type species is included.

Occurrence. - Late Toarcian. 


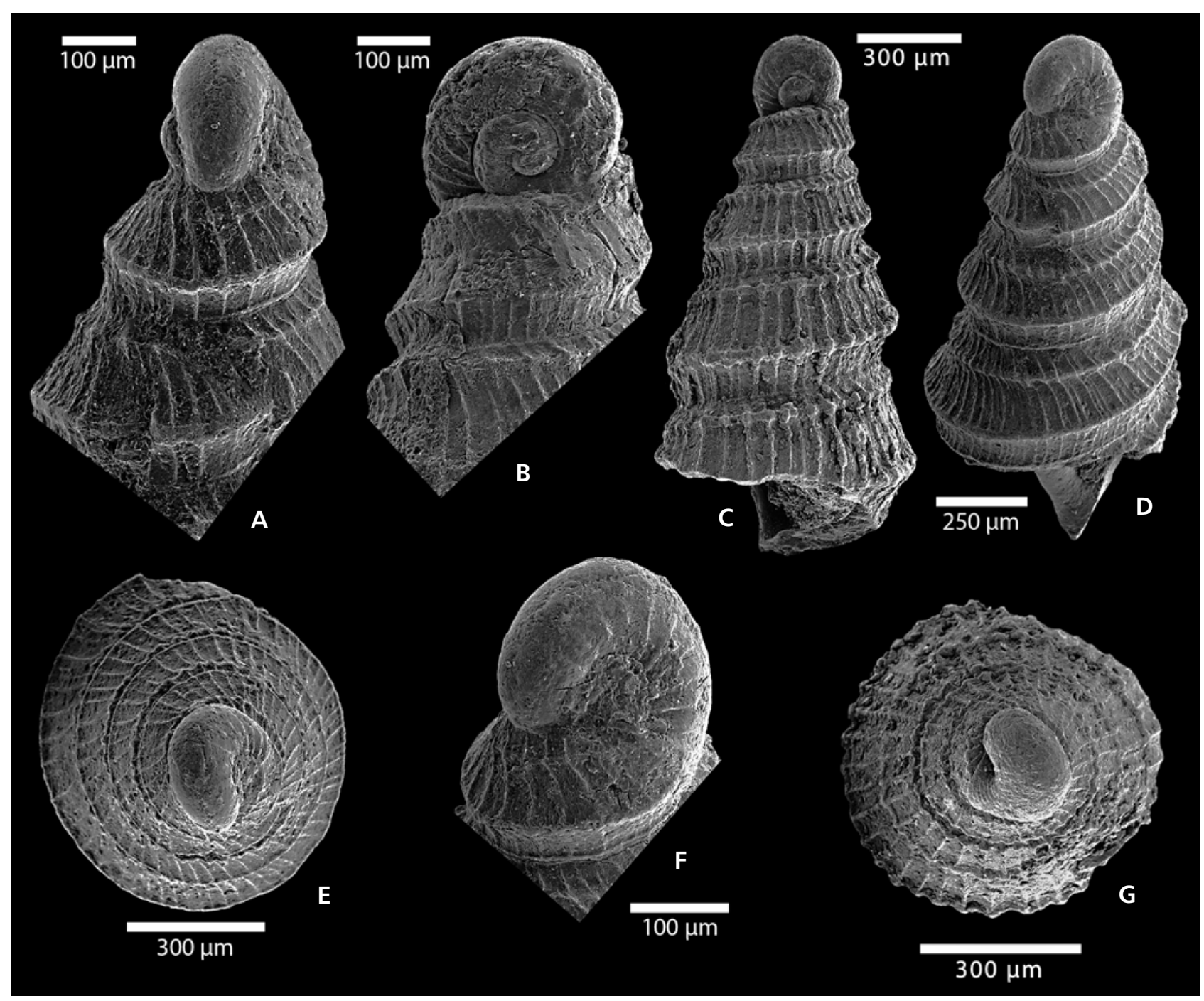

Figure 23. A, D, E, F - Jurilda zapfi Schulbert, Nützel \& Gründel sp. nov., holotype, BSPG 2011 XLII 121, $310 \mathrm{~cm}$ below Lytoceras bed. • B - Jurilda zapfi Schulbert, Nützel \& Gründel sp. nov., paratype, BSPG 2011 XLII 63, 320 below Lytoceras bed. • C, G - Jurilda zapfi Schulbert, Nützel \& Gründel sp. nov., paratype, BSPG 2011 XLII 212, 6 m above Lytoceras bed.

\section{Franconicilda juliae sp. nov.}

Figure 24A-E

Types. - Holotype BSPG 2011 XLII 84, $420 \mathrm{~cm}$ below Lytoceras bed, Fig. 24A; 2 paratypes: BSPG 2011 XLII 83, $420 \mathrm{~cm}$ below Lytoceras bed, Fig. 24B, C; BSPG 2011 XLII 132, $220 \mathrm{~cm}$ below Lytoceras bed, Fig. 24D, E.

Type horizon and locality. - Late Toarcian/early Aalenian, Opalinuston Formation, Mistelgau clay pit, Oberfranken, Germany.

Material. - Three illustrated type specimens and two additional specimens.

Etymology. - In honour of Julia Römheld, wife of first author.
Diagnosis. - High-spired, slender mathildoid of conoidal outline; teleoconch whorls convex, suture canaliculate; whorls ornamented with three spiral furrows; adapical furrow in somewhat subsutural position, separated from abapical spiral furrows by a wide area; pair of abapical furrows well below mid-whorl; lowest spiral furrow in somewhat suprasutural position; teleoconch whorls ornamented with numerous weak, opisthocyrt axial threads having the character of strengthened growth lines; base convex with one spiral furrow close to suture; protoconch transaxial.

Description. - Shell high-spired, slender; the holotype (Fig. 24A) consists of the protoconch and three to four teleoconch whorls; it is $1.5 \mathrm{~mm}$ high and $0.7 \mathrm{~mm}$ wide; teleoconch whorls convex; suture distinct; teleoconch whorls ornamented with three spiral furrows; adapical furrow in a 


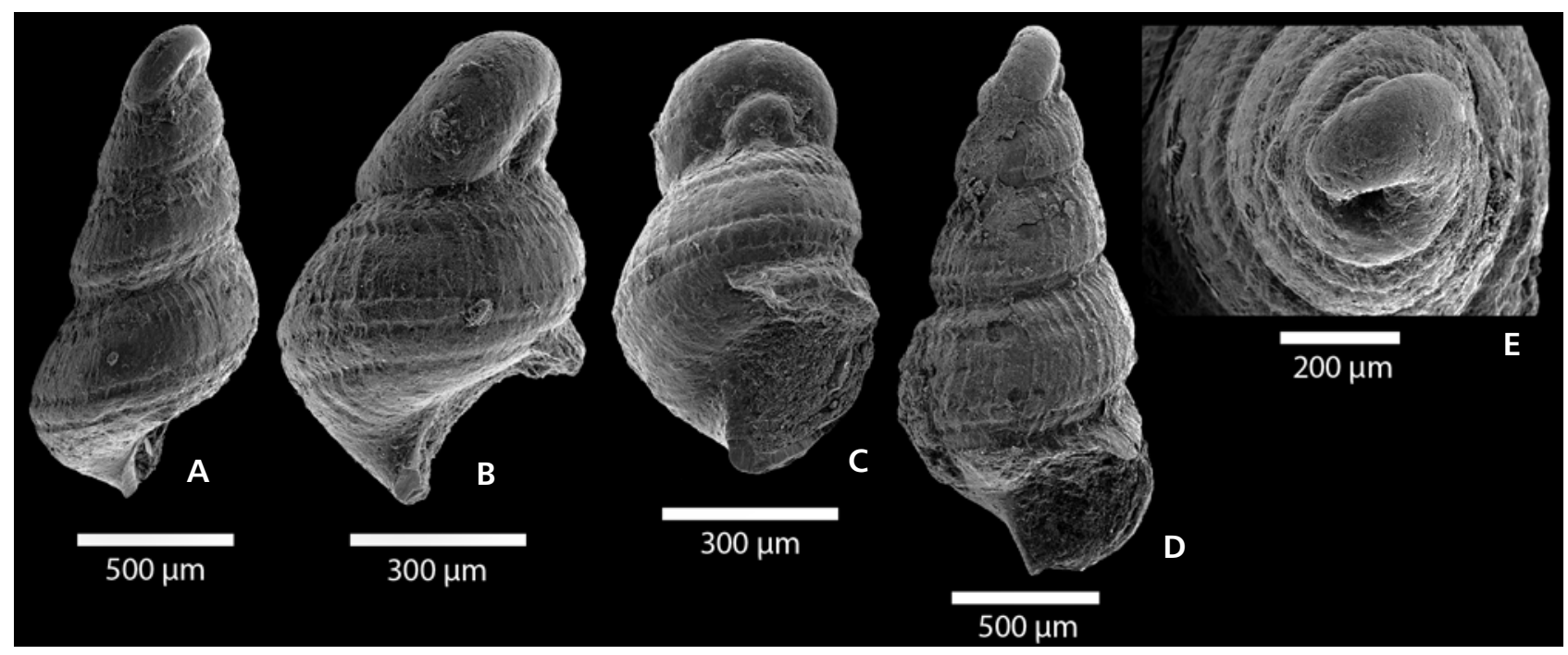

Figure 24. A - Franconicilda juliae sp. nov., holotype, BSPG 2011 XLII 84, $420 \mathrm{~cm}$ below Lytoceras bed. • B, C - Franconicilda juliae, paratype, BSPG 2011 XLII 83, $420 \mathrm{~cm}$ below Lytoceras bed. • D, E - Franconicilda juliae, paratype, BSPG 2011 XLII 132, $220 \mathrm{~cm}$ below Lytoceras bed.

somewhat subsutural position, very distant from abapical spiral furrows; pair of abapical furrows well below mid-whorl; lowest spiral furrow in a somewhat suprasutural position; teleoconch whorls ornamented with numerous weak, opisthocyrt axial threads having the character of strengthened growth lines; base convex with one spiral furrow close to suture; protoconch heterostrophic, transaxial, about one third covered by first teleoconch whorl; protoconch smooth, $0.3 \mathrm{~mm}$ wide.

Remarks. - Franconicilda juliae is unique among mathildoids in having spiral furrows as teleoconch ornament. This ornament resembles that of mature teleoconch whorls in Turritelloidea opalina (see Fig. 26). However, the early whorls of this species are ornamented with spiral cords and not with furrows (Fig. 26A).

Occurrence. - Late Toarcian.

\section{Genus Carinathilda Gründel, 1997b}

Type species. - Carinathilda carinata Gründel, 1997b, Middle Jurassic, NW Poland.

\section{Carinathilda? dieneri sp. nov.}

Figure 25A-E

Types. - Two specimens from $6 \mathrm{~m}$ above Lytoceras bed; holotype BSPG 2011 XLII 203, Fig. 25A, D, E; 1 paratype BSPG 2011 XLII 206, Fig. 25B, C.

Type horizon and locality. - Early Aalenian, Opalinuston Formation, Mistelgau clay pit, Oberfranken, Germany.
Material. - Two type specimens.

Etymology. - In honour of Walter Diener (Bayreuth), Naturwissenschaftliche Gesellschaft Bayreuth (Natural History Society Bayreuth) for his great support.

Diagnosis. - Broadly conical shell with 3 spiral cords and numerous straight, prosocline, narrow axial ribs; teleoconch whorls angulated at abapical spiral; protoconch coaxial and smooth.

Description. - Shell broadly conical; specimen illustrated in Fig. 25B, C with about three teleoconch whorls and preserved protoconch $1.6 \mathrm{~mm}$ high and $0.75 \mathrm{~mm}$ wide; whorls strongly angular at abapical spiral cord in somewhat suprasutural position; whorls ornamented with three equally spaced spiral cords which start immediately or somewhat after the protoconch; adapical spiral somewhat below suture; middle spiral cord at about mid-whorl; abapical spiral cord strongest, keel-like, forming periphery, somewhat above suture; teleoconch ornamented with numerous straight, orthocline, narrow axial ribs numbering about 30 per whorl; intersections of spiral and axial ribs only somewhat nodular; protoconch almost coaxial, seemingly smooth but strongly re-crystallized, clearly demarcated from teleoconch; protoconch diameter $0.25 \mathrm{~mm}$.

Remarks. - Carinathilda? dieneri sp. nov. is only tentatively placed in Carinathilda because it has three primary spiral cords instead of two as is typical of Carinathilda; the species represents a new genus that is described by Gründel \& Nützel (2012a, online, printed version not yet available). Carinathilda? dieneri sp. nov. resembles the 


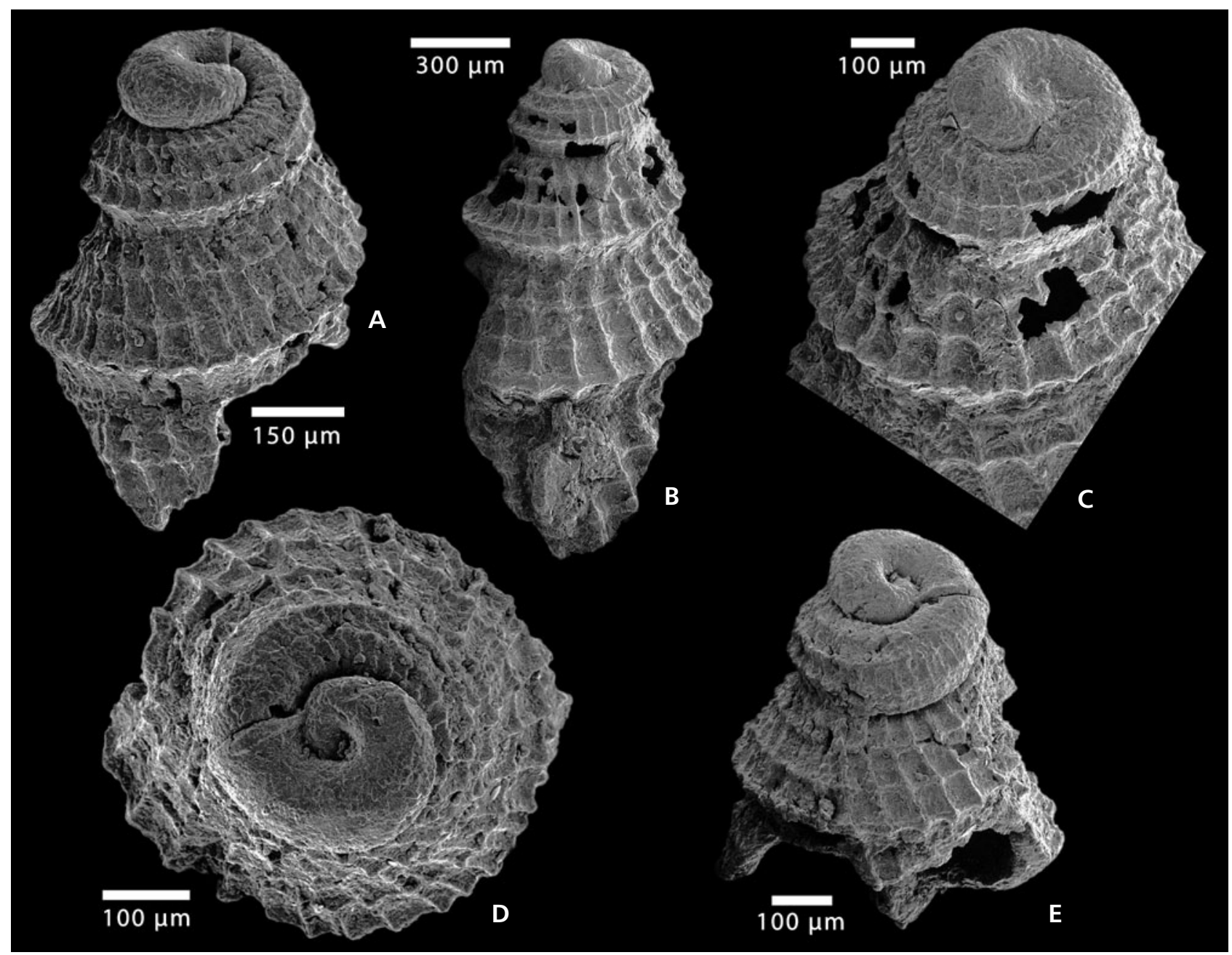

Figure 25. A, D, E-Carinathilda? dieneri sp. nov., holotype, BSPG 2011 XLII 203, 6 m above Lytoceras bed. • B, C-Carinathilda? dieneri, paratype BSPG 2011 XLII 206, $6 \mathrm{~m}$ above Lytoceras bed.

Bathonian type species of Carinathilda, C. carinata Gründel 1997b, in having an almost coaxial protoconch and a strongly carinated, broadly conical teleoconch. However, $C$. carinata has a much finer teleoconch ornament and its angulation is much higher on the whorls. Moreover, the type species of Carinathilda has a very fine micro-ornament which cannot be found in Carinathilda? dieneri sp. nov. from Mistelgau. However, the present material is strongly re-crystallized so that it is impossible to verify presence or absence of a micro-ornament. Carinathilda? dieneri sp. nov. has three primary spiral cords whereas $C$. carinata has only two. Kaim (2004) described several Middle Jurassic to Early Cretaceous species of Carinathilda. Some of them closely resemble Carinathilda? dieneri but differ in diagnostic characters such as the position of the carination and the number of spiral cords.

Occurrence. - Early Aalenian.
Family Gordenellidae Gründel, 2000

\section{Genus Promathildia Andreae, 1887}

Type species. - Mathilda janeti Cossmann, 1885, subsequent designation (Gründel \& Nützel 2012a), Bathonian, France.

Remarks. - Gründel \& Nützel (2012a) fixed Mathilda janeti Cossmann, 1885 as type species of Promathildia and considered Clathrobaculus Cossmann, 1912 to represent a junior synonym of Promathildia. These authors included Promathildia in Gordenellidae.

\section{Promathildia krumbecki (Kuhn, 1935)}

Figure 22A-D

1935 Promathildia krumbecki sp. nov. - Kuhn, p. 146, pl. 9, fig. 2a, b. 
2007a Tricarilda krumbecki. - Gründel, p. 243, fig. 4L, M.

Material. - One specimen; BSPG 2011 XLII 214, $600 \mathrm{~cm}$ above Lytoceras bed, Fig. 22A-D.

Description. - Shell high-spired, slender; specimen on Fig. 22A-D is $0.9 \mathrm{~mm}$ high and $0.38 \mathrm{~mm}$ wide; shell comprises protoconch and 2.5 teleoconch whorls; teleoconch whorls strongly convex and submedially bicarinate; carinae subdivide whorl surface into three concave belts; suture distinct; teleoconch whorls with three primary spiral cords; adapical spiral cord close to suture relatively weak; next two primary spiral cords strengthened as keels at and somewhat below mid-whorl; fourth spiral cord emerging at abapical suture, relatively weak; teleoconch whorls with opisthocyrt narrow, sharp axial ribs, about 30 per whorl, forming small nodules with intersecting spiral cords; base convex, exhibiting at least one spiral cord; protoconch almost planispiral, transaxial, umbilicated; protoconch diameter $0.23 \mathrm{~mm}$; protoconch almost entirely elevated; only lowermost part of protoconch whorl in contact with first teleoconch whorl; protoconch comprises about 2 smooth whorls; distinct ledge as demarcation to teleoconch whorls.

Remarks. - Gründel (2007a, fig. 4L, M) illustrated a micrograph of Kuhn's (1935, pl. 9, fig. 2a, b) holotype. The present specimen agrees well with the holotype. However, the protoconch of the holotype has faint ribs that are absent in our specimen maybe due to preservation. The highly elevated protoconch is typical for gordenellids e.g., of the gordenellid genus Promathildia Andreae, 1887 (Gründel \& Nützel 2012a).

Occurrence. - Early Aalenian.

\section{Genus Turritelloidea Walther, 1951}

Type species. - Turritella opalina Quenstedt, 1852, original designation, Toarcian to Aalenian, South Germany.

\section{Turritelloidea opalina (Quenstedt, 1858)}

Figure 26A-D

*1852 Turritella opalini sp. nov.; Quenstedt, p. 417, pl. 33, fig. 30.

1909 Turritella opalina. - Brösamlen, p. 275, pl. 20, fig. 44, pl. 21, fig. 1 (see here for prior synonymy).

1935 Turritella opalina. - Kuhn, p. 142, pl. 10, fig. 26.

non 1951 Promathildia (Turritelloidea) opalina. - Walther, p. 72 , pl. 3, fig. 17 , pl. 5 , fig. 10.10 .

non 1995 Turrithilda opalina. - Schröder, p. 49, pl. 7, figs $13-15$, pl. 15 , fig. 7 . 2005a Turritelloidea opalina. - Gründel, p. 326, figs 1-3.

2012a Turritelloidea opalina. - Gründel \& Nützel, p. 23, fig. $6 \mathrm{C}$.

For more synonymy see Gründel (2005a).

Material. - Five specimens; $150 \mathrm{~cm}$, Naturkundemuseum Coburg, NMC 20387; Urwelt-Museum Oberfranken, Bayreuth, Eggmaier collection.

Description. - The specimen illustrated on Fig. 26A-D (also illustrated by Gründel 2005a, figs 1-3) from Mistelgau is much better preserved than Quenstedt's holotype (1852, p. 417, pl. 33, fig. 30; Gründel 2005a, fig. 1/1-3). Shell high-spired, slender with 17 preserved whorls; protoconch missing; height $4.2 \mathrm{~cm}$, width $1 \mathrm{~cm}$; whorl face convex with impressed suture; early teleoconch whorls exhibit four spiral cords with two more added during further ontogeny; spiral cords of early teleoconch of about equal strength and equally spaced; spiral cords becoming broader and form ribbon-like ornament on mature whorls; teleoconch with faint opisthocyrt axial threads forming a reticulate pattern with spiral cords; on mature teleoconch whorls, axial ornamentation fading out slowly; base convex, with faint spiral cords.

Remarks. - Gründel (2005a) and Gründel \& Nützel (2012a) described this shell detailed and discussed the systematic position of the genus Turritelloidea. Apart from Quenstedt's type material, Gründel (2005a) had material from Mistelgau at hand, including a specimen with preserved coaxial protoconch. Turritelloidea opalina is one of the largest gastropods from Mistelgau; it is very rare.

Occurrence. - Late Toarcian and early Aalenian.

\section{Genus Proacirsa Cossmann, 1912}

Type species. - Turritella inornata Terquem \& Jourdy, 1871, Bathonian, France.

\section{Proacirsa nuda (zu Münster in Goldfuss, 1844)} Figure 26E

1844 Turritella nuda; zu Münster in Goldfuss, p. 106, pl. 196, fig. 13.

1935 Turritella nuda - Kuhn, p. 141, pl. 10, fig. 12.

Material. - One specimen from Mistelgau, UrweltMuseum Oberfranken, Bayreuth, Eggmaier collection.

Description. - Slender, high-spired shell; illustrated specimen (Fig. 26E) $52.4 \mathrm{~mm}$ high and $13.4 \mathrm{~mm}$ wide; shell comprises 12 teleoconch whorls; whorls distinctly convex 


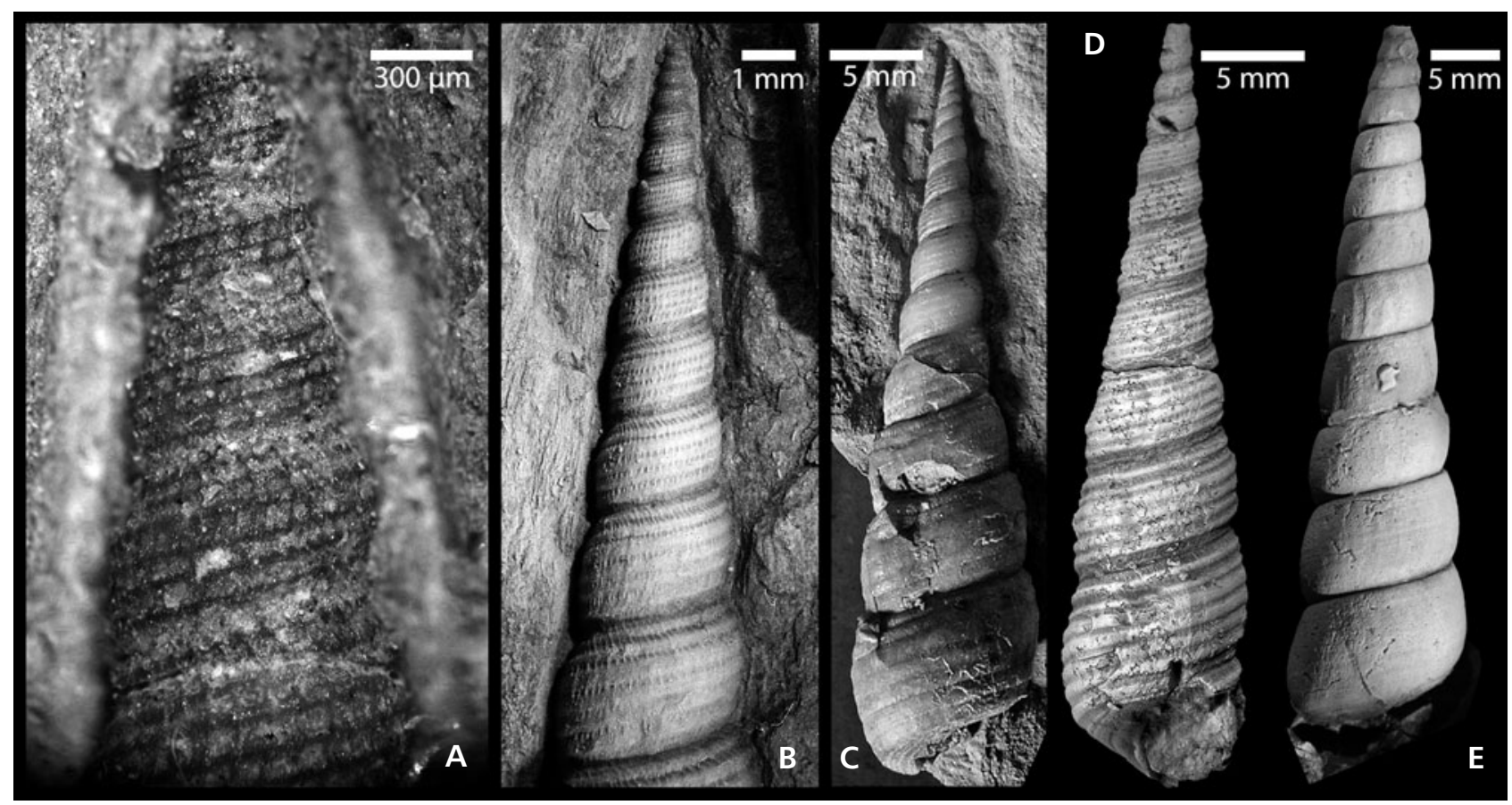

Figure 26. A-C - Turritelloidea opalina (Quenstedt, 1858), Mistelgau, $150 \mathrm{~cm}$ below Lytoceras bed, Naturkundemuseum Coburg, NMC 20387. -D - Urwelt-Museum Oberfranken, Bayreuth, Eggmaier collection. • E - Proacirsa nuda (zu Münster in Goldfuss, 1844), Urwelt-Museum Oberfranken, Bayreuth, Eggmaier collection.

exhibiting faint spirals on later whorls; growth lines opisthocyrt; suture impressed; apex missing; base with faint spiral ornament.

Remarks. - This is the only specimen at hand. Because of heavy blast cleaning, the ornament is obscured. The protoconch and first teleoconch whorl are not preserved.

Occurrence. - Early Aalenian.

Family Tofanellidae Bandel, 1995

\section{Genus Conusella Gründel, 1999b}

Type species. - Conusella conica Gründel, 1999b, late Pliensbachian, Northeast Germany.

\section{Conusella convexa sp. nov.}

Figure 27D, E

Types. - Holotype BSPG 2011 XLII 179, 20-40 cm, Fig. 27D, E.

Type horizon and locality. - Early Aalenian, Opalinuston Formation, Mistelgau clay pit, Oberfranken, Germany.

Material. - Only the holotype.
Etymology. - Latin, because of the convex teleoconch whorls.

Diagnosis. - Conusella species with distinctly convex teleoconch whorls; whorls relatively low; initial teleoconch whorl broader than protoconch; growth lines distinctly prosocyrt.

Description. - Shell high-spired; illustrated specimen (Fig. 27D, E) is $1.7 \mathrm{~mm}$ high and $0.85 \mathrm{~mm}$ wide; shell comprises about 5 relatively low whorls; impressed suture with narrow shoulder; whorls distinctly convex; growth lines prosocyrt; base convex; transition of whorl face to base evenly rounded; protoconch heterostrophic, coaxial (tofanellid), smooth; transition between protoconch and teleoconch indistinct due to preservation.

Remarks. - Conusella convexa sp. nov. has much more convex whorls than the other three described species of this genus: Conusella conica Gründel, 1999b (Pliensbachian), Conusella? pacifica Bandel, Gründel \& Maxwell, 2000 (late Early to early Middle Jurassic, New Zealand) and Conusella torusa Gründel, 2006 (late Bathonian). It has also much more convex whorls than Conusella sp. as reported by Gründel \& Kaim (2006) from the late Oxfordian of Poland. It differs from Usedomella species in being broader and having stouter whorls. Morever, the protoconch of Usedomella is broader than the initial teleoconch whorls. 


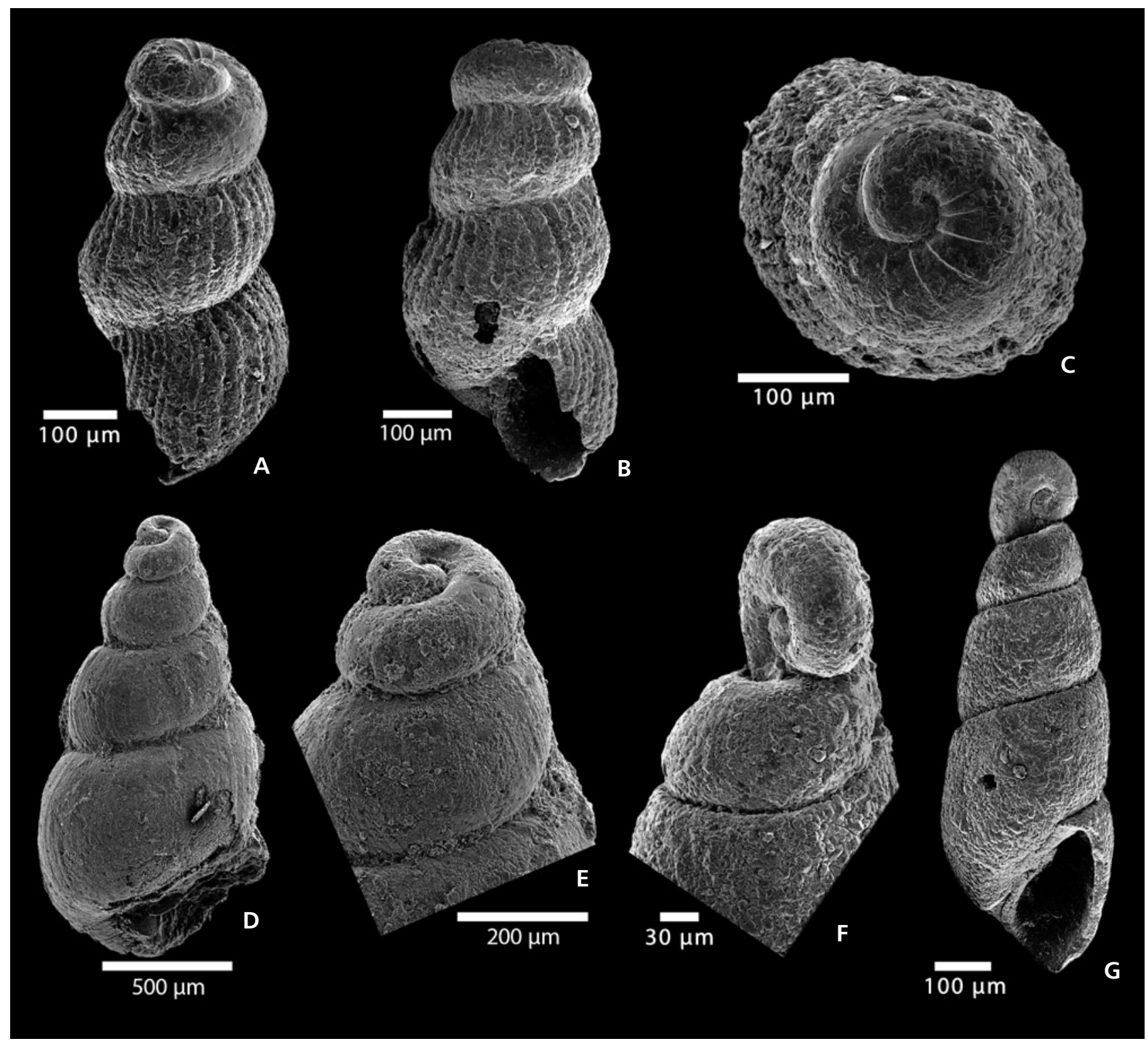

Figure 27. A-C-Graphis weissi (Gründel, 1999d), BSPG 2011 XLII 213, $6 \mathrm{~m}$ above Lytoceras bed. • D, E-Conusella convexa sp. nov., holotype, BSPG XLII 179, 20-40 cm below Lytoceras bed. • F, G - Falsoebala urdatica Gründel, Nützel \& Schulbert, BSPG 2011 XLII 204, $6 \mathrm{~m}$ above Lytoceras bed.

Occurrence. - Early Aalenian.

\section{Genus Graphis Jeffreys, 1867}

Type species. - Turbo unicus Montagu, 1803 (= junior subjective synonym of Turbo albidus Kanmacher, 1798), original designation, Recent, North Atlantic and Mediterranean.

\section{Graphis weissi (Gründel, 1999d)}

Figure 27A-C

1999d Rotfanella weissi sp. nov.; Gründel, p. 294, pl. 2, figs $4-8$.
Material. - One specimen, BSPG 2011 XLII 213, $600 \mathrm{~cm}$ above Lytoceras bed, Fig. 27A-C.

Description. - Shell high-spired; illustrated specimen (Fig. 27A-C) with protoconch and two preserved teleoconch whorls $0.6 \mathrm{~mm}$ high and $0.3 \mathrm{~mm}$ wide; whorls distinctly convex with about 30 sigmoidal ribs; suture deep; base convex with continuous ribs; protoconch heterostrophic, coaxial; protoconch width and height $0.2 \mathrm{~mm}$; protoconch shows strong opisthocyrt subsutural ribs which fade on whorl face and toward transition to teleoconch.

Remarks. - The illustrated specimen from Mistelgau does not show spiral ornamentation on the teleoconch that was 
reported for the type material from the Aalenian of Kremmelsdorf (near Bamberg) (Gründel 1999d, pl. 2, figs 4-8). This lack might be due to preservation. The present specimen differs from G. sinecosta Gründel 2007a (early Aalenian) in having ribs on the protoconch.

Occurrence. - Early Aalenian.

Superfamily Pyramidelloidea Gray, 1840a

Family Murchisonellidae Casey, 1904

Remarks. - Bouchet et al. (2005) considered Ebalidae to represent a junior synonym of Murchisonellidae Casey, 1904 which is assigned to Pyramidelloidea.

\section{Genus Falsoebala Gründel, 1998b}

Type species. - Falsoebala compacta Gründel, 1998b, Callovian, NW Poland and NE Germany.

\section{Falsoebala urdatica Gründel, Nützel \& Schulbert in Gründel, 2007a \\ Figure $27 \mathrm{~F}-\mathrm{G}$}

*2007a Falsoebala urdatica Gründel, Nützel \& Schulbert sp. nov.; Gründel, p. 246, figs 2M-P.

Material. - One specimen, BSPG 2011 XLII 204, 6 m above Lytoceras bed, Fig. 27F, G.

Description. - Slender, high-spired shell; illustrated specimen (Fig. 27F) is $0.92 \mathrm{~mm}$ high and $0.31 \mathrm{~mm}$ wide; teleoconch comprises about 3.5 unornamented whorls; whorl flanks slightly convex; suture distinct; base rounded, not demarcated from whorl face; no ramp developed; aperture oval, not fully preserved, slightly tapering adapically and rounded in its abapical portion; protoconch smooth, nearly transaxial, elevated, consisting of about two almost planispiral, flatly sinistral whorls; diameter of protoconch $0.16 \mathrm{~mm}$.

Remarks. - Gründel, Nützel \& Schulbert in Gründel (2007a) based this species on better preserved material from Marnitz/Northern Germany. They also discussed the relationships to similar Jurassic species.

Occurrence. - Early Aalenian.

\section{Hummelgauia gen. nov.}

Type species. - Hummelgauia microstriata sp. nov.
Etymology. - After the Hummelgau district in which Mistelgau is situated.

Diagnosis. - High-spired shell with fine spiral threads covering the entire whorl face of mature teleoconch whorls; teleoconch whorls convex; protoconch smooth, medioaxial with spire covered by first teleoconch whorl.

Remarks. - Donaldina Knight, 1933 and Neodonaldina Bandel, 1994 have a more pronounced teleoconch ornament and a coaxial protoconch. Unfortunately, the growth line pattern of Hummelgauia could not be observed due to preservation. The similar modern genus Murchisonella Mörch, 1875 is characterized by a distinct sinuosity in the outer lip. At least the better known representatives have a more or less extensive subsutural zone lacking spiral striation on all teleoconch whorls (Warén 1994, Bandel 2005) and some have angulated whorls. By contrast, the whorl face of the mature teleoconch of Hummelgauia is entirely covered by fine spiral threads and the whorls are evenly rounded. Moreover, the protoconch of Murchisonella is much more elevated than that of Hummelgauia.

Other species. - Only the type species is included.

Occurrence. - Early Aalenian.

Hummelgauia microstriata sp. nov. Figure 28A-F

Types. - Holotype BSPG 2011 XLII 150, $150 \mathrm{~cm}$ below Lytoceras bed, Fig. 28A, B, F; paratype BSPG 2011 XLII 80, $130 \mathrm{~cm}$ below Lytoceras bed.

Type horizon and locality. - Early Aalenian, Opalinuston Formation, Mistelgau clay pit, Oberfranken, Germany.

Material. - 2 type specimens.

Etymology. - Latin, because of the fine spiral cords.

Diagnosis. - As for monotypic genus.

Description. - Shell high-spired, slender; holotype (Fig. 28A, B, F) is $2.5 \mathrm{~mm}$ high and $0.8 \mathrm{~mm}$ broad; teleoconch comprises 8 whorls; whorls convex; suture distinct; 6 faint spiral threads visible on abapical part of first teleoconch whorl; adapical part of first teleoconch whorl seems to be smooth; spiral threads also present on apical part of later teleoconch so that 12 spiral threads are present on third and later teleoconch whorls; ornament does not fade on later whorls, but density of spiral threads increases; no further ornamentation visible; base slightly convex; protoconch 


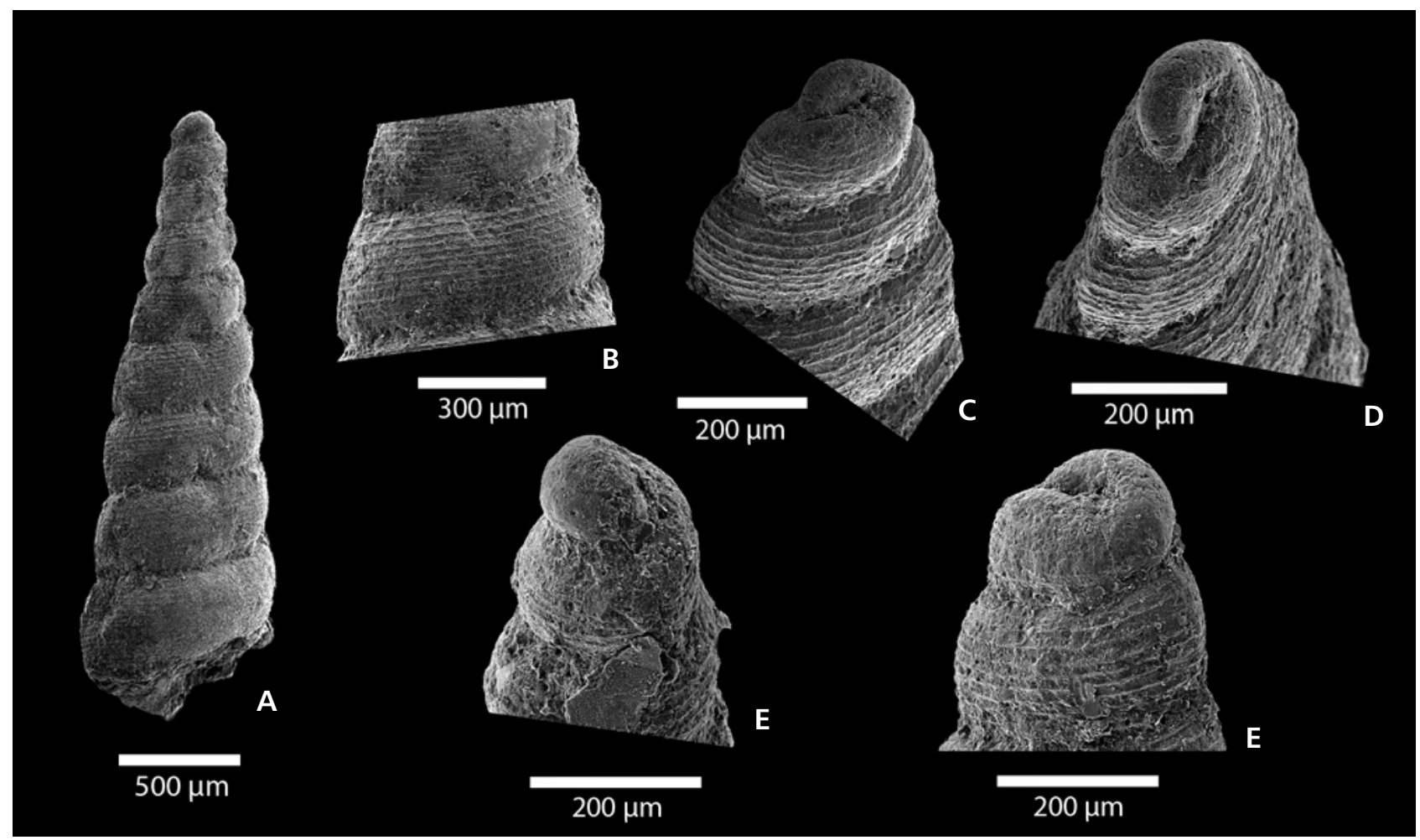

Figure 28. A, B, E - Hummelgauia microstriata sp. nov., holotype, BSPG 2011 XLII 150, $150 \mathrm{~cm}$ below Lytoceras bed. • C, D, F - Hummelgauia microstriata, paratype, BSPG 2011 XLII 80,130 cm below Lytoceras bed.

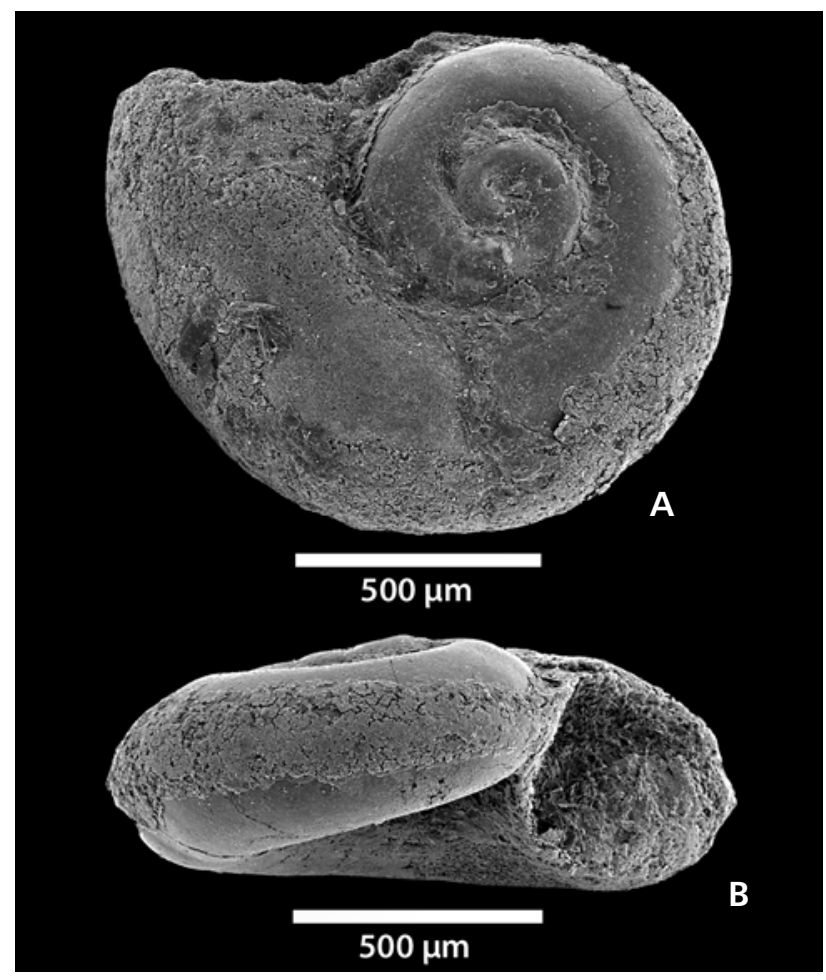

Figure 29. A, B - ?Bandellina sp., BSPG 2011 XLII 130, $290 \mathrm{~cm}$ below Lytoceras bed. heterostrophic, medioaxial and smooth; protoconch height of holotype is $0.18 \mathrm{~mm}$ and width $0.13 \mathrm{~mm}$; protoconch consists of about 1.5 to 2 whorls; first protoconch whorl completely covered by first teleoconch whorl; demarcation between protoconch and teleoconch sharp and distinct.

Occurrence. - Early Aalenian.

Superfamily Valvatoidea Gray, 1840b

Family Cornirostridae Ponder, 1990

\section{Genus Bandellina Schröder, 1995}

Type species. - Bandellina laevissima Schröder, 1995, Early Cretaceous, Poland.

\section{Bandellina? sp.}

Figure 29A, B

Material. - Two specimens; BSPG 2011 XLII 130, 290 cm, Fig. 29A, B; BSPG 2011 XLII 182, $460 \mathrm{~cm}$.

Description. - Low-spired, nearly planispiral shell with about three whorls, $1.3 \mathrm{~mm}$ wide, $0.5 \mathrm{~mm}$ high; teleoconch 
whorls ( $c a 1.3$ whorls) round, with slight rounded edge on the apical top; no ornamentation or growth lines visible; base phaneromphalous, rounded; aperture not preserved; small and smooth heterostrophic coaxial protoconch; illustrated specimen (Fig. 29A, B) shows weakly thickened rib at transition to teleoconch.

Remarks. - There are some Mesozoic heterostrophic gastropod genera exhibiting a largely smooth shell and being more or less planispiral or very low-spired. Kaim (2004) considered such genera as synonyms of Bandellina Schröder (1995): Alexogyra Bandel, 1996 from the Cassian Formation (Late Triassic) in which teleoconch whorls seem to increase faster than in the present material; Carbonina Bandel, 1996 from the Cassian Formation and Doggerostra Gründel, 1998b from the Middle Jurassic which has a more or less turbiniform teleoconch shape. The present material from Mistelgau is not very well preserved and thus, we cannot assign it to the genus Bandellina with certainty.

Occurrence. - Late Toarcian.

Order Architectibranchia Haszprunar, 1985

Family Tubiferidae Cossmann, 1895a

\section{Genus Cossmannina Gründel \& Nützel, 2012b}

Type species. - Actaeonina (Ovactaeonina) abdominiformis Schröder, 1995, Pliensbachian, North Germany.

\section{Cossmannina eggmaieri sp. nov.}

Figure 30A-J

Types. - Holotype BSPG 2011 XLII 10, Fig. 30D-G; paratypes: BSPG 2011 XLII 197, $510 \mathrm{~cm}$; BSPG 2011 XLII 198, $510 \mathrm{~cm}$; BSPG 2011 XLII 11-13, $5 \mathrm{~m}$ above Lytoceras bed (Aalenian); BSPG 2011 XLII 66, $320 \mathrm{~cm}$ below Lytoceras bed (Toarcian), Fig. 30C, H; BSPG 2011 XLII 98, $530 \mathrm{~cm}$; BSPG 2011 XLII 106, $320 \mathrm{~cm}$; BSPG 2011 XLII 160, 500 cm, Fig. 30A; BSPG 2011 XLII 168, $110 \mathrm{~cm}$ Fig. 30B, I, J; BSPG 2011 XLII 184, $460 \mathrm{~cm}$.

Type horizon and locality. - Late Toarcian/early Aalenian, Opalinuston Formation, Mistelgau clay pit near Mistelgau, Oberfranken, Germany.

Material. - 10 type specimens, 4 additional specimens, BSPG 2011 XLII 186, 460 cm; BSPG 2011XLII 197, 198, $510 \mathrm{~cm}$, numerous additional specimens.

Etymology. - In honour of Stefan Eggmaier, UrweltMuseum Oberfranken, Bayreuth who collected specimens for this study.
Diagnosis. - Cossmannina species with slightly convex whorls and a narrow shoulder but without distinct ramp; protoconch trans- to slightly medio-axial; base of larval shell umbilicated and bearing a ledge.

Description. - Shell egg shaped; protoconch heterostrophic, trans- to slightly medio-axial, $0.32 \mathrm{~mm}$ wide, smooth; apex and spire of protoconch completely covered by first teleoconch whorl; base of larval whorls minutely phaneromphalous with a ledge on the last part of the larval shell near the umbilicus; whorl face of teleoconch slightly convex with periphery low on the whorl, visible only on last whorl, otherwise covered by following whorl; narrow, rounded shoulder sometimes with very faint subsutural depression (Fig. 30C); suture distinct; early teleoconch with prosocyrt to sinuate growth-lines which are later obscured by preservation; first teleoconch whorl exhibits faint subsutural opisthocline growth-lines which fade on abapical whorl face (Fig. 30D, E); teleoconch largely smooth, seemingly with faint spiral striae (Fig. 30I); aperture not well preserved, seemingly higher than wide, probably teardrop shaped; base strongly convex; transition from whorl face to base evenly rounded.

Remarks. - The narrow shoulder is unusual for the genus Cossmannina. On the other hand it is distinct from a true ramp as present in Tubifer or Sinuarbullina. The ledge on the base of the larval whorls is to our knowledge unique in Cossmannina and related genera. Cossmannina eggmaieri is one of the most abundant species in the Mistelgau clay pit and is especially frequent in samples of Aalenian age.

Occurrence. - Late Toarcian and early Aalenian.

\section{Genus Costactaeon Gründel, 1997c}

Type species. - Costactaeon schroederi Gründel, 1997c, early Aalenian, North Germany.

\section{Costactaeon schroederi Gründel, 1997c}

Figure 31A-I

part 1951 Actaeonina (Cylindrobullina) variablis (Brauns). Walther, p. 91 (non pl. 5, fig. 3a-b).

1997c Costactaeon schroederi sp. nov.; Gründel, p. 183, pl. 3, figs 4-7.

2007a Costactaeon schroederi. - Gründel, p. 249, fig. 3n.

Material. - 64 specimens; BSPG 2011 XLII 180, 20-40 cm below Lytoceras bed, Fig. 31A; BSPG 2011 XLII 20, 5 m above Lytoceras bed; BSPG 2011 XLII $81,130 \mathrm{~cm}$ below 


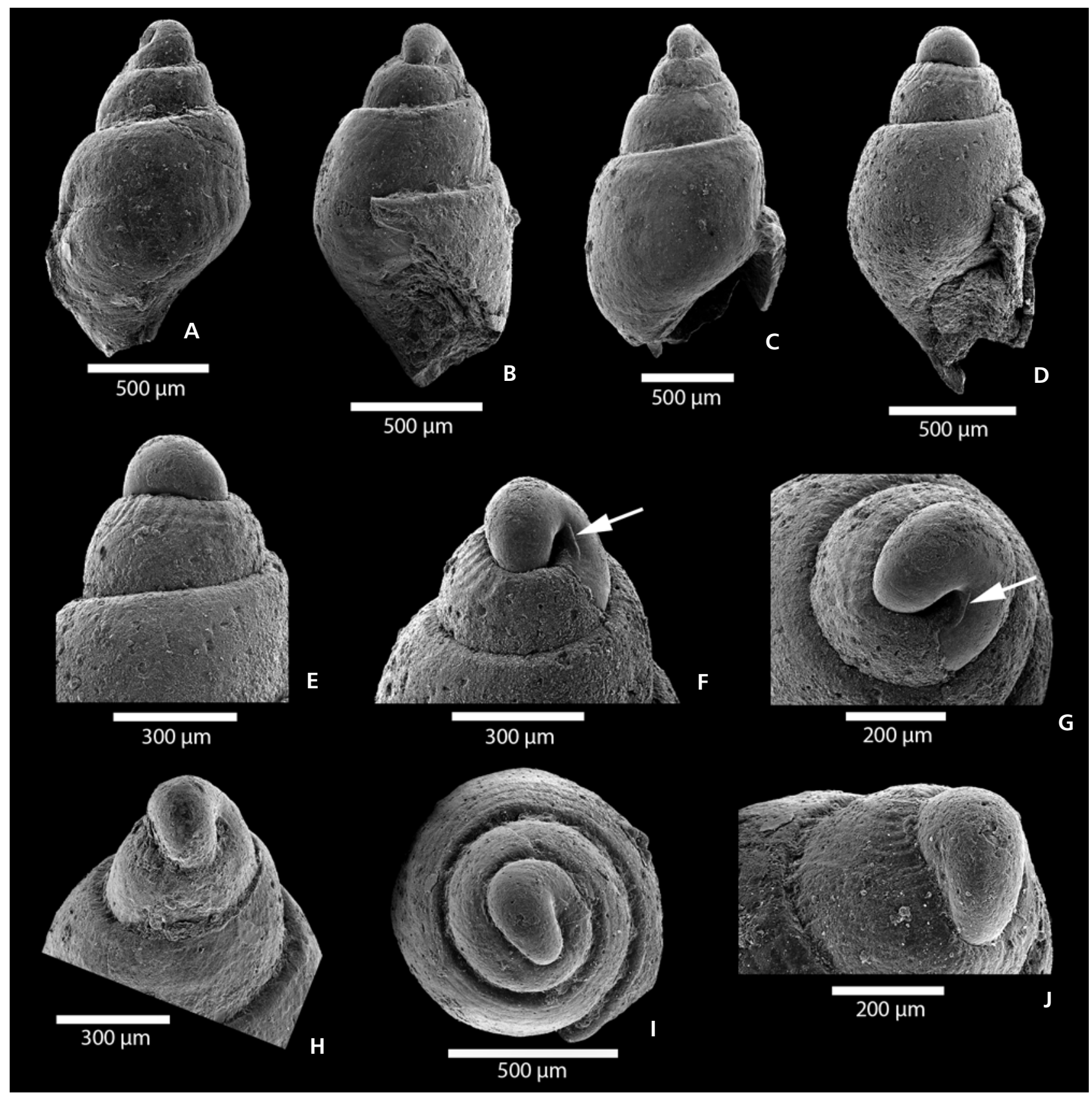

Figure 30. Cossmannina eggmaieri sp. nov. • A - paratype BSPG 2011 XLII 160, $500 \mathrm{~cm}$ below Lytoceras bed. • B, I, J - paratype BSPG 2011 XLII $168,110 \mathrm{~cm}$ below Lytoceras bed. $\cdot \mathrm{D}-\mathrm{G}$ - holotype, BSPG 2011 XLII 10, $5 \mathrm{~m}$ above Lytoceras bed, white arrows show edge on the last part of the larval shell near the umbilicus. • C, H - paratype, BSPG 2011 XLII 66, $320 \mathrm{~cm}$ below Lytoceras bed.

Lytoceras bed; BSPG 2011 XLII 90, 40-60 cm below Lytoceras bed; BSPG 2011 XLII 176, $300 \mathrm{~cm}$ below Lytoceras bed, Fig. 31C, H; BSPG 2011 XLII 209, $600 \mathrm{~cm}$ above Lytoceras bed, Fig. 31E; BSPG 2011 XLII 210, $600 \mathrm{~cm}$ above Lytoceras bed, Fig. 31D, I; BSPG 2011 XLII 215, $600 \mathrm{~cm}$ above Lytoceras bed.

Description. - Shell fusiform to egg shaped; specimen illustrated in Fig. 31A is $1 \mathrm{~mm}$ high and $0.7 \mathrm{~mm}$ broad with two teleoconch whorls preserved; whorl face convex; ramp narrow, almost horizontal to slightly oblique producing gradate spire; weak delimiting spiral furrow abapical of edge of ramp; numerous prosocyrt collabral axial ribs which fade on adapical part of whorl; aperture not preserved but seemingly drop-shaped with rounded concave inner lip; base strongly convex; transition from whorl face to base evenly rounded; growth lines prosocyrt on base and lower part of whorl face; growth lines forming a wide 


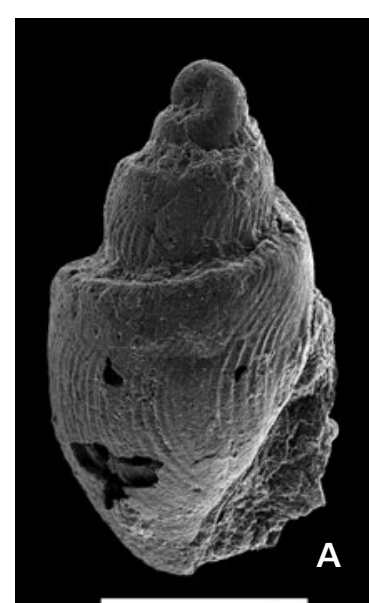

$500 \mu \mathrm{m}$

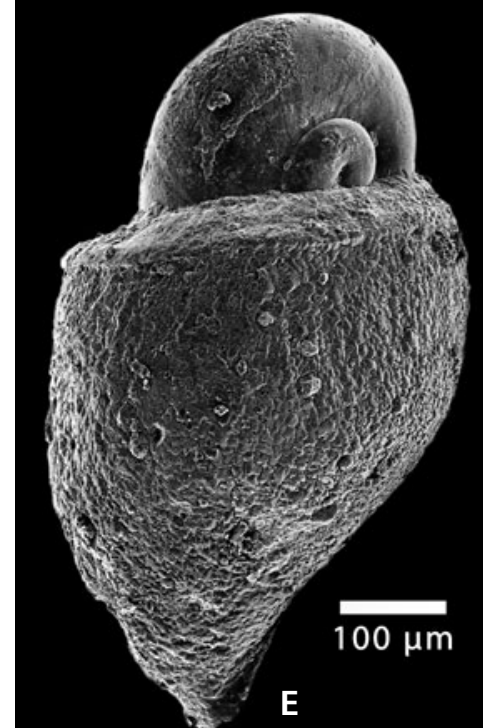

E
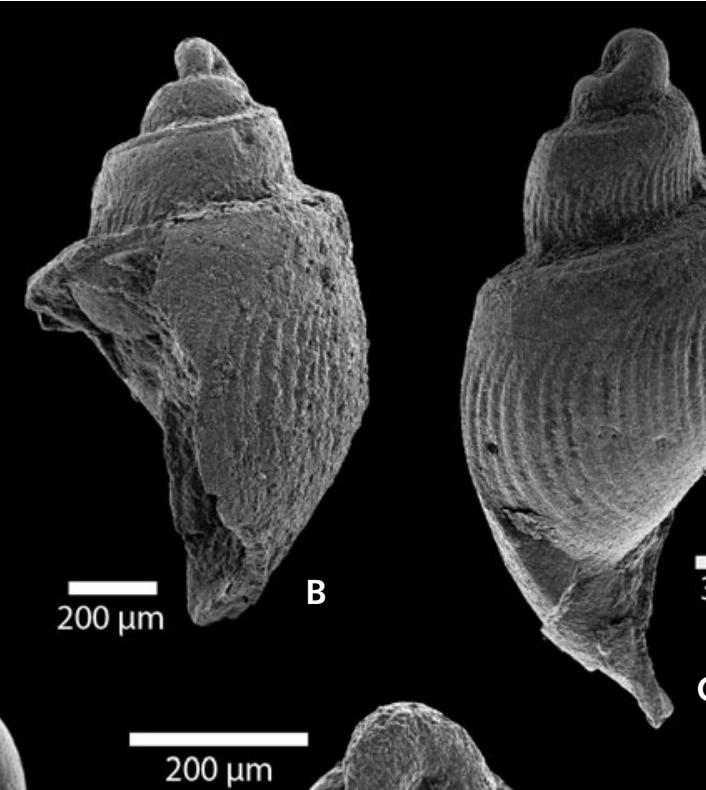
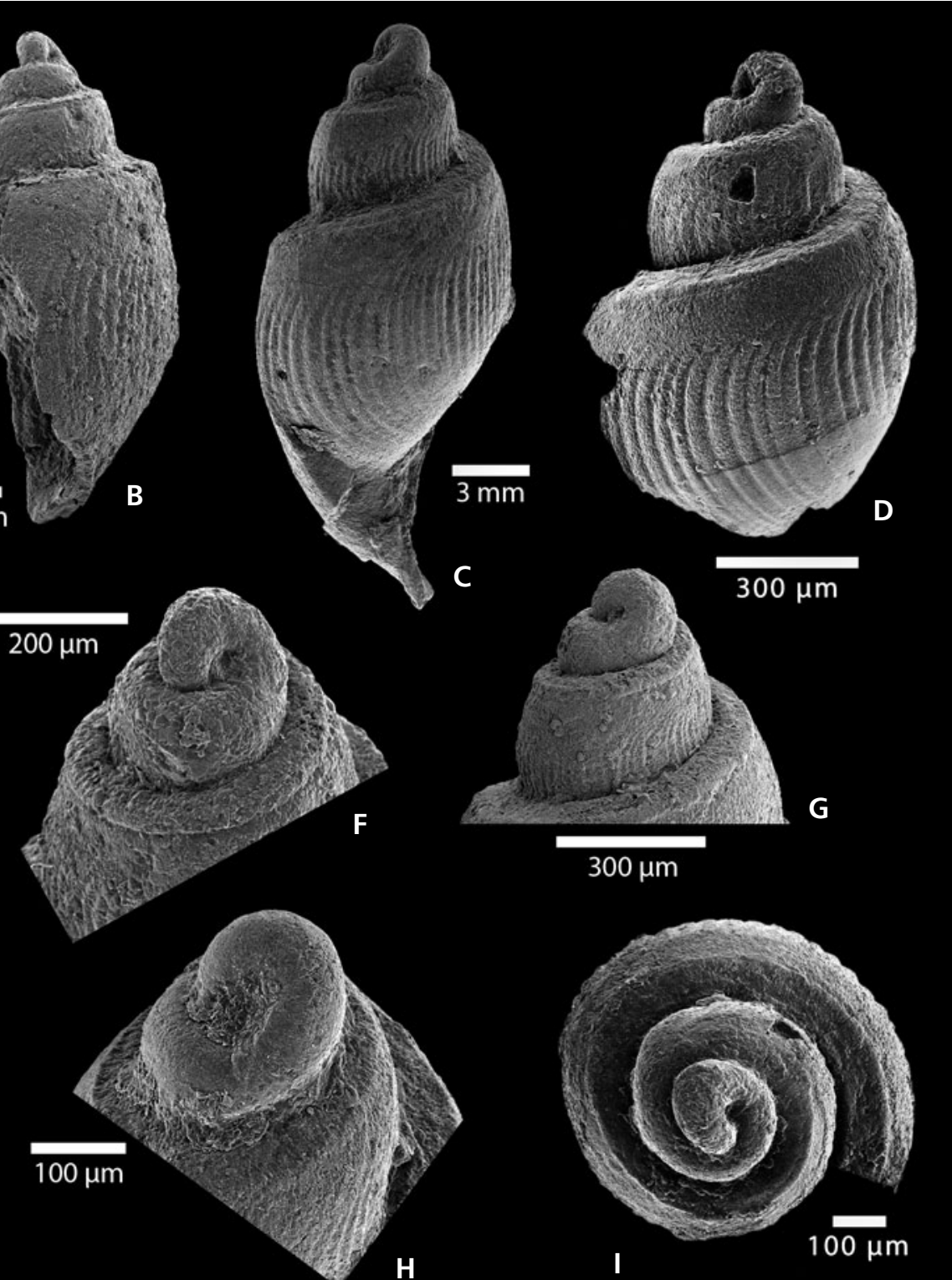

H
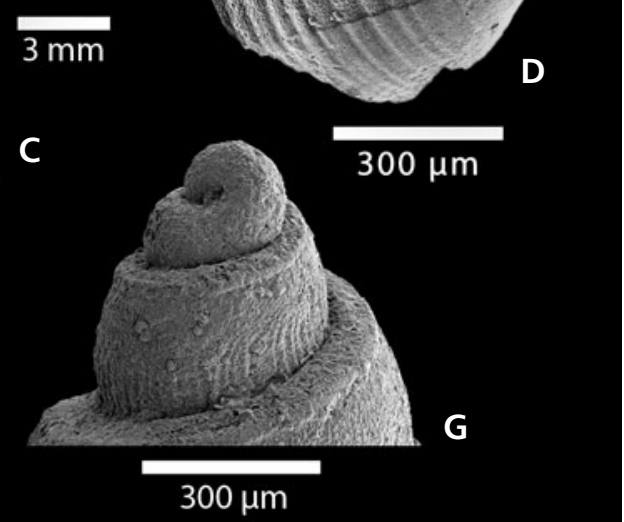
1997c, BSPG 2011 XLII 22, $5 \mathrm{~m}$ above Lytoceras bed. $\bullet$ C, H - BSPG 2011 XLII 176, $300 \mathrm{~cm}$ below Lytoceras bed. • D, I - Costactaeon schroederi, BSPG 2011 XLII 210, $6 \mathrm{~m}$ above Lytoceras bed. • E - Costactaeon schroederi, BSPG 2011 XLII 209, $6 \mathrm{~m}$ above Lytoceras bed. • F, G - BSPG 2011 XLII $20,5 \mathrm{~m}$ above Lytoceras bed.

opisthocyrt sinus on ramp and adapical part of whorl face with backmost point at edge of ramp; protoconch heterostrophic, compact trochospiral, trans- to slightly medioaxial; height and width of protoconch is $0.2 \mathrm{~mm}$; protoconch whorls smooth.

Remarks. - Gründel (1997c) described three Toarcian to Aalenian species of Costactaeon, which resemble each other closely: C. variabilis (Brauns, 1865), C. rugosa Gründel, 1997c and C. schroederi Gründel, 1997c. They may represent synonyms. Our material seems to be closest to Costactaeon schroederi that has a protoconch without ribs and a furrow below the ramp. Most of the present material from Mistelgau does not show ornamentation on the protoconchs probably due to preservation. However, the juvenile specimen illustrated in Fig. 31E displays distinct, growth line-like, opisthocline subsutural axial threads on the second protoconch whorl. Costactaeon variabilis (Brauns, 1865) has much less angulated whorls.

Occurrence. - Late Toarcian and early Aalenian. 


\section{Genus Sinuarbullina Gründel, 1997c}

Type species. - Sinuarbullina ansorgi Gründel, 1997c, Bathonian, NE Germany and NW Poland.

Remarks. - Sinuarbullina is the oldest certain genus of architectibranchs (formerly opisthobranchs) with earliest members from the Early Triassic (Nützel 2005, Nützel \& Schulbert 2005, Gründel \& Nützel 2012b). The genus is diverse in Triassic and Jurassic marine gastropod faunas worldwide.

\section{Sinuarbullina mistelgauensis Schulbert, Nützel \& Gründel sp. nov.}

Figure 32A-D

Types. - Holotype BSPG 2011 XLII 119, $310 \mathrm{~cm}$, Fig. 32B, D; 4 paratypes: BSPG 2011 XLII 88, 40-60 cm below Lytoceras bed; BSPG 2011 XLII 193, $450 \mathrm{~cm}$ below Lytoceras bed, Fig. 32A; BSPG 2011 XLII 194, $450 \mathrm{~cm}$ below Lytoceras bed, Fig. 32C; BSPG 2011 XLII 217, $600 \mathrm{~cm}$ above Lytoceras bed.

Type horizon and locality. - Late Toarcian/early Aalenian, Opalinuston Formation, Mistelgau clay pit, Oberfranken, Germany.

Material. - Five type specimens and 3 additional specimens, BSPG 2011 XLII 94, 530 below Lytoceras bed; BSPG 2011 XLII 181, $460 \mathrm{~cm}$ below Lytoceras bed; BSPG 2011 XLII 183, 460 below Lytoceras bed.

Etymology. - After the village of Mistelgau.

Diagnosis. - Relatively high-spired Sinuarbullina with narrow subsutural shoulder; spire high conical; whorl face slightly convex; without spiral furrows; protoconch elevated, nearly transaxial.

Description. - Shell relatively slender with high conical spire; illustrated specimen (Fig. 32B) consists of 3 whorls (incomplete) is $2.5 \mathrm{~mm}$ high and $1.1 \mathrm{~mm}$ wide; spire angle $33^{\circ}$; whorl face slightly convex to almost straight; suture distinct; narrow, rounded, shoulder-like subsutural ramp; whorls smooth; growth lines not well preserved but obviously strongly backward curving in subsutural zone; base convex with even transition from whorl face; aperture is not preserved; protoconch nearly transaxial, smooth, consisting of about 2 whorls, heterostrophic with a diameter of $0.35 \mathrm{~mm}$; transition to teleoconch marked by a faint prosocyrt ledge.

Remarks. - Sinuarbullina mistelgauensis is distinct in our collection although the preservation is not ideal. The placement in Sinuarbullina is suggested by the strong subsutural sinus of the growth lines. The ramp is not very distinct and has more the character of a shoulder as is also the case in the type species of Sinuarbullina (see Gründel \& Nützel 2012b).

Occurrence. - Late Toarcian and early Aalenian.

\section{Genus Striactaeonina Cossmann, 1895b}

Type species. - Orthostoma avena Terquem, 1855, Hettangian, Luxembourg.

\section{Striactaeonina waltschewi Schulbert, Nützel \& Gründel sp. nov.}

Figure 32H-J

Types. - Holotype BSPG 2011 XLII 178, $300 \mathrm{~cm}$, Fig. 32H-J.

Type horizon and locality. - Late Toarcian/early Aalenian, Opalinuston Formation, Mistelgau clay pit, Oberfranken, Germany.

Material. - Only the holotype.

Etymology. - In honour of Anton Waltschew for his contribution to the knowledge of the Jurassic of Franconia.

Diagnosis. - Shell oval slender with distinctly elevated spire; protoconch low-spired, medio-axial; nearly horizontal narrow ramp with rounded transition to whorl flanks; whorl flanks straight to weakly convex, parallel to shell axis; ramp with two spiral furrows; teleoconch whorls with faint spiral striation.

Description. - Slender oval shell with distinctly elevated spire; illustrated specimen (Fig. 32H) comprises protoconch and 4 teleoconch whorls, is $3.2 \mathrm{~mm}$ high and $1.5 \mathrm{~mm}$ wide; whorl flanks straight to slightly convex, parallel to shell axis; narrow ramp with rounded edge passing gradually into whorl face; two spiral furrows on ramp including delimiting furrow; very faint spiral striation on whorl flanks; rounded transition to base; base with very faint spiral striation; aperture poorly preserved, elongated, tear-drop shaped, adapically narrow and abapically rounded; aperture is about $40 \%$ of overall shell height; protoconch deeply sunken into first teleoconch whorl; protoconch diameter $0.26 \mathrm{~mm}$; protoconch smooth, trans- to slightly medioaxial, low-spired; protoconch consisting of about 2 smooth whorls; short umbilical ledge at transition to teleoconch whorls.

Remarks. - Sinuarbullina gnaszynensis Kaim, 2004 from the Bathonian of Poland is more slender, exhibits a less distinct 


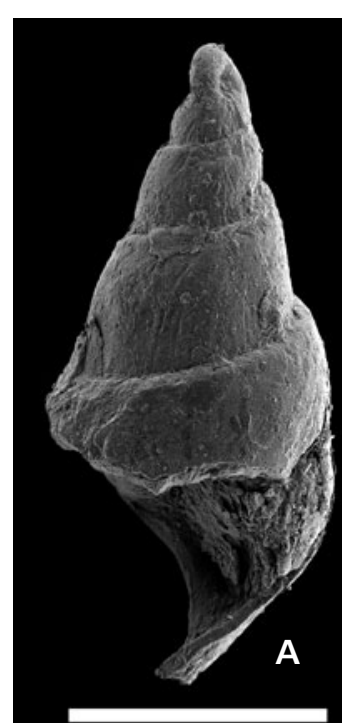

$1 \mathrm{~mm}$

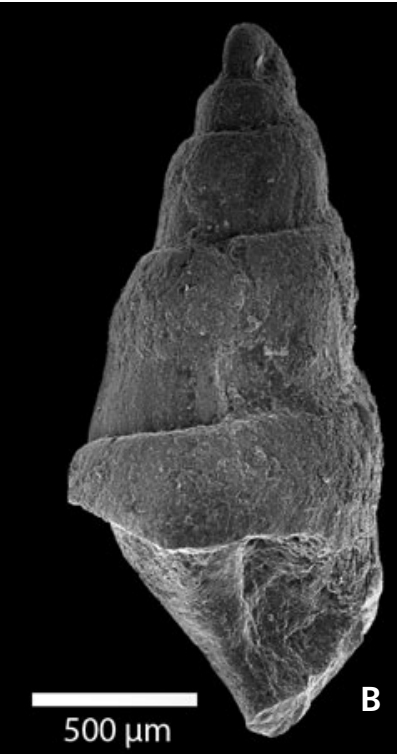

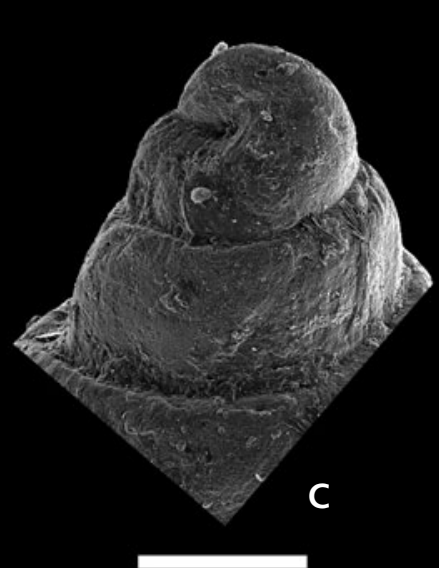

$300 \mu \mathrm{m}$

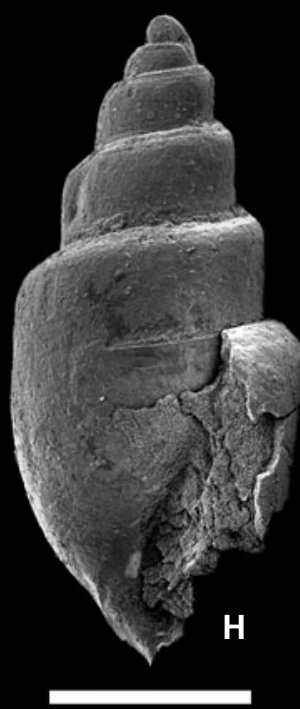

$1 \mathrm{~mm}$

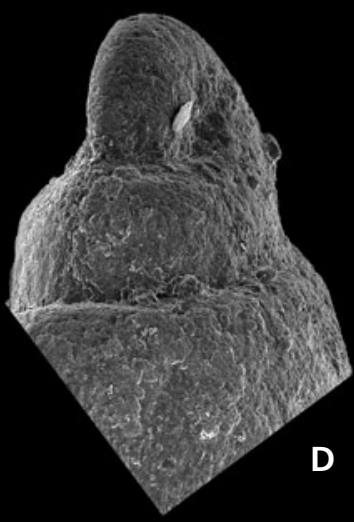

$100 \mu \mathrm{m}$

\section{D}

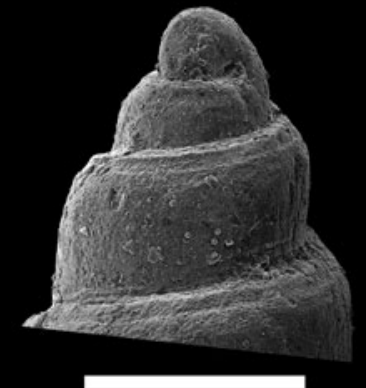

$500 \mu \mathrm{m}$

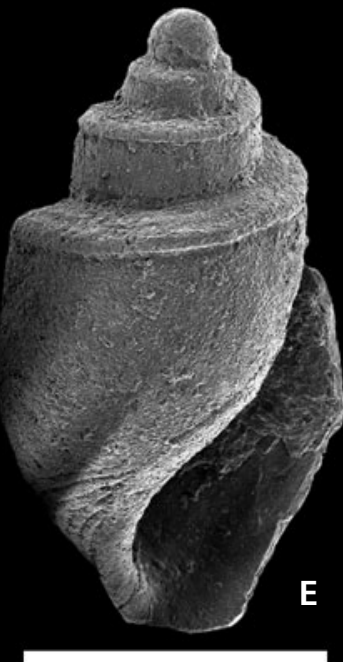

$1 \mathrm{~mm}$

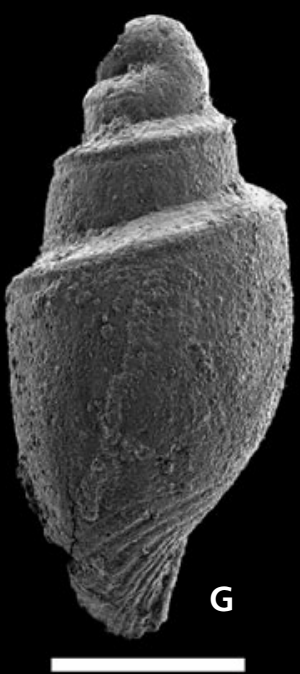

$500 \mu \mathrm{m}$

Figure 32. A - Sinuarbullina mistelgauensis Schulbert, Nützel \& Gründel sp. nov., paratype, BSPG 2011 XLII 193, $450 \mathrm{~cm}$ below Lytoceras bed. - C - Sinuarbullina mistelgauensis Schulbert, Nützel \& Gründel sp. nov., paratype, BSPG 2011 XLII 194, $450 \mathrm{~cm}$ below Lytoceras bed. - B, D - Sinuarbullina mistelgauensis Schulbert, Nützel \& Gründel sp. nov., holotype, BSPG 2011 XLII 119, $310 \mathrm{~cm}$ below Lytoceras bed. •E, F-Striactaeonina richterorum Schulbert, Nützel \& Gründel sp. nov., holotype, BSPG 2011 XLII 201, 7 m above Lytoceras bed. $\bullet$ G - Striactaeonina richterorum Schulbert, Nützel \& Gründel sp. nov., paratype, BSPG 2011 XLII 202, 7 m above Lytoceras bed. • H-J - Striactaeonina waltschewi Schulbert, Nützel \& Gründel sp. nov., holotype, BSPG 2011 XLII 178, $300 \mathrm{~cm}$ below Lytoceras bed. 
ramp and a more tilted aperture. Sulcoactaeon laevis Gründel, Nützel \& Schulbert, 2007 from the Aalenian of N Germany is similar but lacks a distinct spiral furrow on the ramp.

Occurrence. - Late Toarcian.

\section{Striactaeonina richterorum Schulbert, Nützel \& Gründel sp. nov.}

Figure 32E-G

2007a Cylindrobullina sp. nov. - Gründel, p. 248, fig. 3E.

Types. - Holotype BSPG 2011 XLII 201, $7 \mathrm{~m}$ above Lytoceras bed, Fig. 32E, F; 3 paratypes: BSPG 2011 XLII 202, $7 \mathrm{~m}$ above Lytoceras bed, Fig. 32G; BSPG 2011 XLII 21, $5 \mathrm{~m}$ above Lytoceras bed; BSPG 2011 XLII 23, $5 \mathrm{~m}$ above Lytoceras bed.

Type horizon and locality. - Early Aalenian, Opalinuston Formation, Mistelgau clay pit, Oberfranken, Germany.

Material. - Four type specimens.

Etymology. - In honour of Margaretha and Hans Richter, grandparents of first author, who triggered his interest for science.

Diagnosis. - Shell oval with distinctly elevated, gradate spire; distinct, slightly oblique subsutural ramp and strengthened edge with delimiting furrow; protoconch transaxial; base convex, with distinct spiral furrows; aperture acute adapically and broadly rounded abapically.

Description. - Shell oval, moderately elongated, spindle-like; illustrated specimen (Fig. 32E) consists of protoconch and three teleoconch whorls, is $2.1 \mathrm{~mm}$ high and $1.2 \mathrm{~mm}$ wide; broad, nearly horizontal to slightly oblique ramp; distinct spiral furrow demarcates ramp; edge of ramp with distinct bulge; whorl face smooth, almost straight, cylindrical, nearly parallel to shell axis; rounded transition to base; 6-7 spiral furrows on central part of base; aperture teardrop shaped with narrow adapical and rounded abapical part; columellar area covered by reflexed inner lip; aperture comprises about $60 \%$ of total shell height; protoconch smooth, low-spired, comprising about 2 whorls, diameter $0.2 \mathrm{~mm}$; protoconch nearly transaxial, deeply sunken into first teleoconch whorl.

Remarks. - Gründel (2007a, fig. 3E) illustrated a juvenile specimen of this species as Cylindrobullina sp. nov. from the late Toarcian of N Germany. This specimen exhibits 2-3 very faint spiral furrows on the ramp, which are not visible in our material from Mistelgau.
Occurrence. - Early Aalenian.

Family Bullinidae Gray, 1850

\section{Genus Parvulactaeon Gründel, 1997c}

Type species. - Parvulactaeon spiralocostata Gründel, 1997c, Aalenian, North Germany.

\section{Parvulactaeon spiralocostata Gründel, 1997c}

Figure $33 \mathrm{~A}-\mathrm{G}$

1997c Parvulactaeon spiralocostata sp. nov.; Gründel, p. 190 , pl. 5, figs $13-15$, pl. 6 , fig. 1.

2012b Parvulactaeon spiralocostata. - Gründel \& Nützel, p. 45 , figs $12 \mathrm{a}-\mathrm{c}$.

Material. - 6 specimens; BSPG 2011 XLII 67, $320 \mathrm{~cm}$ below Lytoceras bed, Fig. 33A, D; BSPG 2011 XLII 65, $320 \mathrm{~cm}$ below Lytoceras bed, Fig. 33B, C, E; BSPG 2011 XLII 103, $320 \mathrm{~cm}$ below Lytoceras bed, Fig. 33F, G; BSPG 2011 XLII 112, $610 \mathrm{~cm}$; BSPG 2011 XLII 129, $290 \mathrm{~cm}$; BSPG 2011 XLII 4, $290 \mathrm{~cm}$.

Description. - Shell egg-shaped, low-spired; illustrated specimen (Fig. 33A) $1.7 \mathrm{~mm}$ high and $1.1 \mathrm{~mm}$ wide; teleoconch whorls convex; 1.5-2 teleoconch whorls preserved; distinct horizontal ramp, demarcated by angulation from whorl face; ramp with subsutural shallow depression; 12-14 distinct spiral grooves on whorl face; grooves evenly distributed on whorl face; first adapical groove slightly broader than the following ones; grooves also present on base; aperture not preserved in our material; smooth heterostrophic protoconch with $0.44 \mathrm{~mm}$ diameter; medio-axial to almost coaxial orientation; spire of protoconch covered by first teleoconch whorl; abrupt transition between protoconch and teleoconch.

Remarks. - This is the type species of Parvulactaeon, which was first described from the early Aalenian of bore Aulosen (NE Germany) (Gründel 1997c). Gründel's (1997c, 2007a) material has somewhat more spiral grooves but is otherwise very similar.

Occurrence. - Late Toarcian and early Aalenian.

\section{Parvulactaeon imprimum Schulbert, Nützel \& Gründel sp. nov. \\ Figure 34A-G}

2007a Parvulactaeon? sp. nov. 2. - Gründel, p. 250, figs $4 \mathrm{~B}, \mathrm{C}$. 


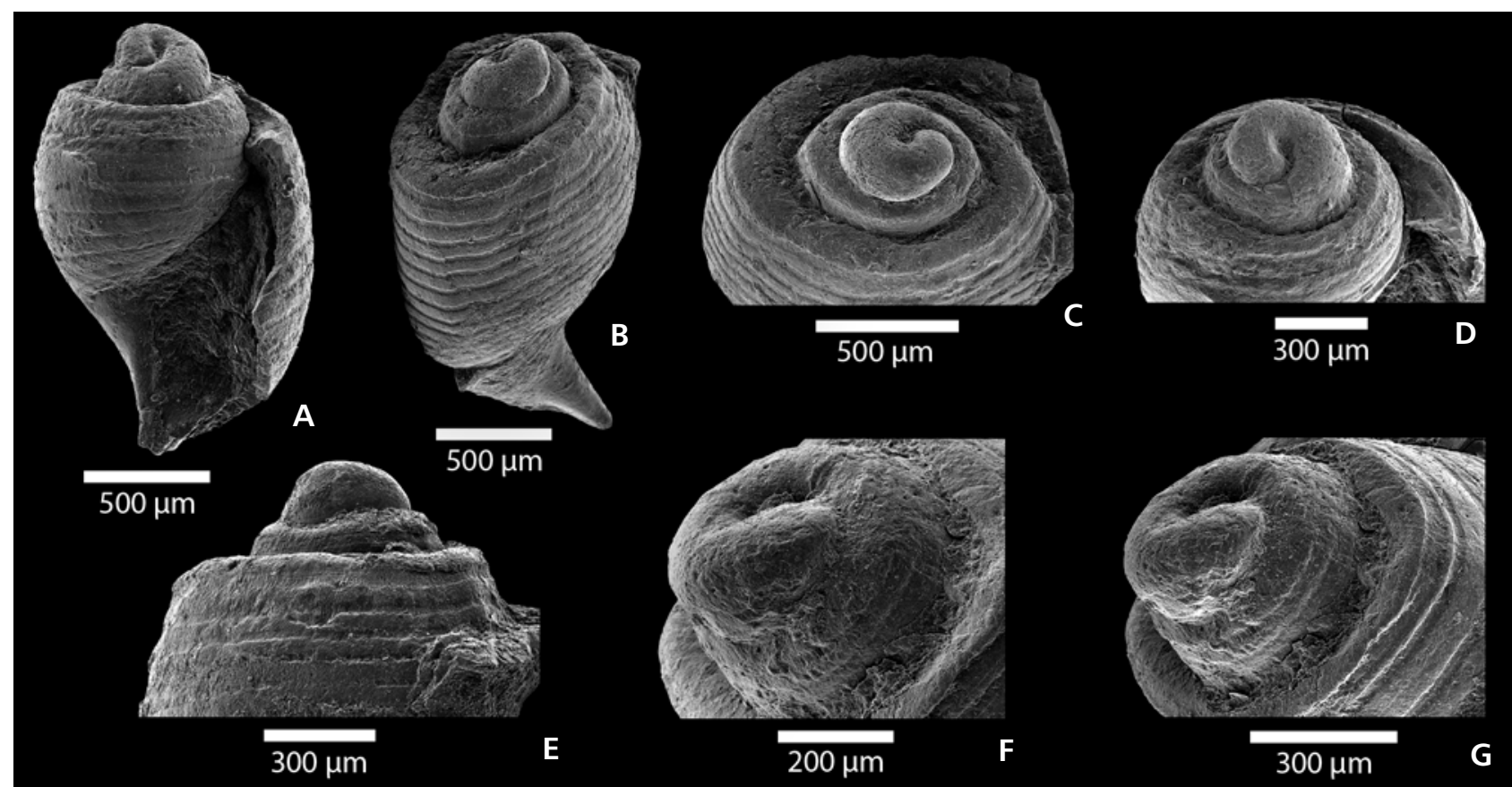

Figure 33. A, D - Parvulactaeon spiralocostata Gründel 1997c, BSPG 2011 XLII 67, $320 \mathrm{~cm}$ below Lytoceras bed. • B, C, E - Parvulactaeon spiralocostata, paratype, BSPG 2011 XLII 65, $320 \mathrm{~cm}$ below Lytoceras bed. • F, G - Parvulactaeon spiralocostata Gründel, 1997c, BSPG 2011 XLII $103,320 \mathrm{~cm}$ below Lytoceras bed.

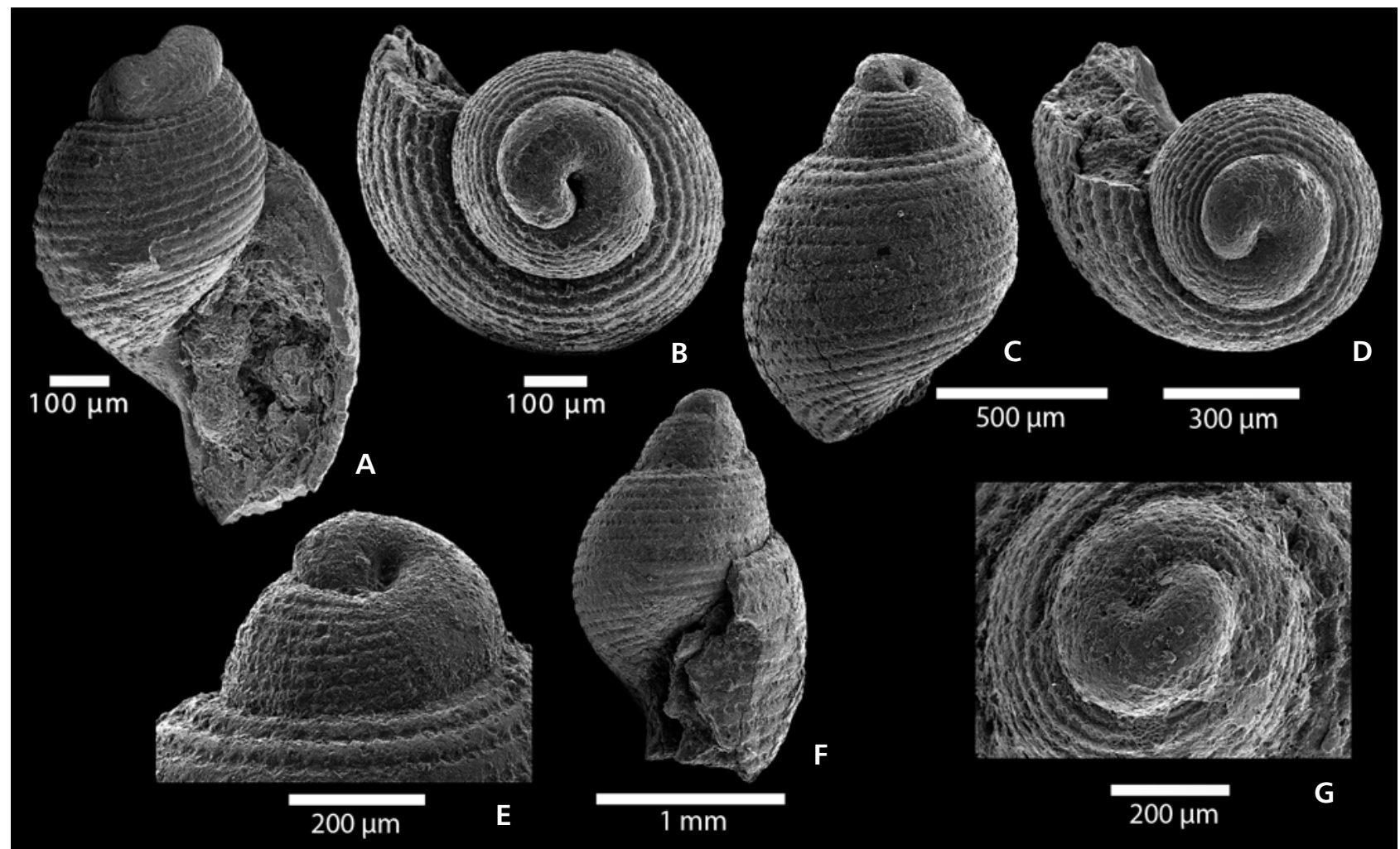

Figure 34 Parvulactaeon imprimum Schulbert, Nützel \& Gründel sp. nov. • A, B - paratype, BSPG 2011 XLII 207, $600 \mathrm{~cm}$ above Lytoceras bed. - C, E - BSPG 2011 XLII 16, 5 m above Lytoceras bed. • D - Parvulactaeon imprimum Schulbert, Nützel \& Gründel, BSPG 2011 XLII 17,5 m above Lytoceras bed. • F, G - Parvulactaeon imprimum Schulbert, Nützel \& Gründel, BSPG 2011 XLII 75, $140 \mathrm{~cm}$ below Lytoceras bed. 


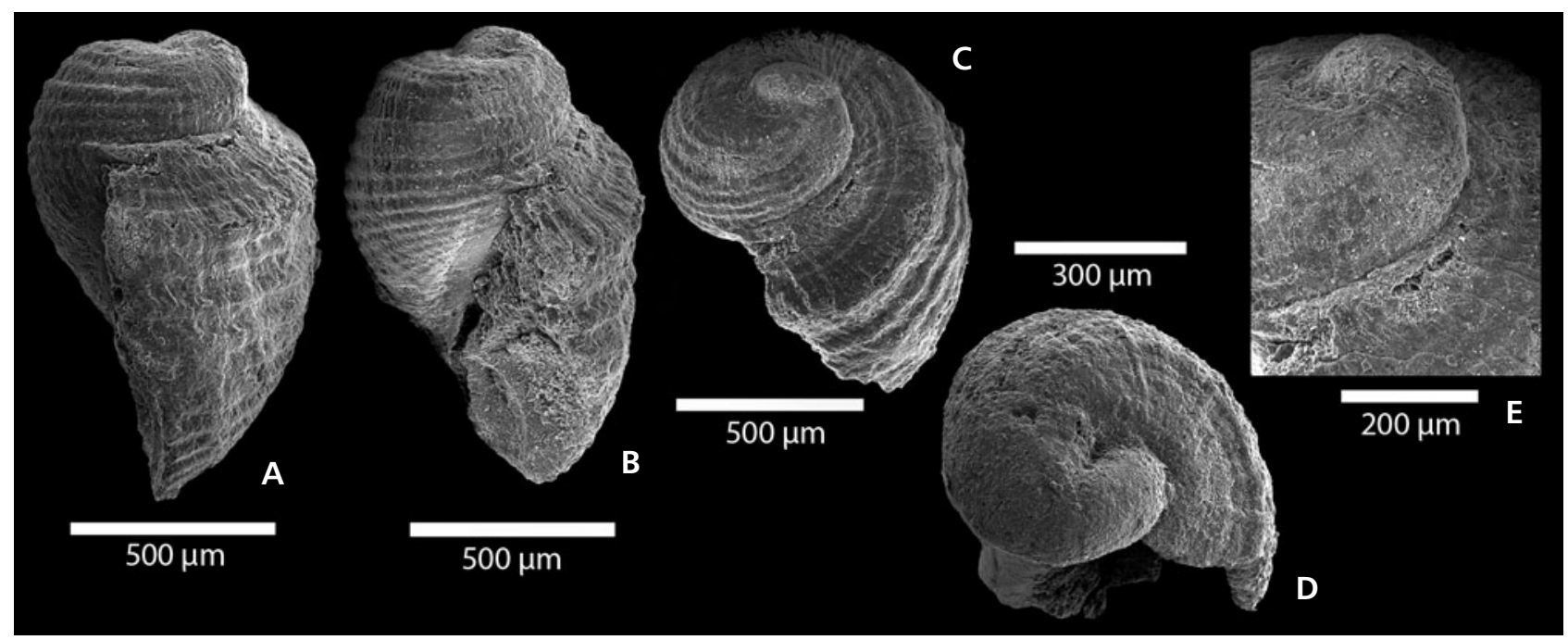

Figure 35. Parvulactaeon inclinatum Schulbert, Nützel \& Gründel sp. nov. • A-C, E - holotype, BSPG 2011 XLII 166, $110 \mathrm{~cm}$ below Lytoceras bed. - D - paratype, BSPG 2011 XLII 15, 5 m above Lytoceras bed.

Types. - Holotype BGR X 13088, Gründel (2007a, p. 250, figs 4B, C); 7 paratypes from Mistelgau: BSPG 2011 XLII 3, $290 \mathrm{~cm}$; BSPG 2011 XLII 14, 16, 17, 19, $5 \mathrm{~m}$ above $L y$ toceras bed; BSPG 2011 XLII 75, $140 \mathrm{~cm}$ below Lytoceras bed; BSPG 2011 XLII 207, $600 \mathrm{~cm}$ above Lytoceras bed, Fig. 34A, B.

Type horizon and locality. - Early Aalenian, Opalinuston Formation, Bore Aulosen 8/59, 720.0-729.0 m (see Gründel 2007a); paratypes from Mistelgau clay pit, Oberfranken, Germany.

Material. - Holotype and 7 paratypes from Mistelgau.

Etymology. - After Latin imprimum for the impressionlike spirals.

Diagnosis. - Species of Parvulactaeon with pitted spiral grooves and very weak subsutural ramp.

Description. - Shell oval, low-spired; illustrated specimen (Fig. 34A) consists of 1.5 teleoconch whorls, is $0.5 \mathrm{~mm}$ wide and $0.8 \mathrm{~mm}$ high; whorls convex with periphery at height of suture; suture distinct; ramp very narrow, shoulder-like, almost absent; teleoconch whorls ornamented with 15-18 prominent spiral cords separated by pitted spiral grooves; prosocline growth lines intersect with furrows and form oval impressions (pits); base convex; aperture higher than wide; protoconch smooth heterostrophic, almost coaxial; protoconch $0.24 \mathrm{~mm}$ in diameter.

Remarks. - Schröder (1995, p. 61, pl. 11, figs 7-10) described a very similar and well-preserved shell from the late Aalenian of Hambühren (N Germany) and called it Acta- eon cf. ooliticus Hudleston, 1896. However, Schröder's material exhibits two distinct columellar folds. Parvulactaeon imprimum differs from $P$. spiralocostata by lacking a distinct ramp and by having a generally finer ornamentation. Gründel (2007a) reported this species from the early Aalenian of N Germany as Parvulactaeon? sp. 2.

Occurrence. - Late Toarcian and early Aalenian.

\section{Parvulactaeon inclinatum Schulbert, Nützel \& Gründel sp. nov.}

Figure 35A-E

2007a Parvulactaeon sp. nov. 1. - Gründel, p. 249, fig. 4A.

Types. - Holotype BSPG 2011 XLII 166, $110 \mathrm{~cm}$ below Lytoceras bed (Fig. 35A-C, E); 2 paratypes: BSPG 2011 XLII 15, 18, $5 \mathrm{~m}$ above Lytoceras bed.

Type horizon and locality. - Early Aalenian, Opalinuston Formation, Mistelgau clay pit, Oberfranken, Germany.

Material. - Three specimens, holotype and two paratypes.

Etymology. - Latin, for the inclined ramp.

Diagnosis. - Parvulactaeon species with coarse teleoconch ornament of pitted spiral furrows that separate ribbons; broad and distinctly inclined ramp on second teleoconch whorl; protoconch deeply sunken and only slightly elevated above first teleoconch whorl.

Description. - Shell oval, low-spired; the holotype is 
$1.1 \mathrm{~mm}$ high and $0.7 \mathrm{~mm}$ wide; teleoconch convex with 1.5 whorls preserved; ramp very broad and nearly horizontal forming a plateau on first teleoconch whorl; ramp getting steeper on younger teleoconch whorls; suture distinct; ramp edge to whorl face rounded; whorls convex; 4 primary spiral cords on ramp; 6 pronounced spiral cords on whorl face; base convex, exhibiting about 6 to 10 spiral cords; weak growth-lines opisthocline on ramp, prosocyrt on whorl face; aperture elongated oval, but poorly preserved.

Remarks. - Parvulactaeon inclinatum has a coarser ornament of spiral furrows and ribs than $P$. spiralocostata and P. imprimum. Parvulactaeon inclinatum has a broad and distinctly inclined $\operatorname{ramp}\left(\mathrm{ca} 45^{\circ}\right)$ on the second teleoconch whorl. By contrast, $P$. imprimum lacks a distinct ramp and $P$. spiralocostata has an almost horizontal ramp from the early teleoconch onward. The protoconch of Parvulactaeon inclinatum is deeply sunken and only slightly elevated above the first teleoconch whorl. Gründel (2007a) reported this species from the early Aalenian of N Germany as Parvulactaeon sp. nov. 1 . This specimen resembles the material from Mistelgau but has a broad depression below the ramp that is absent in the material from Mistelgau.

Occurrence. - Early Aalenian.

\section{Discussion}

The present collection from the late Toarcian/early Aalenian of Franconia yields 44 gastropod species including 9 species in open nomenclature. All species described here, except Eucyclus capitaneus are present in the Mistelgau clay pit. Therefore, this occurrence has yielded the most diverse gastropod assemblage known from this period of time in Central Europe. To some degree, this reflects the sampling intensity and especially sampling by wet sieving of bulk samples. The following species are reported herein:

Laevitomaria? cf. subtilis [Münster, 1844 in Goldfuss (1844)]

Pleurotomaria quenstedti Goldfuss, 1844

Pleurotomaria escheri Goldfuss, 1844

Discohelix guembeli von Ammon, 1892

Eucyclus capitaneus [zu Münster, 1844 in Goldfuss (1844)]

Eucycloidea tenuistria [zu Münster, 1844 in Goldfuss (1844)]

Mistelgauia monarii Schulbert \& Nützel sp. nov.

Costatrochus subduplicatus (d'Orbigny, 1850)

Neritopsis opalina Brösamlen, 1909

Coelodiscus minutus (Schübler in Zieten, 1833)

Caenogastropod larval shell

Cryptaulax armatum (Goldfuss, 1843)
Procerithium brandi (Walther, 1951)

Procerithium compactum Gründel, 1999c

Toarctocera subpunctata [zu Münster, 1844 in Goldfuss (1844)]

Unident. stromboid

Ueckeritzella sp. 1

Ueckeritzella sp. 2

Palaeorissoina maeuseri Gründel, 1999a

Bralitzia sp.

Kalchreuthia leyerbergensis (Krumbeck, 1925)

Lamelliphorus flexuosus [zu Münster, 1844 in Goldfuss (1844)]

Purpurina sp.

Maturifusus sp.

Tricarilda sp.

Jurilda zapfi Schulbert, Nützel \& Gründel sp. nov.

Franconicilda juliae Schulbert \& Nützel sp. nov.

Carinathilda? dieneri Schulbert \& Nützel sp. nov.

Promathildia krumbecki (Kuhn, 1935)

Turritelloidea opalina (Quenstedt, 1858)

Proacirsa nuda [zu Münster, 1844 in Goldfuss (1844)]

Conusella convexa Schulbert \& Nützel sp. nov.

Graphis weissi (Gründel, 1999d)

Falsoebala urdatica Gründel, Nützel \& Schulbert in Gründel, 2007a

Hummelgauia microstriata Schulbert \& Nützel sp. nov.

Bandellina? sp.

Cossmannina eggmaieri Schulbert \& Nützel sp. nov.

Costactaeon schroederi Gründel, 1997c

Sinuarbullina mistelgauensis Schulbert, Nützel \& Gründel sp. nov.

Striactaeonina waltschewi Schulbert, Nützel \& Gründel sp. nov.

Striactaeonina richterorum Schulbert, Nützel \& Gründel sp. nov.

Parvulactaeon spiralocostata Gründel, 1997c

Parvulactaeon imprimum Schulbert, Nützel \& Gründel sp. nov.

Parvulactaeon inclinatum Schulbert, Nützel \& Gründel sp. nov.

The alpha diversity from the Mistelgau clay pit is exceptionally high for the Opalinuston Formation. For instance, Etter (1990) listed only six gastropod species from the Aalenian of N Switzerland, all of them are also present in Mistelgau. The lower gastropod species richness in $\mathrm{N}$ Switzerland could be explained with the palaeogeographic situation; this area was more distant from land areas and probably also deeper than the Mistelgau area. Probably, oxygen depletion was also more severe in the Swiss sites. As in Mistelgau, Etter (1990) noted that Toarctocera subpunctata is an important element of the fauna (see below).

The gastropod fauna from Mistelgau is clearly dominated by Caenogastropoda and Heterobranchia. Vetigas- 
tropoda are present with a few taxa only and Neritimorpha are present with a single specimen representing Neritopsis opalina. This dominance of the "more advanced" gastropod clades Caenogastropoda and Heterobranchia is typical of Mesozoic marine soft bottom communities. Gastropods are the most diverse and most abundant (with the exception of the bivalve Bositra buchi) benthic group of the macroand meiofauna. With 20 species, Heterobranchia are the most diverse subclass of the gastropod fauna from Mistelgau. The most abundant species belong to the Caenogastropoda: Coelodiscus minutus, Toarctocera subpunctata, Palaeorissoina maeuseri and Cryptaulax armatum. Vetigastropoda are not really abundant, especially in washed residues. Vetigastropod species are relatively large, especially the Pleurotomaria species, and were primarily found by surface collections. However, most of the gastropod species present in Mistelgau are small i.e., ca $1 \mathrm{~cm}$ or smaller. Many of these small-sized species were only found in washed residues and never by surface collecting in the field. The small size of most of the gastropods from Mistelgau is not result of stunting or dwarfism. Most of the species are primarily small as is the case in the majority of modern snails (e.g., Brayard et al. 2010).

The Jurensismergel and the Opalinuston consist of dark marine clays mainly devoid of sand or coarser clastic material. This facies suggests a considerable distance to the coastline of the Bohemian Massif. We found no evidence for wave agitation and assume that the clay stones exposed in the Mistelgau clay pit were deposited well below storm wave base (with exception of the lowermost upper Toarcian, haugia Zone). There is no evidence for photosynthetic benthos in the studied fauna. Besides gastropods, the benthic fauna of Mistelgau consists of bivalves, abundant ophiuroid ossicles (Kutscher 1996; own observation), scaphopods, serpulids, solitary azooxanthellate corals and crustaceans (Förster 1980). Bivalves form an important part of the studied fauna, especially small nuculids and thin-shelled Bositra buchi, which is superabundant throughout. However, the washed residues yielded only abundant shell fragments of Bositra because the very thin shells break easily. Thus, a count of specimens is not possible. The mode of life of Bositra buchi is disputed: pseudoplanktonic, swimming or opportunistic benthos. Etter (1996) and Röhl (1998) favoured the latter interpretation. Facies and fauna of the sediments exposed in the Mistelgau clay pit suggest soft bottom conditions with the substrate being soupy, at least temporarily. The small size of most of the fossils could be in part an adaption to these soft bottom conditions ( $c f$. Etter 1995). Moreover, the morphology of some taxa could also represent adaptations to the soft substrate. For instance, the very long apertural spines of Toarctocera subpunctata were interpreted as following "snowshoe strategy" (Etter 1990, 1995, 1996; Gründel et al. 2009). The small solitary coral Thecocyathus also shows adaptation to the soft sediment by its cupshaped morphology.

Toarctocera subpunctata is one of the most abundant gastropods in late Toarcian/early Aalenian clay stones of South Germany and N Switzerland. As mentioned, it is also the most abundant benthic gastropod species in the Mistelgau clay pit and in N Switzerland (Etter 1990, 1995; Gründel et al. 2009). Mass accumulations were reported from the abandoned clay pit near Heiningen in Baden Württemberg (Gründel et al. 2009, fig. 2a). As mentioned above, the extremely long apertural spines of fully grown, mature $T$. subpunctata were interpreted as adaptation to soft bottom conditions, i.e. these spines hindered sinking into the muddy substrate ("snowshoe strategy") (Etter 1990, 1995, 1996). The long and thin spines show that Toarctocera subpunctata was not very mobile (Gründel et al. 2009). The Recent Aporrhais pespelecani lives as shallow burrower and has an anterior and posterior tube-like connection to the sea-water (e.g., Willmann 1989). Even seasonal burrowing has been substantiated for Recent Aporrhais (Perron 1978, Roy 1994). Aporrhais pespelecani stays at one place for several days and feeds on detritus and microbes. When this place has been exploited, it moves to another place. A similar shallow infaunal micro-carnivorous to detritovorous life style can also be assumed for Toarctocera subpunctata although an epifaunal life style cannot be excluded. A shallow infaunal life position was also assumed for the aporrhaid Quadrinervus mosensis, one of the most abundant benthic animals of the late Jurassic Kimmeridge Clay in England (Oschmann 1994).

The tiny Coelodiscus minutus is the most abundant gastropod in the studied samples from Mistelgau. As in Bositra buchi, the mode of life of this gastropod is disputed. Bandel \& Knitter (1983) and Bandel \& Hemleben (1987) advocated a holoplanktic mode of life, whereas Etter (1996) and others interpret it as benthic and adapted to dysoxic conditions. At this point we follow, Bandel \& Hemleben's (1987) interpretation as holoplanktonic, especially because $C$. minutus is highly abundant in clearly oxygen depleted settings of the Posidonienschiefer, e.g., the Unterer and Oberer Stein as was also noted by Röhl (1998) and Teichert (2009).

Besides the soft bottom conditions, oxygen concentration was probably another important constraint influencing the benthic communities of the Jurensismergel and the Opalinuston. Etter (1995) showed that composition and diversity of the benthic fauna of the Opalinuston in N Switzerland was primarily controlled by oxygen availability in a generally dysaerobic environment. Some parts of the here studied section at Mistelgau exhibits high amounts of pyrite (including the preservation of the fossils as pyritic steinkerns). Thus, oxygen concentrations were low in the sediment. As it is common in clay sediments, oxygen was absent just a shortly beneath the sediment/water boundary. 
However, the presence trace fossils, pyritic tubes and infaunal bivalves (nuculids) as well as the overall homogeneity of the sediment, endobenthic life was, at least, periodically possible. Burrows have a diameter from millimetres to one centimetre and are up to $10 \mathrm{~cm}$ in length. Some of the small gastropods were probably also infaunal to semiinfaunal $e . g$., the architectibranchs. The relatively high diversity and abundance of the benthos suggest aerobic or dysaerobic conditions, however with possible fluctuations of oxygen concentrations.

The gastropod species are not evenly distributed throughout the section exposed in the Mistelgau clay pit. In the lowermost samples, commonly only Toarctocera subpunctata and Coelodiscus minutus are present. Samples become more and more diverse in the upper parts of the section. This diversity gradient can be seen as recovery of benthic communities after the early Toarcian anoxic event, probably due to rising oxygen concentrations. This gradient will be quantified and treated in a separate study.

Diversity, structure and size of the studied gastropod fauna are analogous to the gastropod fauna of the Pliensbachian Amaltheenton Formation of Franconia i.e., prior to the early Toarcian anoxic event (Nützel \& Kiessling 1997, Gründel \& Nützel 1998, Nützel \& Gründel submitted). These gastropod faunas as present in the clay pits of Kalchreuth and Buttenheim consist also of about 40 species with a strong dominance of a few species and a dominance of Caenogastropoda and Heterobranchia. However, no gastropod species and only several genera are shared between the here studied fauna and that of the older (Pliensbachian) Amaltheenton Formation of Franconia.

Only a few gastropod species have been reported from the early Toarcian Posidonienschiefer Formation underlying the here studied section at Mistelgau. Riegraf et al. (1984, p. 40) listed 11 species level gastropod taxa from the Posidonienschiefer of SW Germany, amongst it three Coelodiscus species which represent putative planktonic gastropods (see Kauffman 1981 and Etter 1995 for a different opinion). Among these species, Coelodiscus minutus, Procerithium brandi and Eucyclus capitaneus range into the late Toarcian and early Aalenian. However, the occurrences of the latter two species as well as that of the other gastropods from the Posidonienschiefer except Coelodiscus minutus need a modern revision. In conclusion the gastropod fauna of Jurensismergel and Opalinuston reflect re-diversification and turnover after the early Toarcian extinction event.

\section{Acknowledgements}

We are especially grateful to Walter Diener, Helmut Zapf (Naturwissenschaftliche Gesellschaft Bayreuth), Joachim Rabold and
Stefan Eggmaier (Urwelt-Museum Oberfranken, Bayreuth). We thank Joachim Gründel (Berlin) and Janos Szabó (Budapest) for their careful reviews. A.N. acknowledges the Deutsche Forschungsgemeinschaft for financial support (project NU 96/11-1).

\section{References}

Ammon, L. von 1892. Die Gastropodenfauna des HochfellenKalkes und über Gastropoden-Reste aus Ablagerungen von Adnet, vom Monte Nota und den Raibler Schichten. Anhang. 5. Die Gastropoden aus dem Nürtinger Sandstein. 6. Eine neue Scheibenschnecke (Discohelix) aus dem Frankenjura. Geognostische Jahreshefte 5, 161-219.

AndreAE, A. 1887. Die Glossophoren des Terrain a Chailles der Pfirt. Abhandlungen zur geologischen Specialkarte von Elsass-Lothringen 4, 1-45.

BANDEL, K. 1993. Caenogastropoda during Mesozoic times. Scripta Geologica, special issue 2, 7-56.

BANDEL, K. 1994. Triassic Euthyneura (Gastropoda) from the St. Cassian Formation (Italian Alps) with a discussion on the evolution of the Heterostropha. Freiberger Forschungshefte $C$ 452, 79-100.

BANDEL, K. 1995. Mathildoidea (Heterostropha, Gastropoda) from the Upper Triassic St. Cassian Formation. Scripta Geologica 111, 1-83.

BANDEL, K. 1996. Some heterostrophic gastropods from Triassic St. Cassian Formation with a discussion on the classification of the Allogastropoda. Paläontologische Zeitschrift 70, 325-365.

BANDEL, K. 2005. Living fossils among tiny Allogastropoda with high and slender shell from the reef environment of the Gulf of Aquba with remarks on fossil and recent relatives. Mitteilungen des Geologisch-Paläontologischen Instituts der Universität Hamburg 89, 1-24.

BAndel, K. \& FrÝDA, J. 1998. The systematic position of the Euomphalidae. Senckenbergiana lethaea 78, 103-131.

Bandel, K., Gründel, J. \& MAXwell, P. 2000. Gastropods from the Upper Jurassic/early Middle Jurassic of Kaiwara Valley, North Canterbury, New Zealand. Freiberger Forschungshefte C 490, 67-132.

Bandel, K. \& Hemleben, C. 1987. Jurassic heteropods and their modern counterparts (planktonic Gastropoda, Mollusca). Neues Jahrbuch für Geologie und Paläontologie, Abhandlungen 174, 1-22.

BANDEL, K. \& KNitTER, H. 1983. Litho- und biofazielle Untersuchung eines Posidonienschieferprofils in Oberfranken. Geologische Blätter für Nordost-Bayern und angrenzende Gebiete 32, 95-129.

Bouchet, P., Frýda, J., Hausdorf, B., Ponder, W.F., Valdés, Á. \& WARÉN, A. 2005. Working classification of the Gastropoda, 1-397. In Bouchet, P. \& Rocroi, J.-P. (eds) Classification and nomenclator of gastropod families. Malacologia 47.

Brauns, D. 1865. Die Stratigraphie und Paläontographie des südöstlichen Theiles der Hilsmulde auf Grund neuer, bei den Eisenbahnbauten in den Jahren 1861-1864 angestellter Beobachtungen. Palaeontographica 13, 75-146. 
Brayard, A., Nützel, A., Stephen, D.A., Bylund, K.G., Jenks, J. \& Bucher, H. 2010. Gastropod evidence against the Early Triassic Lilliput effect. Geology 38, 147-150. DOI 10.1130/G30553.1

Brösamlen, R. 1909. Beitrag zur Kenntnis der Gastropoden des Schwäbischen Jura. Palaeontographica 56, 177-322.

BurmeISTER, R. 1837. Handbuch der Naturgeschichte, 369-858. Enslin, Berlin.

CASEY, T.L. 1904. Notes on the Pleurotomidae with descriptions of some new genera and species. Transactions of the Academy of Science of St Louis 14, 123-170.

Chartron, C. \& Cossmann, M. 1902. Note sur l'Infralias de la Vendée et specialement sur un gisement situé dans la commune du Simon-la-Vineuse. Bulletin de la Société géologique de France 4, 163-203.

Conti, M.A. \& Szabó, J. 1987. Comparison of Bajocian gastropod faunas from the Bakony Mts. (Hungary) and Umbria (Italy). Annales historico-naturales Musei nationalis Hungarici $79,43-59$.

Cossmann, M. 1885. Contribution à l'étude de la faune de l'étage Bathonien en France (Gastropodes). Mémoirs de la Société géologique de France 3(3), 1-374.

Cossmann, M. 1895-1925a. Essais de Paléoconchologie comparée. Livraison 1 (1895), 159 pp.; 7 (1906): 261 pp.; 8 (1909): 348 pp.; 9 (1912): 215 pp., 10 (1916): 292 pp. Cossmann \& Rudeval, Paris.

Cossmann, M. 1895b. Contribution à la paleontologie française des terrains jurassiques. Étude sur les Gastropodes. Mémoires de la Société géologique de France 14, 1-167.

Cox, L.R. 1956. Jurassic Mollusca from Peru. Journal of Paleontology 30, 1179-1186.

Cox, L.R. 1960. Thoughts on the classification of the Gastropoda. Proceedings of the Malacological Society of London 33, 239-261.

Cox, L.R. 1969. Gastéropodes Jurassiques du sud-est Tunisien. Annales de Paléontologie (Invertébrés) 40, 243-268.

DALL, W.H. 1889. A preliminary report of the shell-bearing marine mollusks and brachiopods of the southeastern coast of the United States, with illustrations of many of the species. Bulletin of the United States National Museum 37, $1-121$.

Defrance, M.J.L. 1826. Genus Pleurotomaria, 381. In Cuvier, F. (ed.) Dictionnaire des Sciences Naturelles. Paris \& Strasbourg.

Durmortier, E. 1874. Études Paléontologiques sur les Dépots Jurassiques de Bassin du Rhone. 335 pp. Savy, Paris.

DUNKER, W. 1847. Über einige neue Versteinerungen aus verschiedenen Gebirgsformationen. Palaeontographica 1, 128-133.

ERnst, W. 1923. Zur Stratigraphie und Fauna des Lias zeta im nordwestlichen Deutschland. Palaeontographica 65, 1-96.

ETTER, W. 1990. Paläontologische Untersuchungen im unteren Opalinuston der Nordschweiz. 151 pp. Unpublished PhD thesis, Universität Zürich, Switzerland.

ETTER, W. 1995. Benthic diversity patterns in oxygenation gradients: an example from the Middle Jurassic of Switzerland. Lethaia 28, 259-270. DOI 10.1111/j.1502-3931.1995.tb01430.x
ETter, W. 1996. Pseudoplanktonic and benthic invertebrates in the Middle Jurassic Opalinum Clay, northern Switzerland. Palaeogeography, Palaeoclimatology, Palaeoecology 126, 325-341. DOI 10.1016/S0031-0182(96)00036-3

Eudes-Desongchamps, J.A. 1861. Note sur l'utilité distraire des genres Turbo et Purpurina quelques coquilles des terrains jurassiques, et d'en former une nouvell coupe générique sous le nom d'Eucyclus. Bulletin de la Societé Linnéenne de Normandie 5, 119-149.

Fleming, J. 1822. The philosophy of zoology, a general view of the structure, functions and classification of animals. $618 \mathrm{pp}$. Constable \& Co., Edinburgh.

FöRSTER, R. 1980. Krebs-Funde aus dem obersten Lias und dem untersten Dogger von Mistelgau bei Bayreuth, Oberfranken. Geologische Geologische Blätter für Nordost-Bayern und angrenzende Gebiete 30, 73-90.

Fürsich, F.T., Berndt, R., Scheuer, T. \& Gahr, M. 2001. Comparative ecological analysis of Toarcian (Lower Jurassic) benthic faunas from southern France and east central Spain. Lethaia 34, 169-199. DOI 10.1111/j.1502-3931.2001.tb00048.x

Geiger, D., Nützel, A. \& SASaki, T. 2008. Vetigastropoda, 297-330. In Ponder, W.F. \& LindBerg, D.R. (eds) Phylogeny and evolution of the Mollusca. University of California Press, Berkeley, Los Angeles, London.

Goldfuss, A. 1841-1844. Petrefacta Germaniae, Abbildungen und Beschreibungen der Petrefacten Deutschlands und der angränzenden Länder, Teil 3. Molluscorum Gasteropodum Reliquiae. Einkammerige Schnecken der Vorwelt. 128 pp. Arnz \& Comp., Düsseldorf.

Golikov, A.N. \& Starobogatov, Y.I. 1987. Sistema otriada Cerithiiformes i ego polozhenie v podklasse Pectinibranchia [Systematics of the order Cerithiiformes and its position within the subclass Pectinibranchia]. Vsesoiuznoe soveshchanie po izucheniiu molliuskov (Leningrad) 8, 23-28. [in Russian]

Grateloup, S.D. 1832. Description d'un nouveau genre de coquille, appele Neritopside. Actes de la Société linnéenne de Bordeaux 5(27), 125-131.

GrAY, J.E. 1840a. Shells of molluscous animals. Synopsis of the contents of the British Museum 42, 105-152.

GRAY, J.E. 1840b. A new edition of a Manual of the land and freshwater shells of the British Islands by W. Turton. ix + 324 pp. Longman, Orme, Brown, Green, and Longmans, London.

Gray, J.E. 1847. A list of genera of Recent Mollusca, their synonyms and types. Proceedings of the Zoological Society of London 15, 129-206.

Gray, J.E. 1850. Figures of molluscous animals selected from various authors. Etched for the use of students by M.E. Gray. 219 pp. Longman, Brown, Green \& Longmans, London.

GRÜNDEL, J. 1973. Zur Gastropodenfauna aus dem Dogger. I. Die Gattungen Mathilda und Eucycloidea. Zeitschrift für geologische Wissenschaften 1, 947-965.

GRÜNDEL, J. 1974. Bemerkungen zur Fassung der Gattung Procerithium Cossmann, 1902 und Cryptaulax Tate, 1869 
(Gastropoda, Cerithiacea) im Jura. Zeitschrift für geologische Wissenschaften 2, 729-733.

GRÜNDEL, J. 1976. Zur Taxonomie und Phylogenie der BittiumGruppe. Malakologische Abhandlungen, Staatliches Museum für Tierkunde in Dresden 3, 33-59.

GRÜNDEL, J. 1997a. Zur Kenntnis einiger Gastropoden-Gattungen aus dem französischen Jura und allgemeine Bemerkungen zur Gastropodenfauna aus dem Dogger Mittel- und Westeuropas. Berliner geowissenschaftliche Abhandlungen, Reihe E 25, 69-129.

GRÜNDEL, J. 1997b. Heterostropha (Gastropoda) aus dem Dogger Norddeutschlands und Nordpolens. I. Mathildoidea (Mathildidae). Berliner geowissenschaftliche Abhandlungen, Reihe E 25, 131-175.

GRÜNDEL, J. 1997c. Heterostropha (Gastropoda) aus dem Dogger Norddeutschlands und Nordpolens. III. Opisthobranchia. Berliner geowissenschaftliche Abhandlungen, Reihe E 25, $177-223$.

GRÜNDEL, J. 1998a. Archaeo- und Caenogastropoden aus dem Dogger Deutschlands und Nordpolens. Stuttgarter Beiträge zur Naturkunde, Serie B 260, 1-39.

GRÜNDEL, J. 1998b. Heterostropha (Gastropoda) aus dem Dogger Norddeutschlands und Nordpolens. II. Weitere Allogastropoda. Freiberger Forschungshefte, C474, 1-37.

GRÜNDEL, J. 1999a. Truncatelloidea (Littorinimorpha, Gastropoda) aus dem Lias und Dogger Deutschlands und Nordpolens. Berliner Geowissenschaftliche Abhandlungen, Reihe E 30, 89-119.

GRÜNDEL, J. 1999b. Gastropoden aus dem höheren Lias von Grimmen (Vorpommern) (Deutschland). Archiv für Geschiebekunde 2, 629-672.

GRÜNDEL, J. 1999c. Procerithiidae (Gastropoda) aus dem Lias und Dogger Deutschlands und Polens. Freiberger Forschungshefte C 481, 1-37.

GRÜNDEL, J. 1999d. Neue Arten der Heterostropha (Gastropoda) aus dem Dogger Deutschlands und Nordpolens. Greifswalder Geowissenschaftliche Beiträge 6, 291-299.

GRÜNDEL, J. 2000. Gordenellidae n. fam., eine neue Gastropoden-Familie aus dem Dogger und Malm Europas. Berliner Geowissenschaftliche Abhandlungen, Reihe E 34, $255-267$.

GRÜNDEL, J. 2001a. Gastropoden aus dem Jura der südamerikanischen Anden. Freiberger Forschungshefte C 492, 43-84.

GRÜNDEL, J. 2001b. Neritimorpha und weitere Caenogastropoda (Gastropoda) aus dem Dogger Norddeutschlands und des nordwestlichen Polens. Berliner geowissenschaftliche Abhandlungen, Reihe E 36, 45-99.

GRÜNDEL, J. 2003. Gastropoden aus dem Unteren Lias (OberHettangium bis Unter-Sinemurium) Südwestdeutschlands. Stuttgarter Beiträge zur Naturkunde, Serie B (Geologie und Paläontologie) 340, 1-55.

GRÜNDEL, J. 2005a. Zur Fassung und taxonomischen Stellung der Gattung Turritelloidea Walther, 1951 (Gastropoda, Heterostropha). Neues Jahrbuch für Geologie und Paläontologie, Monatshefte, 321-331.
GRÜNDEL, J. 2005b. Die Gattung Discohelix Dunker, 1847 (Gastropoda) und zur Fassung der Discohelicidae Schröder, 1995. Neues Jahrbuch für Geologie und Paläontologie, Monatshefte, 729-748.

GRÜNDEL, J. 2006. Gastropoden aus dem oberen Bathonium von Luc-sur-Mer/Calvados (Normandie, Frankreich): III. Heterostropha. Freiberger Forschungshefte C 115, 1-30.

GRÜNDEL, J. 2007a. Gastropoden aus dem oberen Toarcium/unteren Aalenium (Jura) von Norddeutschland. Paläontologische Zeitschrift 81, 238-253.

GRÜNDEL, J. 2007b. Gastropoden aus dem unteren Pliensbachium von Feuguerolles (Normandie, Frankreich). Freiberger Forschungshefte C524, 1-34.

GRÜNDEL, J. 2009. Zur Taxonomie der Gattungen Amphitrochus Cossmann, 1907 und Costatrochus n. gen. (Gastropoda, Vetigastropoda, Turbinidae) im Jura. Berliner paläobiologische Abhandlungen 10, 199-214.

Gründel, J., Ebert, M. \& Furze, R. 2011. Die Gastropoden aus dem oberen Aalenium von Geisingen (Süddeutschland). Zitteliana 51, 99-114.

GRÜNDEL, J. \& KaIM, A. 2006. Shallow-water gastropods from late Oxfordian sands on Kleby (Pomeriana, Poland). Acta Geologica Polonica 56, 121-157.

GRÜndel, J. \& Kowalke, T. 2002. Palaeorissoinidae, a new family of marine and brackisch water Rissoidea (Gastropoda, Littorinimorpha). Neues Jahrbuch für Geologie und Paläontologie, Abhandlungen 226(1), 43-57.

GRÜNDEL, J. \& NÜTZEL, A. 1998. Gastropoden aus dem oberen Pliensbachium (Lias delta 2, Zone des Pleuroceras spinatum) von Kalchreuth östlich Erlangen (Mittelfranken). Mitteilungen der Bayerischen Staatssammlung für Paläontologie und historische Geologie 38, 63-96.

GRÜNDEL, J. \& NÜTZEL, A. 2012a. Evolution and classification of Mesozoic mathildoid gastropods. Acta Palaeontologica Polonica. DOI 10.4202/app.2012.0052

GRÜNDEL, J. \& NÜTZEL, A. 2012b. On the early evolution (late Triassic to late Jurassic) of the Architectibranchia (Gastropoda: Heterobranchia) with a provisional classification. Neues Jahrbuch für Geologie und Paläontologie, Abhandlungen 264, 31-59. DOI 10.1127/0077-7749/2012/0230

Gründel, J., Nützel, A. \& Schulbert, C. 2009. Toarctocera (Gastropoda, Aporrhaidae): a new genus from the Jurassic (Toarcian/Aalenian) of South Germany and the early evolutionary history of the family Aporrhaidae. Paläontologische Zeitschrift 83, 533-543. DOI 10.1007/s12542-009-0037-1

Guzhov, A.V. 2009. Revision of Discohelix Dunker, 1847 (Gastropoda: Discohelicidae) from Jurassic of Russia and Ukraine. Bulletin of Moscow Society of Naturalists, Geological section 84, 47-57.

HAAs, O. 1953. Mesozoic invertebrate faunas of Peru. Bulletin of the American Museum of Natural History 101, 1-328.

HäGELE, G. 1997. Juraschnecken. 144 pp. Goldschneck Verlag, Weinstadt.

HASZPRUNAR, G. 1985. The Heterobranchia - a new concept of the phylogeny of the higher Gastropoda. Zeitschrift für 
zoologische Systematik und Evolutionsforschung 23, 15-37. DOI 10.1111/j.1439-0469.1985.tb00567.x

Heller, F. 1953. Ein Mystriosaurus-Fund im Lias epsilon von Mistelgau. Geologische Blätter für Nordost-Bayern und angrenzende Gebiete 6, 146-148.

Heller, F. 1956. Fund eines Ichthyosaurier-Unterkiefers im Lias epsilon von Mistelgau. Geologische Blätter für NordostBayern und angrenzende Gebiete 6, 40-41.

Hickman, C.S. 1984. Pleurotomaria: Pedigreed perseverance?, 225-231. In Eldredge, N. \& Stanley, S.M. (eds) Living Fossils. Springer, New York, Berlin Heidelberg, Tokyo.

Hudleston, W.H. 1887-1896. A monograph of the British Jurassic Gasteropoda. Part I. A monograph of the Inferior Oolite Gasteropoda. Palaeontographical Society Monographs 40, 1-56 (1887); 41, 57-136 (1888); 42, 137-192 (1889); 43, 193-244, (1890); 45, 225-272 (1892); 46, 273-324 (1893); 48, 325-390 (1894); 49, 391-444 (1895); 50, 445-514 (1896).

JefFeries, R.P.S. \& Minton, P. 1965. The mode of life of two Jurassic species of "Posidonia" (Bivalva). Palaeontology 8, $156-185$

JEFFREYS, J.G. 1867. British conchology. 486 pp. Van Voorst, London.

KaIM, A. 2004. The evolution of conch ontogeny in Mesozoic open sea gastropods. Palaeontologia Polonica 62, 1-182.

KanmaCHER, F. 1798. Adam's Essays on the microscope. The second edition, with considerable additions and improvements. 712 pp. Dillon and Keating, London.

KaufFMAN, E.G. 1981. Ecological reappraisal of the German Posidonienschiefer (Toarcian) and the Stagnant Basin Model, 311-381. In Gray, J., Boucot, A.J. \& Berry, B.N. (eds) Communities of the past. Hutchinson Ross Publishing Company, Stroudsburg, Pennsylvania.

KLÖCKER, P. 1966. Faunistische und feinstratigraphische Untersuchungen an der Lias-Dogger-Grenze am Schönberg bei Freiburg i. Br. Berichte der Naturforschenden Gesellschaft Freiburg im Breisgau 56, 209-248.

Knight, J.B. 1933. The Gastropods of the St. Louis, Missouri, Pennsylvanian outlier: The Trocho-Turbinidae. Journal of Paleontology 7, 30-58.

Knight, J.B., Cox, L.R., Keen, A.M., Batten, R.L., Yochelson, E.L. \& Robertson, R. 1960. Systematic descriptions, I169-I310. In MooRe, R.C. (ed.) Treatise on Invertebrate Paleontology, Part I, Mollusca 1. Geological Society of America and University of Kansas Press, Lawrence.

KoKen, E. 1896. Die Gastropoden der Trias um Hallstadt. Jahrbuch der Kaiserlich-königlichen geologischen Reichsanstalt 46, 37-126.

KoKen, E. 1897. Gastropoden der Trias um Hallstadt. Abhandlungen der Kaiserlich-königlichen geologischen Reichsanstalt 17(4), 1-111.

KRUMBECK, L. 1925. Stratigraphische und faunenkundliche Studie über den untersten Dogger (Schichten des Lytoceras torulosum (Schübl.)) bei Hetzles am Leyerberg unweit Erlangen (Nordbayern). Zeitschrift der Deutschen Geologischen Gesellschaft 77, 1-83.

Kunn, O. 1935. Revision der Opalinuston-(Dogger Alpha)-Fauna in Franken mit Ausschluß der Cephalopoden. Paläontologische Zeitschrift 17, 109-158.

KunN, O. 1936. Die Fauna des Amaltheentons (Lias delta) in Franken. Neues Jahrbuch für Mineralogie, Geologie und Paläontologie, Abteilung B 75, 231-311.

KutsCHER, M. 1996. Echinodermata aus dem Ober-Toarcium und Aalenium Deutschlands II: Ophiuroidea. Stuttgarter Beiträge zur Naturkunde Serie B (Geologie und Paläontologie) 242, $1-33$.

LAMARCK, J.B. 1812. Extrait du cours de zoologie du Museum d'histoire naturelle sur les animaux sans vertebras. 127 pp. D'Hautel, Paris.

LinNeus, C. 1758. Systema naturce per regna tria naturce, secundum classes, ordines, genera, species, cum characteribus, differentiis, synonymis, locis. Tomus I. Editio decima, reformata. 824 pp. Salvius, Holmiæ.

Montagu, G. 1803. Testacea Britannica, or natural history of British shells, marine, land and the fresh-water, including the most minute: systematically arranged and embellished with figures. $606 \mathrm{pp}$. White, London.

DOI 10.5962/bhl.title.33927

MörCH, O.A.L. 1875. Synopsis molluscorum marinorum Indiarum occidentalium. Malakozoologische Blätter 22, $142-184$.

NütZEL, A. 2002a. An evaluation of the recently proposed Palaeozoic gastropod subclass Euomphalomorpha. Palaeontology 45, 259-266. DOI 10.1111/1475-4983.00236

Nützel, A. 2002b. The late Triassic species Cryptaulax bittneri (Mollusca: Gastropoda: Procerithiidae) and the Mesozoic marine revolution. Paläontologische Zeitschrift 76, 57-63.

NüTZEL, A. 2005. Recovery of gastropods in the Early Triassic. In BotTJER, D. \& GALl, J.-C. (eds) The biotic recovery from the end-Permian mass extinction. Comptes Rendus Palevol 4, 501-515. DOI 10.1016/j.crpv.2005.02.007

NüTZEL, A. 2010. A review of the Triassic gastropod genus Kittliconcha Bonarelli, 1927 - implications for the phylogeny of Caenogastropoda. Zitteliana 50, 9-24.

Nützel, A. \& ERwiN, D.H. 2004. Late Triassic (late Norian) gastropods from the Wallowa Terrane (Idaho, USA). Paläontologische Zeitschrift 78, 361-416.

Nützel, A. \& Kiessling, W. 1997. Gastropoden aus dem Amaltheenton (oberes Pliensbachium) von Kalchreuth. Geologische Blätter für Nordost-Bayern und angrenzende Gebiete 47, 381-414.

NÜtZel, A. \& Schulbert, C. 2005. Facies of two important Early Triassic gastropod lagerstätten: implications for diversity patterns in the aftermath of the end-Permian mass extinction. $\mathrm{Fa}$ cies 51, 495-515. DOI 10.1007/s10347-005-0074-5

NütZel, A. \& Senowbari-Daryan, B. 1999. Gastropods from the Upper Triassic (Norian-Rhaetian) Nayband Formation of central Iran. Beringeria 23, 93-132.

OrbignY, A. D' 1850. Prodrome de Paléontologie stratigraphique universelle des animaux mollusques et rayonnés 1. 394 pp. Masson, Paris. DOI 10.5962/bhl.title.62810

OrbignY, A. D’ 1851-1860. Paléontologie française. Terrains jurassiques. Tome II, Gastéropodes. 621 pp. Masson, Paris. 
Oschmann, W. 1994. Der Kimmeridge Clay von Yorkshire als Beispiel eines fossilen Sauerstoff-kontrollierten-Milieus. Beringeria 23, 93-132.

PChelintsev, V.F. \& KorobKov, I.A. 1960. Osnovy paleontologii, Molliuski - briukhonogie. 360 pp. Nauka, Moskva.

Perron, F.E. 1978. Seasonal burrowing behavior and ecology of Aporrhais occidentalis (Gastropoda: Strombacea). Biological Bulletin 154, 463-471. DOI 10.2307/1541072

PHILLIPS, J.P. 1829. Illustrations of the geology of Yorkshire; or, a description of the strata and organic remains of the Yorkshire Coast, part I. 129 pp. Wilson and Sons, York.

PondER, W.F. 1990. The anatomy and relationships of the Orbistellidae (Gastropoda: Heterobranchia). Journal of Molluscan Studies 56, 515-532. DOI 10.1093/mollus/56.4.515

QuenstedT, F.A. 1852. Handbuch der Petrefaktenkunde. 792 pp. Laupp, Tübingen. DOI 10.5962/bhl.title.15107

QuenstedT, F.A. 1856-1858. Der Jura. 842 pp. Laupp, Tübingen.

QuenstedT, F.A. 1881-1884. Petrefaktenkunde Deutschlands. Band 7. Gastropoden. 867 pp. Fues's, Leipzig.

RAFINESQUe, C.S. 1815. Analyse de la nature: ou Tableau de l'univers et des corps organisés. 224 pp. Aux dépens de l'auteur, Palerme.

Riegraf, W., Werner, G. \& Lörcher, F. 1984. Der Posidonienschiefer. Biostratigraphie, Fauna und Fazies des südwestdeutschen Untertoarciums (Lias ع). 195 pp. Encke, Stuttgart.

RöHL, H.-J. 1998. Hochauflösende palökologische und sedimentologische Untersuchungen im Posidonienschiefer (Lias epsilon) von SW-Deutschland. Tübinger geowissenschaftliche Arbeiten 47, 1-170.

Roy, K. 1994. Effects of the Mesozoic Marine Revolution on the taxonomic, morphologic, and biogeographic evolution of a group: aporrhaid gastropods during the Mesozoic. Paleobiology 20, 274-296.

Salvini-Plawen, L. von 1980. A reconsideration of systematics in the Mollusca (Phylogeny and higher classification). Malacologia 19(2), 249-278.

Schlegelmilch, R. 1973. Fossilien aus der Tongrube Mistelgau bei Bayreuth. Aufschluß 24, 382-388.

Schlosser, M. 1901. Die Fauna des Lias und Dogger in Franken und der Oberpfalz. Zeitschrift der Deutschen Geologischen Gesellschaft 4. Heft, 513-567.

SCHRÖDER, M. 1995. Frühontogenetische Schalen jurassischer und unterkretazischer Gastropoden aus Norddeutschland und Polen. Palaeontographica, Abteilung A 283, 1-95.

Schubert, S., Gründel, J. \& NütZel, A. 2008. Early Jurassic (Upper Pliensbachian) gastropods from the Herforder Liasmulde (Bielefeld, Northwest Germany). Paläontologische Zeitschrift 82, 17-30.

Schulbert, C. 2001. Die Ammonitenfauna und Stratigraphie der Tongrube Mistelgau bei Bayreuth (Oberfranken). Beihefte zu den Berichten der Naturwissenschaftlichen Gesellschaft Bayreuth 4, 1-182.

Schulbert, C. \& Nützel, A. 2009. Über die jurassische Gastropodenfauna der Tongrube Mistelgau bei Bayreuth. Berichte der Naturwissenschaftlichen Gesellschaft Bayreuth 28, 475-499.

Sieberer, R. 1907. Die Pleurotomarien des Schwäbischen Jura. Palaeontographica 54, 1-68.

Sowerby, J. 1812-1822. The Mineral Conchology of Great Britain, vol. 1-4. 383 pp. Meredith, London.

StoliczKa, F. 1861. Über die Gastropoden und Acephalen der Hierlatz-Schichten. Jahrbuch der Königlich-kaiserlichen geologischen Reichsanstalt 43, 157-206.

Swainson, W. 1840. A treatise on malacology or shells and shell-fish. 419 pp. Longman, London.

DOI 10.5962/bhl.title.8027

SzABó, J. 1980. Lower and Middle Jurassic gastropods from the Bakony Montains (Hungary). Part 2. Pleurotomariacea and Fissurellacea (Archaeogastropoda). Annales historiconaturales Musei nationalis Hungarici 72, 49-71.

SzABó, J. 1983. Lower and Middle Jurassic Gastropods from the Bakony Mountains (Hungary). Part 5. Supplement to Archaeogastropoda; Caenogastropoda. Annales historiconaturales Musei nationalis Hungarici 75, 27-46.

SzABó, J. 1984. Two new archaeogastropod genera from the Tethyan Liassic. Annales historico-naturales Musei nationalis Hungarici 76, 65-71.

SzABó, J. 2009. Gastropods of the Early Jurassic Hierlatz Limestone Formation; part 1: A revision of the type collections from Austrian and Hungarian localities. Fragmenta Palaeontologica Hungarica 26, 1-108.

SzABó, J. 2011. Corrections to three gastropod genera, established by Kutassy on Late Triassic type species from Dachstein Limestone localities of Budapest (Hungary). Neues Jahrbuch für Geologie und Paläontologie, Abhandlungen 261, 37-47. DOI 10.1127/0077-7749/2011/0145

TAte, R. 1869. Contributions to Jurassic Palaeontology. 1. Cryptaulax, a new Genus of Cerithiadae. The Annals and Magazine of Natural History 4, 417-419.

DOI 10.1080/00222936908696088

TATE, R. 1870. On the palaeontology of the Junction beds of the Lower and Middle Lias in Gloucestershire. Quarterly Journal of the Geological Society of London 26, 394-408.

DOI 10.1144/GSL.JGS.1870.026.01-02.36

Teichert, S. 2009. Die Paläoökologie von Coelodiscus minutus (Gastropoda). 57 pp. Diploma thesis, Friedrich-Alexander Universität Erlangen-Nürnberg, Erlangen, Germany.

Terquem, M.O. 1855. Paléontologie de l'étage inférieur de la formation Liasique de la Pronince de Luxembourg, Grand-Duché (Holland) et de Hettange du Departement de la Moselle. Mémoires de la Société géologique de France 2(5), 29, 245-279.

Terquem, O. \& Jourdy, E. 1871. Monographie de l'étage Bathonien dans le département de la Moselle. Mémoires de la Société géologique de France 9(2), 1-175.

Thiele, J. 1928. Revision des Systems der Hydrobiiden und Melaniiden. Zoologische Jahrbücher, Abteilung für Systematik, Ökologie und Geographie der Tiere 55, 351-402.

Tracey, S., Todd, J.A. \& ERwin, D.H. 1993. Mollusca: Gastropoda. The Fossil Record 2, 131-167. 
Troschel, F.H. 1852. Bericht über die Leistungen im Gebiete der Naturgeschichte der Mollusken während des Jahres 1851. Archiv für Naturgeschichte 18(2), 257-307.

WAlther, H. 1951. Jurassische Mikrofossilien, insbesondere Gastropoden, am Südrand des Hils. Paläontologische Zeitschrift 25, 35-106.

WARÉN, A. 1994. Systematic position and validity of Ebala Gray, 1847 (Ebalidae fam. n., Pyramidelloidea, Heterobranchia). Bolletino Malacologico 30, 203-210.

Wenz, W. 1938-1944. Gastropoda, Teil I. In Schindewolf, O.H. (ed.) Handbuch der Paläozoologie, vol. 6. 1639 pp. Borntraeger, Berlin.

WILD, R. 1971. Dorygnathus mistelgauensis n. sp., ein neuer Flugsaurier aus dem Lias Epsilon von Mistelgau (Fränkischer Jura). Geologische Blätter für Nordost-Bayern und angrenzende Gebiete 21, 178-195.
Willmann, R. 1989. Muscheln \& Schnecken der Nord- und Ostsee. 310 pp. Neumann-Neudamm, Melsungen.

ZiegleR, B. 1988. Führer durch das Museum am Löwentor. Stuttgarter Beiträge zur Naturkunde, Serie C 27, 1-100.

Ziegler, P.A. 1990. Geological Atlas of Western and Central Europe. 239 pp. Geological Society Publishing House, Bath.

ZIETEN, C.H. vON 1830-1833. Die Versteinerungen Württembergs oder naturgetreue Abbildungen der in den vollständigsten Sammlungen, namentlich der in dem Kabinett des Oberamts-Arzt D. Hartmann befindlichen Petrefacten, mit Angabe der Gebirgs-Formationen, in welchen dieselben vorkommen und der Fundorte. 102 pp. Verlag \& Lithographie der Expedition des Werkes unserer Zeit, Stuttgart.

Zittel, K.A. von 1895. Grundzüge der Paläontologie (Paläozoologie), Abteilung I, Invertebrata. 971 pp. Oldenburg, München \& Leipzig. 